\author{
Universidade de São Paulo \\ Faculdade de Arquitetura e Urbanismo
}

Francesca Alessandra Ferreira Angiolillo

Um Rio já partido: relações entre centro e subúrbio na obra de Lima Barreto

São Paulo

2020 
Francesca Alessandra Ferreira Angiolillo

\section{Um Rio já partido: relações entre centro e subúrbio na obra de Lima Barreto}

Exemplar revisado e alterado em relação à Versão Original, sob responsabilidade da autora e anuência do orientador

A Versão Original, em formato digital, ficará arquivada na Biblioteca da Faculdade

São Paulo, 2 de julho de 2020

Dissertação apresentada à Faculdade de Arquitetura e Urbanismo da Universidade de São Paulo para a obtenção do título de mestre

Área de concentração

Projeto, Espaço e Cultura

Orientador

Prof. Dr. Ricardo Marques de Azevedo 
Autorizo a reprodução e divulgação total ou parcial deste trabalho, por qualquer meio convencional ou eletrônico, para fins de estudo e pesquisa, desde que citada a fonte.

Catalogação na Publicação

Serviço Técnico de Biblioteca

Faculdade de Arquitetura e Urbanismo da Universidade de São Paulo

Angiolillo, Francesca

Um Rio já partido: relações entre centro e subúrbio na obra de Lima Barreto / Francesca Angiolillo; orientador

Ricardo Marques de Azevedo. - São Paulo, 2020.

$131 \mathrm{f}$.

Dissertação (Mestrado) - Faculdade de Arquitetura e Urbanismo da Universidade de São Paulo. Área de concentração: Projeto, Espaço e Cultura.

1. Lima Barreto. 2. Reforma Urbana. 3. Belle Époque. 4. Literatura. I. Azevedo, Ricardo Marques de, orient. II. Título. 


\section{Agradecimentos}

A produção acadêmica enfrenta momentos de provação enquanto esboço estas linhas num quarto frio em pleno verão de 2020, após enchentes calamitosas que repetem aquelas que, já na época de Lima Barreto, seriam evitáveis.

A cada momento que alguém liga seu computador e abre seus livros, aqui ou em qualquer outro lugar, em busca de conhecimento, em busca de fazer parte dessa conversa infinita que é o trabalho de quem lê e escreve, todos os esforços que se enfrentam fazem sentido. Que o diálogo possa continuar, contra a má-fé, a ignorância, o autoritarismo, a falta de incentivos.

Por isso, o primeiro agradecimento vai para aqueles que, antes de mim, estudaram Lima Barreto e, levando suas palavras livro a livro mais adiante, o colocaram no meu caminho.

Mais do que isso, todos os que me precederam pavimentaram o meu caminho.

Não seria possível nem mesmo começar a andar sem o trabalho criterioso de nomes que não tive a sorte de conhecer. Em primeiro lugar, para mim e para todos os que ainda virão, sem dúvida, Francisco de Assis Barbosa, pioneiro em abrir nossos olhos para Lima Barreto, ao organizar sua obra ficcional, seus diários, escrever sua primeira biografia, dando-lhe o lugar que não teve em vida. Inestimável ainda é a contribuição de Nicolau Sevcenko, que morreu tão precocemente. Sem Antonio Candido e Antonio Arnoni Prado, minha leitura teria sido mais pobre. Sem Beatriz Resende e Lilia Schwarcz, teria sido mesmo impossível.

Agradeço também ao meu orientador, Ricardo Marques de Azevedo, que desde a graduação acredita nas minhas ideias e que aceitou me acompanhar neste percurso mesmo antes de eu ter definido o projeto, ainda como aluna especial em sua disciplina.

Aos meus professores de todas as disciplinas que cursei, com os quais aprendi a ser rigorosa e renovei o amor por pensar as cidades, que julgava sepultado por duas décadas de outros interesses. Obrigada por isso, Fernanda Fernandes, Giselle Beiguelman, Leandro Medrano, Luís Antonio Jorge e Maria Cristina Silva Leme. 
Ganhei também colegas que se tornaram amigos e amigas. Vocês são muitos e não caberia nomear, mas sou grata, de coração, pela companhia na jornada.

Agradeço ainda à Ana Castro, que desde uma dessas sessões de seminário se firmou para mim como uma referência, lembrando-me sempre que aqui havia liberdade para ver a história das cidades sob o prisma da literatura, unindo paixões.

Aos meus chefes na Folha de S.Paulo, por compreenderem sem hesitação a necessidade dos períodos de afastamento para a escrita desta dissertação.

A todos os que me ouviram falar desse projeto, às vezes de maneira parca, às vezes com a ansiedade se sobrepondo à animação, na faculdade e no jornal, meu muito obrigada por me aguentarem e me apoiarem.

Aos meus amigos e amigas que acreditaram em mim, me dando ânimo quando eu não acreditava que fosse dar certo. Obrigada por isso, Daniela, Laura Juliana, Úrsula; à Francesca e ao Francesco, xarás e interlocutores; à Mariana, rainha da cartografia mental e dos tira-dúvidas transcontinentais. Além dela, Juliana Doretto, Haroldo Ceravolo Sereza, Magdiel Silva e Gleuson Pinheiro me socorreram quanto a questões de última hora.

À minha mãe, Inês, e ao meu marido, Aarón, meus agradecimentos infinitos. Sem o amparo e a compreensão de vocês eu não chegaria a estas linhas.

Mas, sobretudo, muito devo ao Julián, que, mesmo sem entender por que a mãe quis voltar a estudar, nunca me deixou esmorecer. A ele agradeço por ter dito que eu não devia desistir e por me dar a chave para abrir a última porta que faltava.

A você, filho amado, dedico esse trabalho - afinal de contas, ele fala sobre alguém que, enfrentando dificuldades incomensuravelmente maiores, nunca abriu mão do que queria e sentia que devia fazer.

Eis uma lição que você nasceu sabendo e que eu, com tudo isso, aprendi. 


\section{RESUMO}

ANGIOLILLO, Francesca. Um Rio já partido: relações entre centro e subúrbio na obra de Lima Barreto. 2020. 121 f. Dissertação (Mestrado em Arquitetura e Urbanismo) - Faculdade de Arquitetura e Urbanismo da Universidade de São Paulo, 2020

Esta pesquisa tem como tema as relações entre o centro e o subúrbio da cidade do Rio de Janeiro na obra de Lima Barreto (1881-1922), autor negro que viveu e escreveu sobre as principais mudanças do começo do século XX na capital do país, onde nasceu e morreu. No arco de sua vida, viu surgirem a Abolição e a República e presenciou a maior reformulação urbanística por que passou a cidade, iniciada sob os mandatos de Rodrigues Alves, presidente da República, e Pereira Passos, prefeito da capital federal. As reformas urbanas e seus efeitos foram acompanhadas em seus textos ao longo de quase 20 anos, até sua morte. $\mathrm{O}$ objeto de trabalho é a obra de Lima Barreto, tanto ficcional, com foco principal em romances selecionados, quanto não ficcional, em escritos na imprensa, privilegiando as crônicas, mas não se limitando a elas. Trata-se de compreender como a produção de um escritor que viveu entre as franjas da cidade e o centro do poder ajuda a iluminar a cisão que o Rio já então vivia e ainda vive.

Palavras-chave: Reforma urbanística. Belle Époque; Literatura. Lima Barreto 


\begin{abstract}
ANGIOLILLO, Francesca. Rio, a broken city: relations between center and suburbs in Lima Barreto's oeuvre. 2020. 121 f. Dissertação (Mestrado em Arquitetura e Urbanismo) Faculdade de Arquitetura e Urbanismo da Universidade de São Paulo, 2020

This research, "Rio, a broken city: relations between center and suburbs in Lima Barreto's oeuvre", has as its theme the relations between center and suburbs of Rio in the work of writer Lima Barreto (1881-1922), a black author who lived the and wrote about the main changes in Rio in the beginning of the 2oth century, when the city was Brazil's federal capital, city in which he lived and died. In his life span, he saw the end of enslavement abolition and the birth of the Republic. He also watched and wrote about the most important urban renovation that the city has undergone to the date, which started under Rodrigues Alves, Brazil's president, and Pereira Passos, Rio's mayor. He followed the urban renovation and its effects in his texts for almost 20 years, until his death. The object of this work is Lima Barreto's oeuvre, both ficcional, focusing on selected novels, and non fictional, based on his texts for the press. The main goal is to understand how the literary production of a writer who lived between the fringes of the city and center of political power can help enlightening the scission Rio already experienced then, and still does.
\end{abstract}

Palavras-chave: Urban renovation. Belle Epoque; Literature. Lima Barreto 


\section{Nota a respeito da revisão}

A presente versão deste trabalho contém revisões que foram feitas após a defesa, realizada em $1^{\circ}$ de junho de 2020. Na maior parte, as modificações foram feitas para corrigir problemas de acabamento que percebi em releituras, após o depósito da dissertação. Outras, porém, são alterações pontuais, decorrentes de contribuições feitas pelas integrantes da banca, Professora Doutora Beatriz Vieira de Resende, da Faculdade de Letras da UFRJ, e Professora Doutora Lilia Katri Moritz Schwarcz, da FFLCH-USP. Acréscimos e alterações decorrentes do profícuo diálogo que mantivemos durante o exame, pelo qual registro aqui minha gratidão, estarão devidamente assinalados em notas de rodapé ao longo do texto. 


\section{Sumário}

Introdução: por que Lima Barreto?

1.1. João e Amália, filhos de outro tempo 18

1.2. Lima, o excêntrico 28

1.3. Lima, o militante 48

1.4 O lugar da ficção 54

Capítulo 2: a nova vida no centro do poder 56

2.1. O ideário por trás das reformas

2.2. Cada cabeça, uma sentença: as duas reformas do centro 73

2.3. O vagar dos amanuenses 79

Capítulo 3: uma vida à margem 


\section{Introdução: por que Lima Barreto?}

Em que medida pode a visão de um escritor jogar nova luz sobre mudanças urbanas acerca das quais muito já se estudou e escreveu?

Mais particularmente, no que contribui a visão de um escritor das primeiras décadas do século 20 para o entendimento das reformas implementadas a fim de que a cidade deixasse para trás os tempos da Corte e se tornasse, de fato, a capital da República? Mais ainda, como pode uma obra literária iluminar as consequências de tais mudanças nas formas de viver a cidade?

O que de específico e próprio pode nos dizer esse escritor se ele for não um membro da classe dirigente; não um homem branco das altas esferas do poder ou a

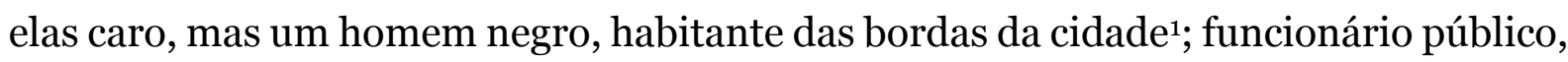
mas não dos altos escalões; um intelectual forjado na quietude de um quarto no subúrbio, sempre à parte nas instituições literárias do centro da cidade; um homem crítico dos rumos do poder e que se via deslocado do lugar que julgava merecer por força de sua situação social, morto aos 41 anos, vitimado pelo alcoolismo no qual buscou mitigar os efeitos dessa mesma situação?

\section{E se esse homem se chamar Lima Barreto?}

Este trabalho pretende ler, à luz da obra de Afonso Henriques de Lima Barreto, as relações entre centro e subúrbio no Rio de Janeiro e mostrar como, há mais de cem anos, aquela cidade já se partira. Se Zuenir Ventura, no seu celebrado livroreportagem, que acaba de completar 25 anos, traz os contrastes entre morro e asfalto, entre uma elite branca interligada e o cinturão de pobres que a observa e assombra, este trabalho se volta para outra cisão, ocorrida no princípio do século XX, a partir das obras de modernização da capital da República nascente, comandadas pelo prefeito Pereira Passos entre 1902 e 1906. A expulsão dos pobres do centro e a conformação dos subúrbios da zona norte com a transformação dos antigos arrabaldes em bairros

\footnotetext{
${ }^{1}$ Aqui em algumas poucas ocasiões, no texto original, empreguei o termo "periferia" como denominação genérica para os subúrbios do Rio à época de Lima Barreto; após a professora Lilia Schwarcz apontar, durante a banca, o anacronismo no uso desse termo, optei por substituí-lo.
} 
nobres da zona sul são o passo inicial para a divisão social projetada no espaço que, até hoje, perdura.

Ao longo desta dissertação deve ficar claro por que Lima Barreto, mais do que outros escritores de seu tempo, ocupou uma posição privilegiada para observar tais relações entre centro e subúrbio - conquanto "privilégio" pareça uma palavra estranha, uma noção muito distante da experiência de vida de Lima.

Sua posição à margem - que não se limita à geografia, mas que fica exposta pelo seu próprio trânsito diário do subúrbio ao centro, ao longo de anos trabalhando como amanuense na Secretaria da Guerra, na praça da República - contribui para fazer do escritor um observador singular da suburbanização que se consolida a partir das reformas urbanas do Rio de Janeiro.

Por sua pendularidade e por sua persistência em afirmar-se como um intelectual negro, ao mesmo tempo pertencente ao subúrbio e estranho a ele, frequentador do centro e estranho a ele, Lima Barreto é, mais do que qualquer contemporâneo seu, capaz de retratar o Rio como uma cidade, já então, partida.

A análise do lugar social do escritor e - tão importantes quanto este e mesmo dele decorrente - de seus lugares no espaço físico da cidade, assim como dos deslocamentos por eles implicados; os aspectos de sua formação que se imbricam com as expectativas ensejadas e não cumpridas; as frustrações e as críticas, vistas sob a perspectiva de alguém próximo o suficiente do poder, mas distante o bastante dos privilégios a ele associados; o vício, ou melhor, a doença; a expressão desse conjunto de aspectos num corpus literário marcadamente autobiográfico; e a validade desse corpus como objeto específico e valioso para entender o que se passava no Rio do começo do século XX - eis os principais tópicos que aqui se abordarão.

Sua visão do que sucedia à cidade, de como ela ia sendo apropriada pela elite, como nela se instalavam hábitos e costumes estrangeiros, as escolhas do poder pelo embelezamento e seus critérios, o contraponto no abandono dos subúrbios: todos esses são temas que se desprendem da produção de Lima Barreto. A relação com a rua é levada para a literatura, de ficção ou não ficção e, ao fazê-lo, o escritor busca encontrar a forma adequada para que sua obra chegue ao público, seja ele o leitor dos romances, seja aquele que compra o jornal ou a revista e neles lê suas crônicas. 
Em termos metodológicos, a pesquisa não parte da história da cidade para ir buscar na literatura os registros dos fatos, mas parte da cidade tal como aparece na obra de Lima Barreto, com toda a especificidade que sua posição pode propiciar, sendo cotejada e medida contra os acontecimentos de seu contexto histórico.

Ao mesmo tempo que trabalhava como amanuense e escrevia sua obra, Lima Barreto colaborou longamente com a imprensa - colaboração essa que se intensifica após sua precoce aposentadoria, no final de 1918, devido à saúde debilitada pelo alcoolismo, após menos de 15 anos de serviço público. Com a aposentadoria, também, o escritor passa a ter outra relação com a vida nos arredores de sua Vila Quilombo, apelido que daria a sua última casa, em Todos os Santos.

Escritos breves selecionados compõem, ao lado de romances escolhidos, o corpus da pesquisa, sendo estes últimos o fio condutor da análise. Entre os primeiros, privilegiaremos as crônicas, mas incluindo também suas "impressões de leitura", textos críticos nos quais, ao resenhar seus pares, traz inevitavelmente para o texto compreensão do mundo ao redor.

O primeiro capítulo tratará de inquirir sobre o lugar e os lugares de Lima Barreto. Serão abordados temas como sua presença no contexto, em contraponto a seus contemporâneos; sua inserção na esfera pública a partir de sua produção na imprensa; a questão racial; e a busca por uma literatura militante - ou seja, aspectos daquilo que se pode chamar seu lugar social.

Mas o capítulo 1 também se debruçará sobre os lugares físicos de Lima Barreto, a fim de compreender como os diferentes espaços que ocupa e frequenta na cidade contribuem para sua visão dessa cidade e para conformar a excepcionalidade — ou, de forma adequada, a excentricidade ${ }^{2}$ dessa visão.

Entre seus seis romances, destacam-se dois como centrais para o estudo, por serem aqueles em que a cidade fornece mais do que apenas um pano de fundo; neles, o espaço é determinante para a ação. Trata-se de Vida e morte de M. J. Gonzaga de Sá e Clara dos Anjos, nos quais centro e subúrbio são tematizados pelo escritor. Esses dois

\footnotetext{
2 Foi a professora Ana Claudia Scaglione Veiga de Castro quem sugeriu, durante o exame de qualificação, que a contribuição de Lima Barreto, mais do que excepcional, seria excêntrica. Embora não tenhamos aprofundado a sugestão na ocasião, compreendi o termo, com sua dupla conotação espacial e social, como uma chave de leitura para a posição do escritor no quadro em que se inscreve.
} 
livros articulam-se, em diferentes aspectos, com crônicas e contos que revisitam, sob outras vestes, assuntos similares ou circunstantes. Os capítulos 2 e 3 são dedicados à cidade que surge na obra literária de Lima Barreto, com ênfase na leitura desses dois romances.

No capítulo 2, o assunto é o centro, palco principal das reformas de Pereira Passos e Carlos Sampaio. A vida que ali se desenrola é em grande parte a do funcionalismo público, cujos quadros Lima Barreto integrou, não sem desgosto, o que alimentou sua literatura de várias formas. Vida e morte de M. J. Gonzaga de Sá destaca-se como a obra em que a cidade, em seu passado e presente, está no centro da trama. Esta é conduzida pelo narrador, o funcionário público Augusto Machado, em torno de seu convívio com o personagem do título, ele também funcionário, pautado pelas deambulações por uma cidade em mutação.

Vida e morte de M. J. Gonzaga de Sá (1919) é não só o romance que faz a elegia de uma cidade perdida; vale observar a relação intrínseca que com a cidade guarda o personagem-título, desde o nome: é um descendente de Estácio de Sá, fundador do Rio de Janeiro. Lê-lo é perceber a compreensão que tinha o escritor daquele mundo que ocupava durante o dia desde que, jovem de 18 anos incompletos, ingressa na Escola Politécnica, localizada no Largo de São Francisco, não muito distante da Praça da República, sede da repartição que anos mais tarde passaria a ser seu local de trabalho. Esse centro - com seus restos de casario sobreviventes às reformas, as ruas que ele palmilhava até a praia de Santa Luzia como faria Augusto Machado acompanhado do colega mais velho e sábio, Gonzaga de Sá - é ele próprio um personagem da obra, na qual o subúrbio está presente como contraponto.

A vida no centro do poder aparece também em outras narrativas longas, como Recordações do escrivão Isaías Caminha. Escrito em paralelo a Vida e morte de M. J. Gonzaga de Sá, esse romance à cleff foi escolhido por Lima Barreto para ser sua estreia literária e retrata em grande parte os meandros da imprensa. A comparação entre os dois romances contribui para compor, na pesquisa, o desenho que Lima Barreto faz do Rio como metrópole modernizada e símbolo de um poder.

Clara dos Anjos é o romance do subúrbio por excelência e é o objeto de análise central do terceiro capítulo. Se Vida e morte de M. J. Gonzaga de Sá, último romance que o autor viu publicado em vida, era considerado por ele sua obra mais bem-acabada, 
o livro que conta a história de Clara, mulata, suburbana, seduzida e abandonada é a obra que o acompanhou ao longo de toda a carreira. Suas anotações no Diário íntimo trazem desde 1904 esboços da obra. O conjunto resultante, publicado postumamente como folhetim, dista muito das intenções iniciais do autor; nele, contudo, fica clara a cisão ideológica que existe, desde então, entre centro e subúrbio. Fica nítida também a estratificação social dos subúrbios, que se manifesta no drama da jovem e humilde Clara, ludibriada por um malandro branco, filho de uma família com fumaças aristocráticas, morador de um bairro melhor.

Tanto no segundo quanto no terceiro capítulo, a análise se complementará com o cruzamento de ideias, figuras e tópicos apresentados por outros escritos. Não são poucas as crônicas em que Lima Barreto tratou tanto do centro quanto do subúrbio, e a diferença no enfoque dado aos temas segundo o gênero literário escolhido para tratálos é também digna de análise.

O estudo, evidentemente, não se dá somente com base na literatura de Lima Barreto. Muito se escreveu sobre o Rio da Belle Époque. A vasta bibliografia que aborda a vida na capital da República, os melhoramentos urbanos de Pereira Passos e a produção intelectual do período ampara portanto, de forma direta e indireta, o entendimento da obra de Lima Barreto. A lista a seguir é um repasse não exaustivo dos títulos que, ao lado de artigos e ensaios, fundamentam o presente estudo.

Sobre as reformas urbanas, O Rio de Janeiro de Pereira Passos, organizado por Giovanna Rosso Del Brenna, provê, além de iconografia e ensaios, uma cronologia dos melhoramentos conforme registrados na imprensa, em decretos e em discursos, constituindo assim obra de referência importante.

Jayme Larry Benchimol e André Nunes de Azevedo oferecem visões distantes no tempo e complementares sobre as renovações ocorridas entre 1902 e 1906, em Pereira Passos, um Haussmann tropical e A grande reforma urbana do Rio de Janeiro, respectivamente. A obra de Azevedo, além disso, provê uma rica leitura dos conceitos de civilização e progresso que embasa boa parte do capítulo 2.

Nicolau Sevcenko delineia o ambiente social e cultural do período em dois estudos que se fizeram clássicos. A Revolta da Vacina retrata, por meio da análise do episódio do título, a subjugação das camadas inferiores. Em Literatura como missão, 
incontornável em qualquer estudo sobre Lima Barreto, Sevcenko abordará a ideia de uma literatura imbuída de dever social e de um projeto de país.

Igualmente incontornável é a biografia de nosso autor traçada por Francisco de Assis Barbosa. A vida de Lima Barreto foi, por muitos anos, o mais completo relato biográfico do escritor, um trabalho minucioso feito pelo jornalista que também se tornou o organizador de suas obras completas, trabalho esse sem o qual não teria ocorrido a revalorização da obra de Lima. Recentemente, Barbosa ganhou a companhia da historiadora e antropóloga Lilia Moritz Schwarcz que, com Lima Barreto: triste visionário, contextualiza a obra do escritor no quadro mais amplo, colocando mais ênfase na questão racial e na importância de ele se colocar como um intelectual negro. Ambas as biografias servem de base para o entendimento detalhado de uma obra em muito calcada nas referências autobiográficas.

É importante, porém, também ouvir o autor falar de si, e nesse caso contamos com o valioso Diário íntimo, coligido por Francisco de Assis Barbosa, a partir de organização prévia feita por Evangelina Lima Barreto, irmã do escritor3, contendo não só relatos pessoais mas também esboços de obras.

Para o desenvolvimento de uma pesquisa que pretende encontrar as ressonâncias da tensão entre centro e subúrbio em um conjunto literário, é preciso, primeiro, compreender o que significa, no Rio, a categoria subúrbio.

O rapto ideológico da categoria subúrbio, do geógrafo Nelson da Nóbrega Fernandes, abre novos entendimentos sobre ideias preconcebidas acerca da relação entre centro e subúrbio no caso carioca, em que subúrbio deixa de significar simplesmente arrabalde para se tornar um local merecedor de pouca atenção pública no sentido da constituição da civilidade urbana4, à beira da linha do trem, onde vivem as classes populares, funcionários públicos, operários, pequenos comerciantes locais.

\footnotetext{
3 Agradeço à professora Lilia Schwarcz por assinalar a omissão do trabalho da irmã do escritor, na versão original deste texto. Ela própria a cita (SCHWARCZ, 2017, p. 11), de modo que esta não era uma informação para mim desconhecida. Graças à observação feita pela professora durante a banca, posso aqui corrigir o meu descuido quanto ao zelo que Evangelina dedicou à memória do irmão mais velho.

4 Originalmente, este trecho dizia que subúrbio passara a designar um "local destituído de um mínimo de civilidade urbana". Conquanto o subúrbio descrito por Lima Barreto muitas vezes seja de fato um local abandonado com relação a critérios de civilidade urbana - com ruas descuidadas, esburacadas, sem traçado regular ou oficial etc. - entendo que a expressão parecia imprecisa, conforme apontou, durante a banca, a professora Beatriz Resende.
} 
Se a obra de Nóbrega Fernandes ilumina certos aspectos subjacentes a Clara dos Anjos, de Lima Barreto, para bem analisar esse romance póstumo é preciso, ainda, conhecer como se constitui o gênero folhetim. Como a versão final do romance e a mais completa foi escrita para a publicação em entregas na revista Mundo Literário, o estudo de Folhetim, clássico de Marlyse Meyer, fundamenta a compreensão de como Clara dos Anjos se insere nesse gênero literário.

A imprensa, é evidente, tem também um papel importante nesta história. No caso dos textos publicados por Lima Barreto em jornais e revistas, foram usados os textos estabelecidos em edições recentes de crônicas e artigos. Foram utilizados os dois volumes de Toda crônica, organizados por Beatriz Resende e Rachel Valença; Sátiras e outras subversões, em que Felipe Botelho Corrêa reuniu textos publicados pelo escritor sob diferentes pseudônimos, muitos dos quais identificados na pesquisa para esse livro; e Impressões de leitura e outros textos críticos, em que Beatriz Resende coligiu escritos sobre teatro, literatura e cartas selecionadas do escritor.

Mas, sobretudo para o segundo capítulo, era importante compreender como as obras do centro da cidade foram recebidas pelos contemporâneos de Lima Barreto. $\mathrm{O}$ já citado O Rio de Janeiro de Pereira Passos traz uma valiosa seleta de trechos de textos que abordaram a reforma urbana, ano a ano, de 1902 a 1906. Essa seleção foi utilizada para as citações indiretas, além de servir como guia para que, sempre que possível e pertinente, localizássemos as fontes originais, utilizando-as para as citações diretas. Para esse fim, e para textos que extrapolam o período abordado no livro organizado por Giovanna Rosso del Brenna, utilizamos a Hemeroteca Digital da Biblioteca Nacional, na qual podem ser consultados os periódicos em versão facsimilar.

As considerações finais deverão dar conta de definir que cidade é essa que Lima Barreto nos oferece em seus escritos; como em sua obra aparecem a cisão, as relações e as tensões entre centro e subúrbio; e como e por que ler sua obra enriquece a compreensão do Rio de Janeiro nascido no começo do século 20 e, ainda hoje, tão infelizmente parecido ao que era um século atrás. 


\section{Capítulo 1: o lugar e os lugares de Lima Barreto}

A produção literária de Lima Barreto guarda uma intensa ligação com sua biografia; criação e experiência pessoal entretecem-se numa trama apertada em toda a sua obra. Os fatos vividos pelo autor carioca renderam páginas notáveis de escritos íntimos, observações transladadas para contos, crônicas e romances, ou diretamente da memória para a ficção e os textos jornalísticos.

Não se trata, aqui, de ir buscar os cruzamentos entre invenção e memória na obra de Lima Barreto; as coincidências, que nunca se esconderam muito, já foram vastamente repertoriadas em estudos acadêmicos, a começar pelo trabalho desenvolvido por Antonio Arnoni Prado em seu mestrado, depois publicado em livro (PRADO, 1976) - possivelmente o primeiro a registrar tais correspondências, como lembra Antonio Candido (2000, p. 44) - bem como em muitos outros, posteriores.

Trata-se de, perseguir na obra de Lima Barreto a ideia de "lugar", com o termo aqui entendido em sua acepção de localidade física mas também como posição social; trata-se de encontrar como os deslocamentos, no espaço e na sociedade, repercutem em sua criação literária. A análise desses deslocamentos permitirá estabelecer a especificidade - ou a excentricidade - do pensamento de Lima quando contraposto a seu contexto.

Os fragmentos literários selecionados para este capítulo servirão para balizar fatos biográficos também narrados sob o ponto de vista desses deslocamentos. É preciso para tal estabelecer os fatos que servirão como pontos de partida.

Para este fim, dependeremos em grande parte das biografias escritas pelo jornalista Francisco de Assis Barbosa e pela antropóloga e historiadora Lilia Moritz Schwarcz; a primeira, mais breve, foi lançada em 1952, 30 anos após a morte precoce do escritor, tendo contado, em sua elaboração, com a participação de pessoas que conviveram com o biografado - como seus três irmãos mais moços, Evangelina, Carlindo e Eliézer. A segunda, de 2017, alimenta-se de muitos estudos que só puderam florescer graças ao trabalho de Barbosa, que, além de biógrafo do escritor foi organizador, com Antonio Houaiss e Manuel Cavalcanti Proença, das Obras de Lima 
Barreto $^{5}$. Enquanto a primeira se abasteceu de fontes primárias até então inéditas como os documentos que os irmãos haviam preservado em um móvel na casa onde viviam -, a segunda cumpre oferece um quadro mais completo da época em que viveu Lima Barreto, com relação ao panorama histórico, político e intelectual.

A leitura de ambas as obras é assim, complementar e necessária. Não haveria, contudo, por que repassar todos os dados que Barbosa e Schwarz reuniram em cerca de mil páginas e muitos anos de esforços. Articularemos alguns aspectos biográficos reunidos em torno da já referida ideia de lugar.

Somam-se a essa base biográfica os escritos de Lima Barreto sobre si, reunidos no Diário íntimo (BARRETO, 1961), e trechos de ficção e não ficção do autor que possam iluminar as questões que se pretende cobrir neste trabalho.

\subsection{João e Amália, filhos de outro tempo}

É possível dizer que Lima Barreto viveu numa espécie de interregno; tanto no que diz respeito ao tempo - tendo visto, na infância, primeiro findar a escravidão e, em seguida, o Império - quanto no tocante ao espaço - vivendo em carne própria os deslocamentos entre centro e subúrbios impostos a uma grande parcela da população carioca.

Os ideais sob os quais cresceram os pais de Lima Barreto pressupunham uma trajetória diferente da que a família que formaram acabou tendo.

Nasceram, pai e mãe, de mulheres ex-escravizadas em relações com homens brancos. O pai, João Henriques, era filho de um madeireiro português da rua da Misericórdia, no centro do Rio, que nunca assumiu seu vínculo com Carlota Maria dos Anjos, alegando, como era comum, que o filho era fruto de uma relação fortuita (SCHWARCZ, 2017, 42).

5 Compreendendo a vasta gama de gêneros que Lima exerceu - diário, correspondências, resenhas literárias, crônicas e ficção -, essa coleção é muitas vezes referida como "obras completas" de Lima Barreto, embora textos inéditos em livro, contos e crônicas, tenham sido descobertos e publicados em volumes posteriores ao trabalho capitaneado por Francisco de Assis Barbosa, já no século XXI. 
A paternidade da mãe, Amália Augusta, é menos certeira - mas seu caso é também ele exemplar das relações inter-raciais no período. A mãe de Amália Augusta, Geraldina Leocádia, era “cria”, como diria o próprio Lima em seu Diário Íntimo (BARRETO, 1961, p. 131), da família Pereira de Carvalho, de São Gonçalo. O médico e alferes Manuel Feliciano, o patriarca, nunca assumiu a descendência gerada com Geraldina Leocádia, escrava alforriada nos anos 1840 pela família em cuja casa permaneceu; mas foi padrinho de Amália Augusta, laço que garantiu o sobrenome e a boa educação da menina, mesmo após a morte dele (SCHWARCZ, 2017, p. 37).

Nascida em 1862, Amália Augusta teve o apoio da família Pereira de Carvalho para estudar, tornando-se professora e, mais tarde, já casada com João Henriques, proprietária de uma escola para moças. Lilia Schwarcz (2017, p. 41) analisa sua opção profissional dentro do quadro histórico mais amplo.

\begin{abstract}
Libertos nascidos no Brasil eram considerados livres, mas não gozavam dos mesmos direitos dos cidadãos nascidos livres. [...] É provável que tenha sido essa a razão para que algumas famílias afro-brasileiras que gozavam, fazia algum tempo, da liberdade, e que haviam conhecido um processo de ascensão social, criassem formas de atuação que as diferenciavam dos libertos mais recentes. Amália, por exemplo, distante das atividades domésticas, escolhera o magistério. No Diario de Noticias de 26 de fevereiro de 1880 consta o certificado necessário: "Foram dispensadas das provas de capacidade profissional Amália Augusta Barreto [...] para que possa dirigir colégio de instrução primária e secundária e ensinar as respectivas matérias". Esse era um sonho agora possível de ser acalentado.
\end{abstract}

Em 1878, Amália Augusta se casaria, aos 16, com um frequentador do lar dos Pereiras de Carvalho, João Henriques de Lima Barreto, 25. O casal teve Afonso Celso de Assis Figueiredo, o visconde de Ouro Preto, como padrinho.

João Henriques, como sua mulher, nascera livre e acalentava o sonho de ascender socialmente. Queria ser médico, mas encontrou na carreira técnica um caminho mais adequado ao seu perfil. Fez estudos para se tornar tipógrafo e foi por meio da profissão que conheceu o futuro padrinho de seu casamento e de seu filho Afonso. Pouco após assumir a direção do jornal liberal A Reforma, em 1872, Afonso Celso contratou o tipógrafo. O político ainda não era ainda visconde de Ouro Preto, mas já fora senador e ministro; em 1882, se tornaria conselheiro do Estado; era pois um homem forte do Império, sendo próximo de dom Pedro II. O emprego no periódico 
era o segundo de João Henriques após ter se formado em seu ofício. Com as bênçãos do patrão no jornal, tornou-se em 1889 chefe das oficinas de composição da Imprensa Nacional, cargo do qual acabou exonerado, uma vez notado o pistolão - , por direito de antiguidade, a vaga cabia a outro funcionário. Ainda assim, progrediu no serviço público, destacando-se ao traduzir do francês e adaptar para as situações locais um manual de composição tipográfica. (SCHWARCZ, 2017, pp. 41-8).

Como assinala Lilia Schwarcz (2017, p. 49), João Henriques e Amália Augusta entraram para a vida adulta em uma sociedade na qual "conviviam padrões de sociabilidade mais aristocráticos com modelos burgueses e urbanos de inserção”. Se por um lado os pais de Lima Barreto tinham talento, por outro também recebiam "favor e proteção". "Carregavam, pois, méritos herdados dos dois sistemas: a ascensão burguesa com o protecionismo próprio de sociedades mais estamentais.”

Afonso Henriques de Lima Barreto nasceria a 13 de maio de 1881, com os pais já estabelecidos em Laranjeiras, um bairro de arrabalde muito procurado tanto por aristocratas que lá ergueram seus solares quanto por habitantes de origem muito mais modesta, em casas mais simples e cortiços, como os operários de fábricas e manufaturas da região, que ia ganhando então feições mais urbanas.

O primeiro filho sobrevivente do casal - que antes dele tivera Nicomendes, morto aos oito dias - , foi batizado unindo o primeiro nome do padrinho ${ }^{6}$ ao segundo nome do pai (SCHWARCZ, 2017). O difícil primeiro parto, dez meses após o casamento, afetara a saúde de Amália Augusta, dando início aos infortúnios da família - que, apesar disso, cresceria rapidamente; após Afonso, ainda chegariam Evangelina (1882), Carlindo (1884) e Eliézer (1886).

Além da paralisia nas pernas que a acometeu com o malfadado primeiro parto, Amália se descobriria tuberculosa; o sonho do magistério ficou definitivamente para trás. O diagnóstico levaria a família a mudar-se várias vezes. Perseguindo um tratamento então em voga, procuraram estar perto do mar, mudando-se para a rua Dois de Dezembro, no Flamengo e, para a rua das Marrecas, na Misericórdia, perto da praia de Santa Luzia e da Imprensa Nacional, onde trabalhava João Henriques.

6 Tinha por madrinha Nossa Senhora da Glória, santa de devoção de João Henriques (BARBOSA, 2017, p. 42). 
Mas a condição de Amália não melhorava. Procurando ares mais salubres e aluguel mais barato, foram para os subúrbios; primeiro para a localidade conhecida como Boca do Mato, depois para o Catumbi, mais próximo do centro do Rio, onde nasceria o quarto filho. Por fim, foram para Paula Matos, com ares de montanha. Nada adiantou. Amália Augusta de Lima Barreto morreu em dezembro de 1887, aos 25 anos. O filho mais velho, Afonso Henriques, tinha seis anos; o caçula, Eliézer, nem dois. A família retornaria para a região central.

Apesar da dificuldade, vem um período mais estável sem novas mudanças de endereço, com João Henriques progredindo no trabalho, enquanto os dois filhos mais velhos iniciavam-se nos estudos (SCHWARCZ, 2017, pp 54-8). Mas o baque e o deslocamento maiores estavam por vir.

Pouco depois da tão tardia Abolição - de cujos festejos Lima Barreto tomou parte, como uma inesperada comemoração de seus sete anos, que completava na data, rememorada na bela crônica "Maio" - , viria a República. Se ao se declarar extinta a escravidão faltava-lhe "o conhecimento direto da vexatória instituição, para lhe sentir os aspectos hediondos” (BARRETO, 2004, p. 78, vol. 1), recebeu o 15 de Novembro de 1889 de maneira mais concreta. Afinal, com a República viria a interrupção abrupta dos avanços do tipógrafo do Império.

Sem trabalho, João Henriques deixou os filhos aos cuidados dos Pereiras de Carvalho (BARBOSA, 2017, p. 57). Eis aqui as parcas, porém bem pouco líricas, lembranças de Afonso, recordadas, muito anos depois, em 1917 (BARRETO, 2004, p. 288, vol. 1).

Das festas por ocasião da passagem da Lei de 13 de Maio ainda tenho vivas recordações; mas da tal história da proclamação da República só me lembro que as patrulhas andavam, nas ruas, armadas de carabinas e meu pai foi, alguns dias depois, demitido do lugar que tinha.

E é só.

Poucos após o estabelecimento do novo regime, João Henriques viu-se obrigado a aceitar um emprego que nada tinha a ver com sua formação. Tornou-se escriturário das Colônias de Alienados da Ilha do Governador, onde se isolavam indivíduos que poderiam ser escolhos à ordem - não só os loucos, mas mendicantes, "vagabundos”, 
ex-escravizados que haviam quedado sem ocupação, sem lar e sem sustento na aurora da Abolição (SCHWARCZ, 2017, PP. 79-80).

A colocação, que o pai de Lima Barreto acreditava ser provisória, foi conseguida com a ajuda do ministro do Interior, Cesário Alvim, que fora cofundador de A Reforma ao lado de Afonso Celso e deixara o Partido Liberal às vésperas do golpe republicano. (SCHWARCZ, 2017, pp. 46, 79, 81)

A mudança a princípio dotou de ares de idílio os fins de semana do menino Afonso, matriculado em 1891 como estudante interno do Liceu Popular Niteroiense, tendo os custos arcados pelo visconde de Ouro Preto. João Henriques dedicou-se com afinco ao trabalho, sendo promovido a almoxarife em 1893, ano em que estouraria a Revolta da Armada. O episódio, no qual marinheiros se revoltaram contra o governo do marechal Floriano e invadiram a ilha do Governador, perturbaria o sossego rural em que a família vinha vivendo (BARBOSA, 2017, p. 51, 65-70). As consequências da invasão seriam lembradas por Lima Barreto na crônica “O Estrela”, publicada em 1916 no Almanaque d'A Noite.

A seleção de trechos a seguir, apesar de longa, mostra como um episódio histórico é vivido e tratado na prosa do escritor como acontecimento íntimo. O escrito faz uma síntese do período edênico - numa "velha habitação roceira”, em meio a um sítio com bambual e cajueiros, entre os quais o menino caçava filhotes de jacarés e aves - e de sua ruptura (BARRETO, 2004, pp. 259-62, vol. 1).

Cheguei em casa, como lhes contava, e logo tratei dos meus pássaros, dos meus laços, pouco se me dando com o duelo que se fazia de terra para o mar e do mar para a terra, a tiros de canhão e de carabina.

Meu pai, meu grande e infeliz pai, era dos funcionários da administração superior o único que tinha permanecido na ilha. O diretor, o médico, o escriturário se haviam retirado para a cidade.

\section{$[\ldots]$}

Estava eu assim descuidado quando, uma manhã, aí pelas oito horas, meu pai mandou-me chamar à Colônia de São Bento 7 , que ficava nas proximidades. Ele, meu pai, tomava café bem cedo e corria à Colônia para ver

\footnotetext{
7 Uma das que duas em que se reuniam os alienados da ilha (SCHWARCZ, 2017, p. 80).
} 
e superintender os serviços que lhe eram afetos, de modo que, às oito horas da manhã, já precisava mandar chamar-me ao estabelecimento.

Veio buscar-me o José da Costa, que ainda está vivo. Este José, ou antes, Zé da Costa, era nas Colônias tudo: cocheiro, carpinteiro, catraieiro e foi sempre doce e bom para mim.

Agora, com lágrimas nos olhos, lembro-me de quando, aos sábados, ia buscar-me no colégio, naqueles dias ansiosos e satisfeitos de minha meninice, isenta ainda de qualquer visão amarga do mundo e do desespero do meu próprio destino.

Zé da Costa não me disse qual o motivo do chamado e, ao chegar no sopé da colina em que se erguia o velho convento, bem em frente da ladeira que subia para a modesta capela sem fiéis, quase no centro da edificação, deparei armas ensarilhadas, uma porção de marinheiros e meu pai metido entre todo aquele apresto militar e guerreiro.

\section{$[\ldots]$}

Não me espantei e olhei tudo aquilo serenamente, tanto mais sereno quanto meu pai me parecia calmo e não correr perigo algum.

Hoje é que sinto bem de que forma malvada podiam interpretar aquela sua recepção e o motivo do meu chamamento.

Temendo que lhe fizessem qualquer violência, ele queria com a minha presença enternecer o comandante da força.

$[\ldots]$

Meu pai e o comandante da força subiram ao mosteiro

para tratar lá dos negócios que o interessavam.

Soube mais tarde que se tratou no momento de passar o Senhor Comandante Eliézer recibo dos objetos que ele queria retirar das Colônias: roupas, gêneros, medicamentos, etc.

\section{$[\ldots]$}

Desceram, meu pai e o comandante. De repente, eu vejo ser tirado do curral o "Estrela", um velho boi de carro, negro, com uma mancha branca na testa. o "Estrela" fazia junta com o "Moreno", um outro boi negro; e ambos, além de carreiros, lavravam também.

Foi o boi conduzido para junto da estrebaria e vi que um marinheiro, de machado em punho, o enfrentava e ia desfechar-lhe um golpe na cabeça.

Tive a visão rápida dos seus serviços e dos seus préstimos, pois era de ver a paciência, a resignação do "Estrela", quando, atrelado com o seu companheiro de junta, cavavam, com auxílio do arado, na encosta íngreme do morro, por detrás do convento, fundos sulcos que iam receber as manivas dos aipins e a rama da batata-doce.

A vista era daí soberba - toda a parte anterior da Guanabara, o Corcovado, as fortalezas, o zimbório da Candelária, a barra, o mar sem fim, a cidade inteira entre verdura e dourada pelo sol do poente...

"Estrela”, porém, não via nada daquilo. Sob o aguilhão do condutor, cavava resignadamente, docemente, tristemente, os sulcos no barro duro, para fazer render mais as sementes que a terra ia receber. 
Quando vi que o iam matar, não me despedi de ninguém. Corri para casa, sem olhar para trás ${ }^{8}$.

Apreendem-se, em “O Estrela” camadas distintas de informação quanto ao lugar e a situação da família Lima Barreto. O paraíso rural onde viviam, ao qual o menino voltava aos sábados, até o dia retratado na crônica era um lugar blindado do mundo. Ainda que consciente da Revolta da Armada - em uma carta enviada ao pai do colégio, o menino de 12 anos pedia que fossem buscá-lo, se possível, e dizia que as granadas estouravam por toda parte mesmo em Niterói (apud BARBOSA, 2017, p. 72) ${ }^{9}$, Afonso ali tinha seu refúgio, entre frutas e arapucas.

O trecho selecionado condensa também sutilezas sobre a vida da família nas colônias. Aprendemos que havia um faz-tudo que, com o pai de Afonso e os alienados, ficou para trás na debandada dos outros representantes do poder público. Que João Henriques, funcionário exemplar que era, em meio ao caos da revolta, se agarra à ordem, fazendo com que o comandante firmasse recibo da propriedade do Estado que estava expropriando.

Mas, além da descrição desse paraíso rural perturbado pelos tumultos da República nascente, aprendemos como do local se descortina "a cidade inteira", paisagem que o boi Estrela não via enquanto trabalhava. Da lírica descrição da vista, recordada por um Lima já adulto e distante daquela "meninice, isenta ainda de qualquer visão amarga do mundo”, desprendem-se significados secundários.

Alheios à paisagem, trabalham de forma inexorável os dois bois atrelados ao arado, fazendo "render", para quem pode erguer a cabeça e ver a vista, o seu trabalho. Ambos são pretos; note-se ainda que o segundo era chamado "Moreno". O adjetivo entra na lista de termos que compunham, segundo Lilia Schwarcz, uma "linguagem das cores" a expressar diferenças raciais, da qual em seus escritos Lima Barreto "abusa, como se guardasse o propósito de chocar" (2017, p. 417).

\footnotetext{
${ }^{8}$ Nesta e em outras citações de textos publicados anteriormente ao Acordo Ortográfico de 1990, que entrou em vigor no Brasil em 2009, a grafia foi atualizada, sem que tenham sido feitas outras correções, como de pontuação, por exemplo.

9 O biógrafo informa que a carta é de 28.set 1893 e diz que se encontra na Coleção Lima Barreto da seção de Manuscritos da Biblioteca Nacional, além de ter sido coligida nas Obras de Lima Barreto, em dois volumes ainda não reeditados. Lilia Schwarcz, citando a mesma missiva também a partir de Barbosa, diz não a ter encontrado nos manuscritos.
} 
Não é descabido dizer que a lembrança remete metaforicamente ao trabalho dos escravos, aos antecedentes do menino que tinha na ilha um bastião de liberdade. Na época em que escreve a crônica "O Estrela”, em 1916, a questão racial se havia configurado já como tema de Lima Barreto. O deslocamento social representado pela negritude se manifestaria, ao longo dos anos entre a "meninice" e a vida de adulto, em diapasões variados.

A partir do episódio da Revolta da Armada, a ilha recobraria a paz. O dedicado João Henriques seria promovido, em 1894, a administrador das colônias (SCHWARCZ, 2017, p. 105). Afonso seguia nos seus estudos; deixando o internato, foi morar numa pensão no centro do Rio, dividindo quarto com um menino italiano, Nicolao Ciancio, "tão pobre como ele". Por ali ficavam teatros e salas de cinema, além de cafés e livrarias da rua do Ouvidor e arredores, os quais mais tarde Lima conheceria melhor. Datam também dessa época os contatos do jovem estudante com a doutrina positivista, que mais tarde rejeitaria, e seu interesse pela filosofia de modo geral. Faz no colégio Paula Freitas os preparatórios para ingressar na Escola Politécnica, em 1897. Aos 15, estudaria engenharia civil, perseguindo o desejo de seu pai de ter um filho doutor (SCHWARCZ, 2017, pp. 111-9).

Mas não. Interessado em debates envolvendo questões sociais e história, era um aluno sem grande brilho nas ciências exatas, apesar dos esforços, e foi acumulando reprovações. Dava-se melhor com o antipositivista Oto de Alencar, matemático afeito à música e à filosofia, e saiu-se especialmente mal nas mãos de Licínio Cardoso, professor implacável - e feroz adepto do positivismo, doutrina da qual já então o aluno zombava nas rodas estudantis. Além do mais, Afonso tinha convicção de estar sendo reprovado graças ao fato de ser pobre e negro. Tentaria por anos se ajustar à expectativa do pai e a um meio mais branco e mais endinheirado que o seu (BARBOSA, 94-5 e 107-8; SCHWARCZ, 2017, pp. 120-4).

É certo que, também na Politécnica, formou seu grupo de amigos; integrou a nascente Federação de Estudantes do Brasil, que mais tarde abandonaria por ter a liga defendido o serviço militar obrigatório, e começou a escrever no periódico dos alunos da Politécnica, A Lanterna, levado pelo brincalhão Bastos Tigre (SCHWARCZ, 2017, pp. 124-5).

Mas em 1902 um acontecimento definiria seu rumo. 
“Foi no ano de 1902, pela festa de Nossa Senhora da Glória, que João Henriques enlouqueceu. A doença chegou de repente, sem avisar, como os raios em céu de abril”, escreve Francisco de Assis Barbosa (2017, p. 119).

João Henriques foi se deitar e acordou aos gritos, delirando, durante a noite. No dia seguinte, era outro. Desconfiado, repetia que não deixassem que a polícia o pegasse - estava obcecado por um erro que encontrara nas contas das colônias e temia ser acusado do desfalque que, por certo, não era obra sua. Por orientação médica, requereu e obteve uma licença em outubro de 1902; a família então se mudaria para o subúrbio do Engenho Novo. (BARBOSA, 2017, pp. 120-2).

A situação recaiu sobre Afonso, feito subitamente chefe da família que, além do pai e dos três irmãos, somava também a negra Prisciliana, primeiro criada da casa e já então companheira do pai, os três filhos desta e Manuel de Oliveira, ex-escravo que se fizera agregado da família nas colônias da Ilha do Governador, por quem aliás Lima Barreto demonstraria sempre enorme estima ${ }^{10}$ (BARBOSA, 2017, p.122).

De nada serviu que uma devassa feita pelo gabinete de J.J. Seabra, ministro da Justiça do recém-empossado governo Rodrigues Alves, atestasse a probidade do administrador das colônias; João Henriques nunca se recuperou. Sua aposentadoria foi requerida, sendo concedida por decreto somente em março de 1903. O cálculo e concessão dos vencimentos ainda tardariam meses, demora atribuída por Lima ao chefe da diretoria de Justiça, Pelino Guedes - o burocrata ganharia para sempre a inimizade do escritor e seria repetidas vezes retratado pela sua pena com as tintas do ridículo (BARBOSA, 2017, pp.122-5).

A necessidade pôs fim ao futuro que João Henriques acalentara para o filho; Afonso deixaria a Politécnica. Em 1903, sem outra saída, prestou concurso para amanuense da Secretaria da Guerra, tornando-se ele também funcionário público.

Nesse estágio da vida, aos 22 anos, Afonso Henriques de Lima Barreto deixava de galgar o patamar adicional da escalada que seus pais, ainda sob o Segundo Reinado,

${ }^{10}$ Manuel de Oliveira morreu a 8 de novembro de 1916, como registrou Lima em seu diário, dizendo que haveria de "escrever-lhe um artigo" (BARRETO, 1961, p. 183).O escritor de fato o recordaria com ternura em uma crônica, publicada a $1^{\circ}$ de maio de 1921 na Revista Souza Cruz (BARRETO, 2004, pp.361-3, vol. 2) 
previram para si e para sua descendência; uma escalada que podia ser vencida com estudo e com as ajudas certas, apagando as origens que ambos tinham.

Em vez de obter a ascensão social que o faria menos negro, a partir dali, Lima Barreto teve seu futuro carimbado com os estigmas que a ciência insistia em atribuir a essas origens. A história de sua família se via marcada por males que eram, então, atribuídos à raça e à miscigenação: a tuberculose de Amália Augusta; a neurastenia de João Henriques; e o vício no álcool, ao qual o pai sucumbira e que, mais tarde, seria também a doença de Lima Barreto ${ }^{11}$.

As circunstâncias implicariam mais um deslocamento. Os 200 mil-réis do salário do novo emprego, iniciado em 28 de outubro de 1903, davam para sustentar a família, mas a custo de escolherem uma morada mais modesta. O destino foi uma casa alugada em Todos os Santos, um subúrbio mais distante do centro, o qual Lima continuaria a frequentar, tomando o trem diariamente, para ir ao trabalho (SCHWARCZ, 2017, pp. 144-5).

Para Lilia Schwarcz, a pendularidade faria da literatura de Lima Barreto "uma ‘obra em trânsito', literalmente”, em que não se plasmavam "imagens chapadas”, mas reflexos ambivalentes dos territórios que frequenta (2017, p. 164).

\begin{abstract}
Em alguns escritos, sua vizinhança representa a pureza ainda não conspurcada pela civilização artificial da cidade do Rio; em outros, os subúrbios não passam de lugares com hábitos atrasados, pouco preparados para uma nova modernidade urbana. E a mesma ambivalência é demonstrada nos textos sobre a cidade; tida por Lima como um local de práticas estrangeiradas e importadas, é ao mesmo tempo o espaço para seu projeto de sucesso na literatura e de melancolia em relação ao funcionalismo público.
\end{abstract}

Enquanto o filho mais velho ia e vinha, "no silêncio da habitação suburbana", João Henriques se deixaria ficar, "sentado numa cadeira dias inteiros, sem falar e sem comer”, conforme escreve Francisco de Assis Barbosa (2017, p. 129):

${ }^{11}$ Tanto Schwarcz $(2017$, p. 157) quanto Barbosa $(2017,126)$ assinalam que dataria desta época o início do recurso à bebida por parte do escritor. 
Mas, de quando em quando, o delírio se apossava dele, e o pobre homem clamava pelo filho, aos gritos, como se Lima Barreto fosse a única pessoa capaz de protegê-lo em meio ao pavor que tinha de ser preso:

- Afonso! Afonso Barreto! Querem-me matar! Querem-me matar!

Os gritos reboavam morro abaixo, sacudindo a quietude suburbana. E por isso o povo da redondeza deu de chamar "a casa do louco" à pequena morada no alto da Rua Boa Vista, em Todos os Santos. ${ }^{12}$

\subsection{Lima, o excêntrico ${ }^{13}$}

Bem antes de se tornarem pais do jovem Afonso, Amália Augusta e João Henriques já haviam escutado a loucura rondar o umbral de seu lar. Pouco antes do casamento, o noivo teve aquilo que mais tarde seria diagnosticado "como um primeiro surto psicótico”. Na ocasião, tenso por ter tido uma promoção negada, preocupado sobre sua capacidade de manter os padrões que Amália Augusta tivera junto aos Pereiras de Carvalho, atormentado por ideias fixas, acabou passando uma temporada em uma casa de saúde no Catete e em seguida outra na cidade mineira de Caxambu (SCHWARCZ, 2017, p. 51).

Na década de 1870, quando os jovens João e Amália eram noivos, o campo do conhecimento encontrava-se em um momento de redefinição.

Entre os principais eventos a propelir esse rearranjo estava a Teoria da Evolução de Darwin, a qual, segundo escreve Nicolau Sevcenko, por sua "acessibilidade elementar", acabou "vulgarizada como uma teoria geral do comportamento e da ação

${ }^{12}$ A rua Boa Vista passou mais tarde a se chamar Elisa de Albuquerque; a casa ficava no número 76 (BARBOSA, 2017, p. 129). A numeração da via mudou; o 76 não fica mais no alto da rua, de modo que não é mais possível localizar o ponto exato onde ficava a "casa do louco".

13 Durante a defesa, a professora Lilia Schwarcz questionou o uso do adjetivo "excêntrico" para definir a posição de Lima Barreto com relação a seu contexto, argumentando que, possivelmente, seria mais adequado dizer que ele era "do contra", como um negro que, tendo ascendido, se sente deslocado. Embora concorde com a percepção, apego-me à riqueza de conotações do termo "excêntrico" para sustentar sua manutenção neste contexto. $\mathrm{O}$ termo foi escolhido diante da necessidade de rebater o rótulo de "marginal" que algumas vezes é erroneamente atribuído ao escritor e que também carrega uma conotação com respeito ao espaço físico; com o emprego da palavra "excêntrico", não quero dizer que Lima Barreto fosse extravagante, bizarro ou exótico, definições que, no uso comum, se aplicam ao termo, e sim que seu modo de pensar não validava o centro de um conjunto de ideias no qual se inseria; orbitava, pelo ganha-pão, o centro do poder, mas não fazia parte realmente do sistema que o sustentava; e, ao mesmo tempo, em termos físicos, vivia fora do centro. 
humana (darwinismo social, struggle for life), tornando-se o credo por excelência da Belle Époque" (2003, p. 100).

Eis como a biógrafa de Lima Barreto insere na narrativa a respeito dos pais do escritor o tema do determinismo (SCHWARCZ, 2017, pp. 51-2):

\begin{abstract}
Era como se eles [Amália e João], na contramão de seus sentimentos e intenções mais arraigados, acabassem por involuntariamente comprovar diversas teorias que começavam a entrar em voga nessa sociedade que se preparava para a abolição definitiva do cativeiro. O mesmo momento que anunciou novos modelos de liberdade foi justamente aquele que engendrou o surgimento de uma série de teorias deterministas e raciais [...]. Segundo elas, negros e sobretudo populações mestiçadas eram mais propensos à manifestação de doenças marcadas pela hereditariedade, como a criminalidade, a loucura, a tuberculose, a epilepsia. Esses seriam estigmas externos a atestar a existência de uma degeneração formativa e racial que incidia sobre esses grupos.
\end{abstract}

O jovem Afonso, filho de uma tísica e de um louco que além do mais era propenso ao álcool não se mostraria disposto a rezar pelo credo dessas que eram conhecidas como "teorias do coletivo" (SCHWARCZ, 2017, p. 52). Ao longo de sua trajetória, se chocaria contra essa e várias outras ideias prevalentes em sua época.

Em Literatura como missão, Nicolau Sevcenko analisa o contexto intelectual da Belle Époque, contexto esse no qual ele destaca, pela variedade de temas cobertos e pela excepcionalidade do tratamento, as obras de Euclides da Cunha e Lima Barreto. Na obra de Lima, escreve o historiador, tudo se une em "um imenso mosaico, rude e turbulento, que despoja a Belle Époque de seus atavios de opulência e frivolidade" (2003, p. 191). O escritor, diz ainda Sevcenko, tinha "visão extremamente clara dos limites e das propriedades do saber humano, e em particular do grande mito do seu tempo - a ciência"; rejeitando "a priori qualquer interpretação determinista ou naturalista, de base animista, que pretenda descortinar no comportamento humano ou nos processos históricos a ação de leis naturais imponderáveis” (2003, p. 193).

Sevcenko amarra a multiplicidade de temas da obra de Lima sob o critério do poder, “compreendido numa acepção bastante particular". Poder é tudo o que limita o pensamento e a inserção social. Essa acepção de poder inclui (2003, p. 201) 
desde as estruturas políticas propriamente, como o governo e as ideologias, às instituições culturais mais salientes, como a imprensa e a ciência, aos modelos formalizados de comportamento coletivo, como o cosmopolitismo e o bovarismo até as minúcias do relacionamento cotidiano, em que os símbolos de distinção definem sentidos de mando e subserviência ao nível do trato banal.

O breve apanhado feito pelo historiador no trecho acima mostra que Lima se opôs não só ao credo da ciência mas também a muitos outros aspectos vigentes no discurso dos grupos dominantes - os doutores, os políticos e os jornalistas. Grupos entre os quais muitos eram, também, escritores e com os quais Lima Barreto estreitaria o convívio na vida adulta, convertendo-os em alvos na sua carreira nas letras, que começaria a ganhar ímpeto depois de ele ter deixado a Escola Politécnica.

Nos primeiros anos como funcionário, Lima Barreto procuraria se aproximar do círculo interior do poder. De fato, ao longo de praticamente toda sua trajetória, oscilaria a respeito da posição que queria ocupar e que lhe seria vedada.

Ao mesmo tempo que Sevcenko escreveria sua tese de doutoramento, defendida em 1981 e depois publicada sob o título de Literatura como missão, o crítico uruguaio Ángel Rama trabalhava em um dos mais influentes títulos acerca das relações que uniam poder e classe intelectual nas sociedades latino-americanas. Escreve Rama (1985, p. 43, grifo do autor):

No centro de toda cidade [...] houve uma cidade letrada, que compunha o anel protetor do poder e o executor de suas ordens: uma plêiade de religiosos, administradores, educadores, profissionais, escritores e múltiplos servidores intelectuais. Todos os que manejavam a pena estavam estreitamente associados às funções do poder [...].

Rama observará que os membros da cidade letrada não só “servem a um poder como também são donos de um poder" (1985, p. 48). A profissão de um amanuense, é oportuno notar, consistia não propriamente em produzir, mas em transmitir as palavras do poder ${ }^{14}$. Pode-se dizer que Lima Barreto, assim, podia estar até dentro da cidade das letras - mas situado bem perto da porta.

\footnotetext{
$14 \mathrm{O}$ termo amanuense vem do latim $a b$ manu, à mão. Vulgarmente a ocupação é identificada como como "copista" apesar de o ofício envolver também redação de textos legais, e não só cópia, conforme explica Lilia Schwarcz (2017, p. 143).
} 
Até porque mesmo esse seu lugar, obtido por concurso público, fato de que se orgulhava ${ }^{15}$, lhe seria negado simbolicamente. O escritor registra em seu diário um caso ocorrido nos corredores da Secretaria da Guerra a 26 de dezembro de 1904 (BARRETO, 1961, pp. 51-2).

Hoje, comigo, deu-se um caso que, por repetido, mereceu-me reparo. Ia eu pelo corredor afora, daqui do Ministério, e um soldado dirigiu-se a mim, inquirindome se era contínuo. Ora, sendo a terceira vez, a cousa feriu-me um tanto a vaidade, e foi preciso tomar-me de muito sangue frio para que não desmentisse com azedume. Eles, variada gente simples, insistem em tomar-me como tal, e nisso creio ver um formal desmentido ao professor Broca (de memória). Parece-me que esse homem afirma que a educação embeleza, dá, enfim, outro ar à fisionomia.

Porque então essa gente continua a me querer contínuo, porque?

Porque... o que é verdade na raça branca, não é extensivo ao resto; eu, mulato ou negro, como queiram, estou condenado a ser sempre tomado por contínuo. Entretanto, não me agasto, minha vida será sempre cheia desse desgosto e ele far-me-á grande.

Era de perguntar se o Argolo [ministro da Guerra], vestido assim como eu ando, não seria tomado por contínuo; seria, mas quem o tomasse teria razão, mesmo porque ele é branco.

Quando me julgo - nada valho; quando me comparo, sou grande.

Enorme consolo.

Como se vê, novamente, o "mulato ou negro, como queiram" tinha lugar determinado na sociedade, e Lima o sabia. Há no Diário íntimo várias outras ponderações sobre a situação dos negros; por exemplo, numa mesma entrada, a 10 de janeiro de 1905, narra dois casos (BARRETO, 1961, pp. 81-2).

O primeiro é o de Vital, que teria conquistado o título de major honorário após ter lutado no Paraguai. Esse "pretinho, fulá, magrinho, de crânio deprimido, pele de sapato velho que nunca foi engraxado", como o descreve o jovem amanuense, perde o

$15 \mathrm{O}$ concurso era para apenas uma vaga. Os exames duraram oito dias, com provas de português, francês, inglês, aritmética, álgebra, geometria, geografia, história, direito, redação oficial e caligrafia. Lima terminou em segundo lugar, pois tinha péssima letra. Logo após o certame, porém, um funcionário da secretaria morreu, abrindo-se outro posto. Foi por muita insistência do amigo Mário Tibúrcio Gomes Carneiro que o futuro escritor se animou a ir requerer sua colocação. Ele não acreditava que a administração pública fosse tão correta a ponto de respeitar o concurso. Mas foi. (BARBOSA, 2017, p. 128) 
cargo no Arsenal de Guerra e os benefícios da carreira militar quando a burocracia decide que o verdadeiro major não seria ele, mas um branco de mesmo nome. Lima escreve que não tem certeza de que Vital fosse “o verdadeiro major”, mas julgava "que a ele competiam as honras; pobre e obscuro, ele precisava qualquer cousa para disfarçar isso, e ainda mais negro...”.

O segundo diz respeito à nomeação “do Hemetério (é um negro)” para professor do Colégio Militar ${ }^{16}$, que, contou-lhe um colega, "foi sustada na gaveta por ordem do Lauro Sodré", senador e um dos líderes republicanos, fato que Lima não deixa passar impune: "É singular que, fazendo eles a República, ela não a fosse de tal forma liberal, que pudesse dar um lugar de professor a um negro". E conclui: "É singular essa República”.

Eis outra vez a clareza de que há lugares sociais vedados a negros - o de funcionário, ainda que tenha conquistado seu lugar após concurso, e não por pistolão, como era tão comum; o do militar com mérito reconhecido; o de professor.

Nesse mesmo 1905, Lima faz seu primeiro ensaio no jornalismo profissional ${ }^{17}$ - ainda que de forma anônima. A partir de 28 de abril daquele ano, começaria a publicar no Correio da Manhã a série de colunas intitulada "O subterrâneo do morro do Castelo" - um "híbrido entre folhetim e reportagem”, na definição que lhe dá Frederico Coelho (2017c, p. 9).

Em 1907, jogando o jogo da época, em que estar nas páginas de jornais e revistas era um passo para participar ativamente dos círculos letrados, aceita o convite feito pelo jornalista e poeta simbolista Mário Pederneiras, cofundador da recém-criada FonFon, para figurar nos quadros da revista semanal como secretário de Redação. Lima tinha conquistado certa fama com os textos sobre o morro do Castelo, e Pederneiras argumentou que era a hora de deixar a "imprensa burguesa" - referindo-se a jornais

\footnotetext{
${ }^{16} \mathrm{O}$ maranhense Hemetério José dos Santos foi um intelectual negro e nome bastante atuante contra o racismo em sua época. Em 1889, foi feito adjunto de língua portuguesa do Colégio Militar; Lima talvez se referisse a uma promoção negada, ou de um fato anterior, depois revertido. Não foi possível esclarecer (SILVA, 2014, p. 4).

${ }^{17}$ Antes já havia colaborado, como mencionamos mais acima, para o jornal da Politécnica, A Lanterna; escreveria também para outras pequenas publicações do mesmo tipo e, além disso, faria uma tentativa na Revista da Época, fundada por um amigo também da Politécnica, Carlos Viana. Como conta Francisco de Assis Barbosa (2017, p. 141) a tentativa malogrou porque Lima não se permitiria escrever artigos louvando políticos, como exigia o cargo na publicação de Viana, mesmo que anonimamente.
} 
já estabelecidos, como o Correio da Manhã (SCHWARCZ, 2017, pp.191-2). Lima tinha consciência clara da chancela dada pela imprensa àqueles que alimentavam pretensões literárias, chancela essa que aparece muitas vezes em toda sua obra e que, então, era já criticada entre amigos.

Sua trajetória na revista durou apenas três meses, durante os quais publicou textos assinados sob pseudônimo. $\mathrm{O}$ expediente era comum, permitindo a publicações como a Fon-Fon simularem um grande número de colaboradores e criarem assim uma sensação de diversidade. Nem sempre porém os nomes adotados mascaravam bem o autor. Esse seria o caso com Lima Barreto, segundo escreve Felipe Botelho Corrêa no esclarecedor ensaio introdutório à reunião que organizou de crônicas do autor publicadas sob pseudônimos, muitos dos quais identificados pela primeira vez nessa ocasião (CORRÊA, 2016, pp. 16-9).

Embora brevíssima, a experiência na Fon-Fon fez com que Lima visse nas revistas um caminho literário para atingir um público em grande escala, uma vez que atingiam circulação nacional, bem maior do que a dos jornais da "imprensa burguesa". Se bem não fossem novidade no panorama editorial, as revistas ilustradas ganhavam espaço, impulsionadas pelo crescimento da malha ferroviária e a abundância de anunciantes dos grandes centros urbanos e seriam de fato veículo para a maior parte da produção do autor, que publicou a maior parte de seus textos na imprensa antes de tê-los editados como livros, na maior parte, póstumos (BARRETO, 2016, pp. 19-20).

Para Corrêa, "fica claro que Lima Barreto tomou as revistas como meios potentes para disseminar sua voz crítica e dissonante".

Seus numerosos textos tiveram um importante papel no desenvolvimento de uma fácil comunicação com a sociedade de seu tempo através da imprensa, que tinha um grande potencial de disseminação, atingindo desde o público analfabeto que escutava a leitura das revistas em voz alta nas ruas da cidade até o público de outros estados longínquos, que recebiam impressões da capital [...].

"Esse esforço por comunicação e clareza”, escreve Corrêa, procurava levar uma "fala brasileira" para um público amplo, fazendo uma ponte entre a linguagem falada e a da sociedade dos doutores. (BARRETO, 2017, p. 17) 
Em A cidade das letras, Ángel Rama analisa longamente como o domínio da linguagem se impõe como instrumento de poder exercido por aqueles que ocupam a cidade letrada e os numerosos que são alijados dela e que não dominam a "norma cortesã procedente da península", fazendo uso da "popular e cotidiana" (RAMA, 1985, p. 56). "A cidade letrada", escreve o crítico, "quer ser fixa e atemporal" e se opõe à "cidade real, que só existe na história e se adequa às transformações da sociedade" (RAMA, 1985, p. 65, grifo do autor).

O quadro que Rama descreve ao falar da cidade modernizada, (1985, pp. 76101), aquela dos anos 1870, não difere muito do mundo que Lima Barreto orbita. Os doutores, aqueles da cidade letrada, andam nos calcanhares do poder e nele se revezam, galgando cargos políticos, a fim de manterem seus privilégios. Basta lembrar que Sevcenko chama o Rio de Janeiro da Primeira República de "capital do arrivismo" (2003, pp. 36-57) e André Nunes de Azevedo descreve o "grande homem da República" como aquele que "percebia as oportunidades e não as deixava escapar" (2017, p. 89).

Lima Barreto, conquanto criticasse ácida e constantemente os habitantes da cidade das letras, queria tomá-la de assalto. Como, graças ao expediente dos pseudônimos, essas revistas não fossem a melhor vitrine para autores iniciantes que precisavam encontrar um lugar, Lima decidiu fundar seu próprio veículo. Floreal nasceria ainda em 1907 (BARRETO, 2016, pp. 19-21).

Fundada com amigos, como Antônio Noronha Santos e Domingos Ribeiro Filho, que frequentavam com ele os cafés Jeremias e Papagaio, a Floreal durou apenas quatro números. Com pobres recursos materiais, poucas ilustrações, era difícil que a publicação amadora conquistasse a atenção do leitor, que tinha à disposição dezenas de periódicos, de tipos variados (SCHWARCZ, 2017, p. 195).

Foi na Floreal, porém, que Lima Barreto pôde mostrar pela primeira vez ao público sua ficção, publicando capítulos daquele que viria a ser seu primeiro romance, Recordações do escrivão Isaías Caminha, no qual se narram as desventuras do protagonista, como o autor, mulato em busca de um título de doutor e de visibilidade social, que tem suas ambições tolhidas pelo preconceito racial e acaba engolfado pela vida na cidade, trabalhando num jornal diário. 
Era um romance à clef que pouco disfarçava as carnes dos personagens reais, os quais rapidamente se identificaram nas caricaturas - como Edmundo Bittencourt, proprietário do Correio da Manhã, e João do Rio, cronista dos mais populares da cidade. Com isso Isaías Caminha definiria - ou enterraria - o destino de Lima na grande imprensa.

Para Beatriz Resende, é esse o fator que sela a opção de Lima Barreto pelas revistas, para as quais colaboraria como cronista, "garantindo sua independência frente ao poder exercido pelos poderosos da imprensa e tornando-o um especial intérprete da cidade, imune à frequente cooptação que ocorria com os intelectuais”. Mesmo nas épocas em que teve textos em publicações mais elegantes e com mais recursos, como Careta e Revista Souza Cruz, continuou colaborando com as pequenas, “de oposição ao poder constituído” (RESENDE, 2004, p. 11, vol. 1).

Lilia Schwarcz lista mais de quinze publicações com as quais Lima Barreto colaborou no período que vai de 1910 a 1915. "Os locais, os periódicos e as orientações eram distintos, mas Lima era sempre ele mesmo: desfazia dos políticos, dos costumes, das instituições” (SCHWARCZ, 2017, pp. 292-3).

Entre as revistas para as quais Lima por essa época escreveria estavam a Careta, uma das mais populares de seu tempo, e a A.B.C., com tons mais políticos, e às duas ofereceria suas colaborações mais constantes - escreveu para a primeira por dois períodos, primeiro ao longo de 1915 e depois de 1919 a 1922, ano de sua morte; para a segunda, produziu de 1917 até 1922. Mas colaborou também com jornais mais modestos e assinaria textos, a partir de 1913, em periódicos bem mais alternativos, ligados a entidades de classe, como sindicatos, que começariam a surgir em paralelo à organização do movimento operário no país, em resposta ao vazio de legislação que ordenasse a substituição do trabalho servil pela mão de obra assalariada.

No trecho do Diário íntimo destacado mais acima, aparecia o desprezo de Lima pela República, sentimento no qual entrelaçam-se o trauma pessoal, devido ao que a queda da Monarquia traria para sua família, e uma percepção mais ampla, disseminada em parte da sociedade, de que o regime era corrupto.

Com a República, sai de cena a centralizadora "figura do monarca como controlador da ética no trato da coisa pública", abrindo espaço para escândalos de 
improbidade, "que tomaram a imprensa e criaram uma sensação de que de agora por diante o que valorizava e mensurava as pessoas seria a aquisição financeira" (AZEVEDO, 2017, p. 245).

Lima não se furtaria a expor seu descontentamento com o regime, em repetidos escritos, como a crônica a seguir, que citamos integralmente, por condensar em um breve espaço vários dos temas que lhe seriam caros. O texto foi publicado no Correio da Noite, com o qual o escritor colaborou por dois anos, até começar a escrever para a Careta. O texto saiu a 3 de março de 1915, sob o título de "O momento" (BARRETO, 2004, p. 174, vol. 1).

Sempre fui contra a república. Tinha sete anos e vinha do colégio primário, do grande colégio de que me lembro sempre com ternura e cheio de saudades da minha boa professora, Dona Teresa Pimentel do Amaral, quando me disseram que se havia proclamado a república.

Não tinha naqueles tempos outras cogitações que não fossem a de glória, a da grande, imensa glória, feita por mim sem favor, nem misericórdia, e vi que a tal de república, que tinha sido feita, espalhava pelas ruas soldados embalados, de carabinas em funeral.

Nunca mais a estimei, nunca mais a quis.

Sem ser monarquista, não amo a república.

[O escritor] João Ribeiro disse-me, certa vez, que a república era a cultura parda; pois sou como o Senhor João Ribeiro; nunca houve anos no Brasil em que os pardos, os malditos do seu Haeckel, fossem mais postos à margem.

O nosso regímen atual é da mais brutal plutocracia, da mais intensa adulação aos elementos estranhos, aos capitalismos internacionais, aos agentes de negócios, aos charlatães tintos com um uma sabedoria de pacotilha.

Não há entre os ricos, entre os poderosos, nenhuma generosidade; não há piedade, não há vontade, por parte deles, desejo de atenuar a sua felicidade, que é sempre uma injustiça, com a proteção aos outros, com o arrimo aos necessitados, com o fervor religioso de fazer bem.

Têm medo de ser generosos, têm medo de dar uma esmola, têm medo de ser bons.

Se a dissolução de costumes que todos anunciam como existente, há, antes dela houve a dissolução do sentimento, do imarcescível sentimento de solidariedade entre os homens.

$\mathrm{Eu}$, há mais de vinte anos, vi a implantação do regímen. Vi-a com desgosto e creio que tive razão. 
Como dissemos acima, a crônica oferece uma entrada para debater diversas convicções e temas que obcecavam o escritor e que contextualizamos a seguir.

Dona Teresa, a professora do primário, como o escritor registraria em "Maio", havia sido também a portadora da notícia de que chegara a Abolição.

A mestra teve um papel afetivo importante na infância do escritor. Ela daria ao menino Afonso - a essa altura já órfão de mãe e morando no Rio com a irmã Evangelina, enquanto o pai se instalava na remota Ilha do Governador - um de seus primeiros, se não o primeiro livro, volume este que o escritor conservou por toda a vida, As grandes invenções antigas e modernas nas ciências, indústrias e artes: obra para uso da mocidade, de Louis Figuier (SCHWARCZ, 2017, p.61). O exemplar, que hoje se encontra entre seus manuscritos na Biblioteca Nacional, vinha com uma carinhosa e emocionada dedicatória (BARBOSA, 2017, p. 59):

\footnotetext{
Afonso, guarda esse livro como uma lembrança de quem se orgulha de ter desenvolvido um pouco tua grande inteligência, da qual muito espera nossa cara Pátria; lendo-o, procurarás imitar as virtudes e a força de vontade dos grandes vultos, que aí se apresentam etc.
}

A inteligência promissora do menino, como já vimos, não bastaria para que o jovem funcionário fosse reconhecido pela "cara Pátria”. Ao escrever "O momento", ele contava já 33 anos e amargurava-se com o serviço público, que esperava logo deixar, sem ter feito grandes progressos na carreira. Era, por outro lado, já conhecido - além das crônicas e do muito comentado e pouco querido Recordações de Isaías Caminha, a essa altura ele havia publicado em folhetim, entre 1911 e 1912, Triste fim de Policarpo Quaresma e Numa e a ninfa, obras nas quais aliás critica a República ${ }^{18}$ - e talvez o fato de continuar a trabalhar em uma unidade do governo tão ligada às origens militares do regime, a Secretaria da Guerra, explique o fato de Lima, no texto, declararse explicitamente não monarquista na crônica.

${ }^{18}$ Abordaremos os livros em mais detalhe no capítulo 2. 
A questão racial está claramente enunciada no escrito. Pardo como era, Lima enquadra-se entre os marginalizados da República, os "malditos do seu Haeckel”. O positivista Ernst Heinrich Philipp August Haeckel (1834-1919), foi um dos nomes responsáveis pela vulgarização do evolucionismo de Darwin nas tais teorias do coletivo - que, como vimos, determinavam, pelo viés da ciência, o lugar cabido a negros e mestiços no quadro social. O escritor, ciente da necessidade de conhecer seus inimigos, guardava em sua Limana - apelido que deu à sua biblioteca, que ele mesmo inventariou 19 -, volumes de autores que defendiam o determinismo racial (SCHWARCZ, 2017, p. 320).

O preconceito sofrido pelas pessoas não brancas era tema do autor já em 1904; nesse ano, faz em seu Diário íntimo (BARRETO, 1961) os primeiros esboços de obras literárias. Estão ali as primeiras anotações, sem data, para Clara dos Anjos (pp. 54-61), por exemplo, além de notas intituladas “Opiniões do Gomensoro”, arrazoado composto de máximas que respondem justamente às crenças deterministas que pregavam a inferioridade dos negros (pp. 61-2) - dizeres como "A capacidade mental dos negros é discutida a priori e a dos brancos, a posteriori”.

A questão das origens de Lima Barreto - o termo era o que ele próprio empregava para se referir aos seus antepassados escravizados - norteia a experiência do escritor. O preconceito de raça, que delimita o lugar social do negro, a tristeza de não ser branco (BARRETO, 1961, p. 130) está nos escritos íntimos, em crônicas e em contos; está no primeiro romance que publica, Recordações de Isaías Caminha (1909) e no último, o póstumo Clara dos Anjos (editado em folhetim pela revista Mundo Literário entre 1923 e 1924).

Em "O momento", Lima faz menção aos "elementos estranhos" e aos “capitalistas internacionais”. São expressões que nos levam ao nacionalismo, uma questão que surge de forma ambivalente na obra do escritor.

Se, por um lado, Lima Barreto promoveria uma busca do que é próprio e brasileiro - na língua, nos usos, nos costumes - , por outro se defenderia do que

19 O inventário das obras que guardava em sua última casa em Todos os Santos consta como apêndice da biografia escrita por Francisco de Assis Barbosa e é quase só o que sobreviveu da biblioteca. Conforme conta Lilia Schwarcz (2017, p. 509), após a morte do escritor, os livros foram doados pela família ao arquiteto José Mariano Filho, em agradecimento por este ter custeado o sepultamento de Lima. Desapareceram em sua maior parte, salvo uns poucos que sobraram, em péssimo estado. 
Nicolau Sevcenko chama de "nacionalismo intelectual", expresso por exemplo na "preocupação militarista defensiva de Olavo Bilac", exacerbada pela Primeira Guerra Mundial, como escreve o historiador (SEVCENKO, 2003, p. 105).

Lima escreveria tanto contra "o nosso 'ianquismo" quanto contra "o nosso caboclismo" (BARRETO, 2004, p.480, vol. 1; p. 32, vol. 2). Sua defesa do nacional passa, em grande medida, pelo ataque ao cosmopolitismo e ao bovarismo, que funcionam como polos opostos da questão para o escritor.

Segundo Sevcenko, Lima julgava que a monarquia havia atingido um alto grau de interpenetração étnica, que se perdera com a burguesia republicana, em seu afã cosmopolitista. O escritor via na mestiçagem brasileira um motivo para a plena adaptação ao meio, à "natureza tropical e virente do Brasil". A insistência em querer parecer uma nação branca aos olhos dos estrangeiros, que só viam o Brasil como exótico e pitoresco, fazia dos nacionais eles também estrangeiros, tanto quanto europeus ou americanos (SEVCENKO, 2003, pp. 209-11).

Lilia Schwarcz define a atitude bovarista como "uma maneira complexa de lidar com a própria circunstância e projetar a vida e a sorte para outro local", "uma atitude de evasão do imaginário, que implicava conceber-se sempre como outro, diferente do que se é”. Como também nos lembra a historiadora, o conceito de bovarismo foi cunhado pelo filósofo Jules de Gaultier, jornalista do Mercure de France, uma das revistas que Lima lia com frequência. A teoria de Gaultier, de acordo com Schwarcz, "girava em torno do poder da ilusão e da capacidade humana de se conceber a partir do que não se é" - assim como Emma Bovary, a protagonista do romance de Flaubert (1857), da qual pode-se dizer que "tinha dificuldade em 'habitar' sua própria realidade e assim criava sempre outra para viver" (SCHWARCZ, 2017, p. 155, grifo da autora).

Segundo Sevcenko, se, por um lado, o bovarismo teria o condão de orientar o homem no sentido de objetivos mais altos, por outro, poderia se tornar devaneio completo, na ausência de espírito crítico. "O ufanismo bovarista" caricaturizado na figura do major Policarpo Quaresma "era outra forma de se alienar do país, só que parecendo que se estava fazendo exatamente o contrário" - uma espécie de "cosmopolitismo às avessas" (SEVCENKO, 2003, p. 213). 
O próprio Lima reconheceria a atitude em si próprio e se digladiaria com essa certeza, dando indícios de seu bovarismo em seu diário, ao anotar suas impressões acerca da obra de Gaultier (BARRETO, 1961, p. 93-4). Schwarcz lista alguns aspectos que denotam o bovarismo do autor (2017, p. 155):

na época da Politécnica desdenhava dos alunos e da profissão de engenheiro; vivendo da profissão de amanuense, fazia pouco do funcionalismo público; morador do subúrbio, sentia-se desconfortável quando era confundido com seus colegas de trem.

Como anota a historiadora, o bovarismo, segundo Gaultier, não era apenas uma atitude individual, podendo ser verificada em grupos e mesmo em nações.

Beatriz Resende aponta outro aspecto da questão nacionalista em Lima Barreto. Segundo a crítica literária, os anos de início da Primeira Guerra Mundial, período de colaboração com o Correio da Noite, levam Lima a refletir sobre os conceitos de pátria e nacionalismo, de uma forma que, por ser inovadora, não foi compreendida por muito tempo (RESENDE, 2004, p. 12, vol. 1).

\begin{abstract}
Os textos que escreve a propósito do conflito mundial revelam a aspiração por um conceito mais amplo de nação, entendida como conjunto de cidadãos, de homens unidos por um sentimento maior de solidariedade. É essa compreensão que o leva a questionar a noção de pátria, recusando o ufanismo e o nacionalismo excludente.
\end{abstract}

Esse sentimento maior de solidariedade que Resende coloca como uma inovação longamente incompreendida foi visto por Antonio Arnoni Prado como uma espécie de diluição do pensamento político de pendor anarquista do escritor.

Prado aponta para a contradição que existe entre a convicção política de Lima Barreto e o que ele de fato alcança, no nível da expressão. Para o crítico, o "vigor revolucionário do projeto anarquista" de Lima - iniciado com a colaboração para $A$ Voz do Trabalhador, em 1913 - se vê diluído num "solidarismo piedoso" e "de tendência individualista, inspirado no ideal e na caridade", um "sentimento reformista de fundo moral”. Esse sentimento impediria que Lima se aprofundasse politicamente, 
mesmo se ele se mostrou um receptor e difusor precoce das teses maximalistas ${ }^{20}$ que informaram a Revolução de Outubro de 1917 (PRADO, 1976, pp. 85-6), "a revolução proletária na base de suas aspirações totais, e não 'minimalista”' (SCHWARCZ, 2017, p. 363).

Segundo Prado, convivem em Lima a consciência e o despreparo para assumir essa consciência intelectualmente, o que se deve ao fato de que o escritor trava uma "luta implacável para obter o reconhecimento do sistema que o exclui" (PRADO, 1976, p. 14). O crítico diz que o anarquismo de Lima é importante no contraste com um quadro em que vigia um "espírito de neutralidade intelectual”, "imposta pelo dinheiro e pelos títulos, impedindo que a agitação de qualquer ideia repercutisse na massa" (PRADO, 1976, p. 82). Mais do que isso, vigiam também noções que buscavam domar a massa - como a de que a propriedade privada seria o grande estímulo para o esforço individual (BOTELHO, 2002).

De um lado, o escritor se revolta contra o espírito burguês e a exploração do homem e enuncia "as contradições que ameaçam o sistema" - como os fundamentos da propriedade, a questão agrária, a marginalização urbana de trabalhadores. De outro, alimenta uma crença ingênua na “conversão moral do opressor", da velha ordem, a mesma que o rejeita (PRADO, 1976, p. 14; pp. 84-7).

Nos conturbados anos do conflito mundial, Lima Barreto travava também uma guerra íntima. O álcool, que ele começara a consumir desde a doença do pai, passara, por sua vez, a consumi-lo. Desde 1906, vinha tirando licenças para tratamento de saúde até que, em 1914, sofreu sua primeira internação devida ao alcoolismo.

Francisco de Assis Barbosa recolhe depoimentos de quem o conheceu naquela altura da vida; descuidado no vestir, maltrapilho mesmo; caindo pelas sarjetas; desaparecendo das tertúlias nos cafés para beber sozinho, andando enormes distâncias, parando para beber, "até não mais poder, tonto de álcool e morto de cansaço". O desregramento culminou numa crise delirante que fez com que os irmãos decidissem mandá-lo uns dias para a casa de um tio em Guaratiba, de onde saiu num

${ }^{20} \mathrm{O}$ artigo "No ajuste de contas..." é considerado o "manifesto maximalista" de Lima. Publicado pela A.B.C. em 11 de maio de 1918, o texto defende o fim dos latifúndios, o confisco de bens de ordens religiosas e o divórcio, entre outras ideias - "confesso que foi a revolução russa que me inspirou tudo isso", escreve ele, antes de terminar, lembrando Kant e Goethe, e concluir com um "Ave Rússia!" (BARRETO, 2004, pp. 336-43). 
camburão, convocado por seu irmão Carlindo, que era policial, diretamente para o hospício - episódio que o escritor, ultrajado, jamais perdoaria e que ficcionalizou em “Como o 'homem' chegou”, publicado, ao lado de outros contos, em apêndice à edição em livro de Triste fim de Policarpo Quaresma, no ano seguinte (BARBOSA, 2017, 21927).

O ano de 1914 é um dos mais parcos do Diário íntimo - talvez porque Lima estivesse vivendo dessa forma tão desregrada. Em 13 de julho, duvidou de sua sanidade: "Noto que estou mudando de gênio. Hoje tive um pavor burro. Estarei indo para a loucura?” - curioso notar que coloca a perda de razão como um destino, um lugar ao qual chegar, influenciado talvez pelas teorias deterministas que não aceitava, mas quiçá temesse serem verdadeiras. O pai já chegara lá. A internação, ocorrida cerca de um mês depois, merece apenas uma anotação sem data: "Estive no hospício de 188-14 a 13-10-14" (BARRETO, 1961, p. 172). Seria, porém, reelaborada em vários escritos, em especial no romance que deixou inacabado, $O$ cemitério dos vivos, planejado durante sua segunda internação no hospício, que durou de 25 de dezembro de 1919 a 2 de fevereiro de 1920.

O alcoolismo que se agravava, desgastando a saúde do escritor, o levara ao afastamento físico, à marginalização extrema, a do hospício; da "casa do louco"21 para a casa dos loucos - à qual, em O cemitério dos vivos, ele associaria à Casa dos mortos de Dostoiévski (BARRETO, 2017, p. 147). A doença lhe causaria ainda grave deterioração física, tendo que ser internado em hospital também, no ano de 1916. Entre uma e outra interrupção, contudo, trabalhava ferozmente. Passou a colaborar para mais revistas, editou seu Policarpo Quaresma e, no que Lilia Schwarcz vê como um esforço para ser reconhecido profissionalmente, vinculou-se a associações de classe (2017, p. 289).

No clima conturbado da guerra, fundam-se também as primeiras entidades de defesa dos interesses profissionais de escritores. Até ali, os intelectuais, forçados pelo limitado âmbito do mercado editorial - sendo a população brasileira majoritariamente analfabeta - a se dedicarem ao jornalismo, ao funcionalismo ou à política, contavam

${ }^{21}$ Da casa da r. Boa Vista, hoje Elisa de Albuquerque, que ficara conhecida como a "casa do louco", a família se mudaria em 1913, para a r. Major Mascarenhas, 42, também em Todos os Santos. Este ainda não seria o endereço final de Lima Barreto, porém. Em 1918, mudariam-se para o n. 26 da mesma rua, onde o autor morreria (BARRETO, 1961, PP. 169-70). 
somente com a Academia Brasileira de Letras, um reduto muito restrito, disputado como uma espécie de aposentadoria (SEVCENKO, 2003, p. 128).

Surgem, portanto, agremiações como a Sociedade dos Autores ou a Sociedade Brasileira dos Homens de Letras, fundada em 1914 e da qual Lima Barreto fez parte. Ele já havia participado das festas em homenagem a Olavo Bilac, feito Príncipe dos Poetas Brasileiros em concurso da Fon-Fon, e havia, anos antes, em 1911, se empenhado para criar uma Academia Livre de Letras ou Academia dos Novos (SCHWARCZ, 2017, p. 289).

Lima Barreto, escreve Lilia Schwarcz "integrava-se e se isolava, tudo ao mesmo tempo" (2017, p. 292). A biógrafa nota que, a essa altura, o escritor angariava popularidade, não só no Rio. Em 1912, recorda a historiadora, foi personagem de um diálogo fictício criado por um jornalista da revista Rio-Nú. Mais tarde, em 1915, já autor de Triste fim de Policarpo Quaresma, foi entrevistado numa enquete da revista $O$ Pirralho, a respeito do estado das letras cariocas; o interesse da publicação paulista mostra que sua literatura chamava atenção fora das fronteiras locais (SCHWARCZ, 2017, p. 294; pp. 375-6).

Talvez impelido por acontecimentos como esses, candidata-se duas vezes à Academia Brasileira de Letras, em 1917 e em 191922, apenas para fracassar, em uma ilustração clara daquela "luta implacável para obter o reconhecimento do sistema que o exclui” de que falava Antonio Arnoni Prado (1976, p. 14).

Nesses anos agitados do fim da primeira década do século $\mathrm{XX}$, com a visibilidade dada por tantas colaborações, Lima passaria a ser muito procurado por outros escritores, que lhe mandariam exemplares seus, esperando um comentário público do autor de Policarpo Quaresma. A partir de 1918, intensifica-se na produção do escritor para a imprensa esse tipo de resenha, a tal grau que, em 1920, ele escreve na A.B.C. temer que sua colaboração com a revista se limite à crônica literária - como lembra Beatriz Resende na introdução ao volume no qual reuniu as "impressões de leitura” (2017a, p. 37). A leitura dessa coletânea deixa ver que, apesar do temor, Lima

22 Tentaria uma terceira vez, em 1921, na vaga de Paulo Barreto, o João do Rio, retirando a candidatura "por motivos inteiramente particulares e íntimos" (apud BARBOSA, 2017, p. 275). 
quase sempre extrapola os limites da crítica literária para fazer crítica social, expondo suas convicções, passando da resenha ao ensaio.

Eis que, então, o escritor tinha conquistado um lugar próprio nessa sociedade dos homens letrados. Um lugar bastante particular - excêntrico, poderíamos dizer novamente. Se, por um lado, não conseguira se estabelecer pelos meios oficiais da cidade letrada, sendo rechaçado por exemplo pela $\mathrm{ABL}$, obtivera uma reputação no meio, com sua estratégia de exposição.

"Havia de ser ele, um pobre-diabo, sem dinheiro e sem posição, quem incentivaria escritores novos", resume, empaticamente, Francisco de Assis Barbosa (2017, p. 314).

Lima sentia, porém, que vinha perdendo do álcool. Desde 1917, fora acometido por uma espécie de febre de arrumação; além de inventariar a Limana, começou a organizar todos seus escritos de jornal para publicações em livro (BARBOSA, 2017, 304-5).

Em 1918, resolveu que era chegada a hora de publicar Vida e morte de M. $J$. Gonzaga de Sá. Escrito em paralelo a Recordações do escrivão Isaías Caminha, o livro tinha ficado na gaveta por uma década. Para isso, recorreu a Monteiro Lobato. O escritor paulista passara a editar a Revista do Brasil e montara a editora que levava seu nome, lançando livros com cuidado gráfico inédito para a época. Enviados os exemplares, em novembro, recebeu como resposta, pouco depois, uma carta com a única promessa editorial decente que teria em sua vida. Depois de ter ele mesmo bancado a maior parte de seus livros, com muito custo, obteve do editor paulista um aceite sem que este nem mesmo lesse os originais - e, além disso, uma proposta financeira (SCHWARCZ, 2017, pp. 377-8).

Era enfim tratado como escritor profissional, como um nome reconhecido.

Não era o primeiro contato que tinham o paulista e o carioca - Lobato já o havia convidado, em setembro daquele ano, a colaborar com a Revista do Brasil, de forma lisonjeira. Convite que foi aceito; Lima enviou um conto, "O moleque", que Lobato publicou. Começaria uma amizade epistolar. 
Gonzaga de Sá foi bem recebido pela crítica, mas não lhe trouxe fama; a situação pessoal e familiar não melhorava. Mesmo se tinha mais tempo - pois finalmente conseguira se aposentar em dezembro de 1918, após várias licenças médicas e pedidos anteriores para deixar o serviço - , revistas começam, por sugestão do próprio Lima, a "referver" crônicas publicadas anteriormente quando ele, debilitado, não conseguia atender os pedidos de textos, conforme recorda Beatriz Resende (2004, pp. 16-7, vol. 1). O ano de 1919 não acabou em boa nota. No Natal, viria a já mencionada segunda internação, relatada nas notas depois publicadas como Diário do hospício e $O$ cemitério dos vivos, peças literárias que se mesclam. No diário pessoal, as anotações escasseam - mas não a correspondência com os jovens escritores (SCHWARCZ, 2017, p. 432).

Francisco de Assis Barbosa recolhe o depoimento do escritor e crítico paulista Sérgio Milliet, que recorda a admiração que o autor de Triste fim de Policarpo Quaresma suscitava nos futuros modernistas de 1922. "O que mais nos espantava então era o estilo direto, a precisão descritiva da frase, a atitude antiliterária do escritor, a limpeza de sua prosa, objetivos que os modernistas também visavam”, diz Milliet ao biógrafo (BARBOSA, 2017, p. 316).

Essa admiração, aliás, desembocaria num episódio de contornos tristes. Os jovens paulistas, no ímpeto da realização da Semana de Arte Moderna, fundaram a revista Klaxon. Sérgio Buarque de Holanda foi encontrar Lima Barreto no Rio e levoulhe um exemplar. Incapaz de conter sua ironia ao comentar a publicação em texto para a Careta, não conseguiu reconhecer os pontos em comum que tinha com a nascente agenda modernista e provocou a ira do grupo. Lilia Schwarcz analisa em detalhe o contexto da má recepção de Klaxon por Lima, indagando-se sobre o que a poderia ter motivado. E, embora a biógrafa frise que "história de 'se' não existe”, é impossível não pensarmos um pouco sobre o que poderia ter acontecido à recepção da obra do escritor carioca caso ele tivesse se aproximado dos paulistas (SCHWARCZ, 2017, 447-8).

Afinal, o ideário pós-Semana de 22 teria tal impacto que os contemporâneos de Lima Barreto entrariam para a história da literatura pelo que não foram. A produção de nomes que tiveram, à época, mais leitores e prestígio do que o nosso autor - nomes como Coelho Neto e Benjamin Costallat, cujas obras tinham tiragens de 5.000 exemplares, maiores que a de um romance médio nos dias atuais - ficou conhecida 
sob a rubrica de "pré-modernistas" (RESENDE, 2016, pp. 16-7). Muito embora esse rótulo venha sendo questionado, entende-se quão limitador ele possa ter sido, por anos, para os estudos da literatura de então.

O episódio da Klaxon, no fim da vida de Lima, coroaria o estado de decadência do escritor, que só fazia se acentuar. Antes dele, ainda em 1921, o médico Ranulfo Prata, ele também escritor dos que com ele trocavam cartas, decide colocá-lo sob seus cuidados na cidade de Mirassol, no interior paulista, onde clinicava. Diante da piora acentuada que seu pai vinha apresentando, cansado e frustrado, Lima aceitou o convite, apostando numa melhora trazida pela mudança de ares. Comprou até roupa nova para a longa viagem de trem paga por Ranulfo, com parada em São Paulo, onde esperava por fim ver Lobato em pessoa, tudo animadamente relatado em crônicas publicadas entre abril e maio na revista Careta (SCHWARCZ, 2017, p. 433-6).

Na pacata e encantadora Mirassol, onde todo mundo se conhecia, Lima seguiu as prescrições de abstinência e descanso feitas pelo amigo médico. Ia até melhorando. Mas, na pacata e encantadora Mirassol, era novidade ter um escritor conhecido. Os amigos de Ranulfo Prata, empolgados, concertaram para Lima uma conferência em São José do Rio Preto. Seria a primeira da vida do escritor, que, tenso, não conseguia mais repousar. Na data e hora marcadas para a viagem, ninguém sabia onde estava. Até que Ranulfo Prata o encontrou, bêbado e jogado numa sarjeta (BARBOSA, 2017, pp. 322-3).

De volta ao Rio, sua vida passou a ficar cada vez mais restrita à Vila Quilombo - como, "para enfezar Copacabana", batizara aquela que seria sua última casa (BARRETO, 2004, p. 499, vol. 2).

As contribuições para a imprensa se multiplicam não só porque, aposentado, dispunha de mais tempo mas também porque, pela mesma condição, faltava-lhe dinheiro - a aposentadoria mal dava para o aluguel da casa, e não tirar da pena glória, mas tão somente dinheiro lhe causava tremenda frustração, como registra Francisco de Assis Barbosa (2017, p. 332).

A reclusão forçada pelas circunstâncias não significa, entretanto, que ignorasse os acontecimentos da vida nacional, comentando em artigos, por exemplo, a política e as reformas da cidade, que seguiam, já sob a batuta (ou picareta) do prefeito Carlos 
Sampaio. É notável, contudo, que nos últimos dois anos de vida, os quais coincidem com seu recolhimento em Todos os Santos, o cotidiano suburbano se fez mais presente nos escritos para a imprensa, o que é facilmente comprovável pelos índices de seus volumes de crônicas reunidas. Não por acaso, nessa época se dedica a finalizar o tão longamente acalentado Clara dos Anjos, que conclui entre dezembro de 1921 e janeiro de 1922, mas que acabaria não vendo publicado, nem em sua primeira versão, como folhetim.

Pouco deixaria seu triste refúgio; no Centenário da Independência - para cujas comemorações o Rio se engalanara, com o desfigurado bairro da Misericórdia transformado em "antessala do Paraíso", recebendo pavilhões de todos os estados da federação e outros tantos internacionais (JOÃO; LENZ; BEZERRA, 2016, p. 77) -, daria um passeio com ares de despedida. "Era o seu adeus ao Rio de Janeiro, talvez pressentido, já que vivia a pensar constantemente na morte.” (BARBOSA, 2017, p.333)

A morte pilhou-o no quarto, onde repousava na tarde de $1^{\circ}$ de novembro de 1922, Dia de Todos os Santos. Lima tinha andado meio doente, mas naquele dia chuvoso era João Henriques quem mais preocupava Evangelina, que ainda vivia na Vila Quilombo a cuidar do pai e do irmão mais velho. Pensava que Afonso só precisaria de mais uns dias de cama e, instada por ele mesmo, foi cuidar do pai. À tardinha serviu ao irmão chá e torradas, acomodando a bandeja na cama. "Uma hora depois, retornando ao quarto, encontraria o irmão morto. Continuava sentado, abraçado a um volume da Revue des Deux Mondes." (BARBOSA, 2017, pp. 338-9)

Já não caminhando sozinho até a estação com seus sapatos sujos, mas acompanhado por uma "foule anônima", faria sua última viagem para fora do subúrbio onde vivera por vinte anos. Naquele Dia de Finados, o caixão levando o corpo do escritor foi conduzido, pelos trilhos da Central do Brasil, até a cidade - onde, no bairro de Botafogo que em tantos escritos deplorou, foi enterrado, a seu pedido, no cemitério São João Batista. (BARBOSA, 2017, pp. 339-40). 


\subsection{Lima, o militante}

A conferência que Lima Barreto nunca proferiu passou para a história como seu testamento literário, sua profissão de fé.

O conceito de solidariedade a promover a união entre os homens, que Beatriz Resende identifica como elemento central da peculiar noção de nacionalismo de Lima Barreto, é fundamental para compreender "O destino da literatura" - esse é o nome do texto que, nunca pronunciado, foi publicado na Revista Sousa Cruz, na edição de outubro e novembro de 1921, no qual faz a defesa da "literatura militante".

A ideia de uma literatura que se interessasse pela sociedade, que nascesse mesmo dos temas sociais e que tivesse por objetivo final unir diferentes grupos remonta a bem mais cedo no pensamento de Lima Barreto. Como recorda Lilia Schwarcz, havia sido expressa por ele já no primeiro número de Floreal, em 1907 lembrando, ainda, que um ponto em comum entre os fundadores da revista era que nutriam simpatia pelo ideário anarquista (2017, pp. 199-200).

Como vimos anteriormente, a partir de 1918 os textos sobre temas literários, muitas vezes resenhas de livros de seus contemporâneos, tornam-se mais frequentes. Naquele ano, a 7 de setembro, ele publica na A.B.C. um artigo intitulado "Literatura militante”.

O texto toma por mote outro artigo, de Carlos Malheiro Dias, que saíra em $O$ País e que tratava de Anatole France, autor de predileção de Lima Barreto. O escritor questiona a ideia de seu par de que a fama do autor francês seria uma prova do bom gosto das elites nacionais, posto que não se justificaria a venda de tantos exemplares se eles fossem adquiridos somente por “aprendizes, militantes e honorários” (apud BARRETO, 2017a, pp. 128-9).

Lima capta o "desprezo" de Malheiro Dias. "Como eu sempre falei em literatura militante, se bem me julgando aprendiz, mas não honorário, pois já tenho publicado livros, tomei o pião na unha”, escreve. “A começar por Anatole France, a grande literatura tem sido militante". Argumenta que as obras de France, se não divulgam um credo social, têm escopo sociológico - militam, diz. Em seguida, explica que vem do 
poeta e filósofo Jean-Marie Guyau o preceito de que o destino da obra de arte é "revelar umas almas às outras", "restabelecer entre elas uma ligação necessária ao mútuo entendimento dos homens" (BARRETO, 2017a, p. 129).

Eis a solidariedade, mais uma vez, encarnada no discurso de Lima como aspiração maior da sociedade.

"A velha terra lusa tem um grande passado. Nós não temos nenhum; só temos futuro. E é dele que a nossa literatura deve tratar, da maneira literária”, segue, pregando a necessidade de união, de compreensão, "para bem suportarmos o fardo da vida e dos nossos destinos". Rechaçando, como soía, a literatura que falava da aristocracia de Laranjeiras ou Botafogo, diz que cumpre à arte mostrar "que um negro, um índio, um português ou um italiano se podem entender e se podem amar, no interesse comum de todos nós” (BARRETO, 2017a, pp. 129-30).

Lima Barreto cita ainda Eça de Queirós - a quem atribui o uso do termo "literatura militante" -, Hippolyte Taine e Ferdinand Brunetière, autores franceses que, como Eça, estavam entre as leituras diletas do escritor e que seriam retomados por ele sempre que surgisse a questão da literatura militante.

Aludido, mas não nomeado, é Coelho Neto, um "doido que andou na moda e cujo nome não cito", o qual "proclamou a sua grande admiração pelos leões, tigres e jaguares" - em referência ao Fabulário, uma das obras daquele que seria uma espécie de nêmese de Lima. Mas, segue nosso autor, “à proporção que essas feras desaparecem, os homens, os bois e os carneiros conquistam o mundo com a sua solidariedade entre eles" (BARRETO, 2017a, pp. 130-1). Lima toma o partido, de maneira muito clara, dos oprimidos, os que não têm o poder - das garras ou do dinheiro - deixando Coelho Neto do lado de lá.

A questão de Lima Barreto com Coelho Neto não deve ser compreendida no âmbito da ojeriza pessoal. Antes, seria o caso de entender que, para Lima, a obra do escritor e político maranhense, fundador da cadeira n. 2 da Academia Brasileira de Letras, que fez carreira como deputado federal por seu estado, era o antiexemplo acabado daquilo que o autor de Clara dos Anjos defendia como função da literatura, função eminentemente social. 
"Desde o primeiro livro publicado por Lima Barreto, estabeleceu-se um conflito definitivo entre sua produção literária e os detentores do poder cultural na cidade letrada, capital da República Velha”, escreve Beatriz Resende. Ao romper com os "mandarins da literatura", segue ela, expõe-se a não ser contemplado pelo "discurso legitimador da crítica oficial”, mas essa marginalidade lhe garantiria a independência, num momento em que a "cooptação dos intelectuais pelo poder é mais do que frequente, é praticamente a única situação existente numa cidade onde o saber autêntico não se constitui, por si só, em valor ou forma de ascensão social”. (RESENDE, 2016, pp. 17-8).

Para Resende, como também já expressara Sérgio Milliet, conforme vimos acima, Lima Barreto antecipa a "instauração do novo que vai se dar na escrita modernista", contra o "coelhonetismo". Na visão de Lima Barreto e de seu grupo de amigos, Coelho Neto representava a retórica ornamental dos "brindes de sobremesa"; representava mesmo o antagonismo entre os bairros "aristocráticos" e os subúrbios (RESENDE, 2016, pp. 18-9).

Exemplo de suas críticas ao literato está em outro artigo de 1918, publicado a 18 de janeiro em A Lanterna - periódico anarquista homônimo daquele dos alunos da Escola Politécnica no qual Lima pela primeira vez ensaiara o futuro ofício. Em "Literatura e política", comentava o fato de que Coelho Neto não havia sido escolhido para tentar se reeleger deputado nas eleições seguintes - desde 1909 ele havia representado o Maranhão.

Lima Barreto inicia como quem se escusa. "A coisa tem levantado tanta celeuma nos arraiais literários, que me julgo obrigado a tratar do escandaloso acontecimento, pedindo que não vejam nestas considerações a mínima hostilidade ao conhecido escritor." E, como se a frisar a distância que o separa do "conhecido escritor", acrescenta: "Por mais que não queiram, eu também sou literato e o que toca a coisas de letras não me é indiferente” (BARRETO, 2017a, p. 135, grifo nosso).

Para Lima, a debacle de Coelho Neto é muito facilmente explicável para quem "descobre as suas tendências literárias e espirituais". Segue-se um retrato de Coelho Neto como um alienado nas duas arenas, que aliás Lima Barreto não distingue, não perdoando no político o romancista - "grande romancista" (BARRETO, 2017 a, pp. 136-7), aliás, mas que 
ficou sendo unicamente um plástico, um contemplativo, magnetizado pelo Flaubert da Mme. Bovary, com as suas chinesices de estilo, querendo como os Goncourt pintar com a palavra escrita, e sempre fascinado por uma Grécia que talvez não seja a que existiu mas, mesmo que fosse, só nos deve interessar arqueologicamente.

O mundo é hoje mais rico e mais complexo...

[...] Se ele estivesse ao par dos males do seu tempo, com o talento que tem, e o prestígio do seu nome, poderia ter apresentado muita medida útil e original, embora os seus projetos morressem nas pastas das comissões. Mas nada fez; manteve-se mudo, só dando um ar de sua graça para justificar votos de congratulações a Portugal, por isto ou por aquilo, empregando nos discursos vocábulos senis ou caducos. O deputado ficou sendo o romancista que só se preocupou com o estilo, com o vocabulário, com a paisagem, mas que não fez do seu instrumento artístico um veículo de difusão das grandes ideias do tempo, em quem não repercutiram as ânsias de infinita justiça dos seus dias [...]

Trecho exemplar de tantos aspectos do pensamento de Lima Barreto que já trouxemos: o rebuscamento da linguagem, o formalismo passadista, o cosmopolitismo de quem louva o estrangeiro; não falta nem mesmo a Madame Bovary, com tudo que já viemos que simbolizava, no âmbito do pensamento de Lima. Como não faltaria, logo em seguida, a menção literal à literatura militante, "cheia de preocupações políticas, morais e sociais" (BARRETO, 2017a, p. 137).

O que desaguaria na conferência que o escritor nunca pronunciou em Mirassol era uma teoria estética e ética que de há muito lhe povoava as ideias e que sintetizaria as demais inclinações ideológicas e questões que conformaram seu pensamento e que vimos sintetizando e analisando até aqui.

Lima começa o texto da conferência desculpando-se pela beleza que ele próprio não tem, diferente do seu "camarada O.M." - o poeta Olegário Mariano, cujos atributos físicos, escreve, atraíam para suas palestras uma enorme quantidade de senhoras (BARRETO, 2017a, pp. 265-6). Passa daí à sua falta de jeito com plateias, rememorando que, na adolescência, se comparava a personagens geniais que, tal como ele, não sabiam falar em público - Isaac Newton e o geômetra Gomes de Sousa, estavam entre os "muitos mais grandes homens" que tinha a seu lado, o que, diz com autoironia, o fazia supor que pudesse ser ele também um gênio.

Beleza, sociabilidade, inteligência. As faculdades sobre as quais, a partir de si próprio, constrói sua glosa inicial são as mesmas que nortearão sua análise da função 
da literatura. "Em que pode a Literatura, ou a Arte, contribuir para a felicidade de um povo, de uma nação, da humanidade, enfim?” (BARRETO, 2017a, p. 269). Para responder a questão sobre a função - ou o destino - da literatura, Lima acudirá aos seus heróis que, se explica, cita de cabeça, por não ter com ele seus livros.

De Tolstói, em O que é a Arte?, busca teorias estéticas, sumarizadas pelo autor russo. “O que é a Beleza?”, pergunta (BARRETO, 2017a, p. 271). A resposta o leva a procurar outros autores, como Taine, que diz que a beleza é a manifestação da essência de uma ideia. "É a substância da obra, não são as suas aparências" - uma defesa do conteúdo vigindo sobre a forma (BARRETO, 2017a, p. 272).

As teses de Brunetière, ele procura abordar a partir de uma análise de Crime $e$ castigo, de Dostoiévski, romance, como se sabe, sobre o assassinato de uma velha usurária por um jovem estudante em dificuldades financeiras, trama na qual "não há nada do que comumente entre os escritores mais ou menos helenizantes chamam belo”. Mas, sendo assim, inquire, “onde está a beleza dessa estranha obra?”. E responde: ela está na capacidade de transformar uma ideia, um argumento - no caso, o de que nenhum assassinato é justificável - , em sentimento (BARRETO, 2017a, p. 274).

Passa ao combate do "ideal grego", argumentando que o que se sonha sobre a velha Grécia "varia muito"; e que, por ser fugidia, não pode essa Grécia imaginada servir de aspiração, posto que isso impede a realização de um ideal próprio, “aquele que está na nossa consciência, vivo no fundo de nós mesmos, para procurar a beleza em uma carcaça cujos ossos já se fazem pó” (BARRETO, 2017a, p. 277).

Não cabe tampouco à arte ser apenas agradável (BARRETO, 2017a, p. 278).

\footnotetext{
Ver o fim, o destino de qualquer arte no prazer que ela nos proporciona é imitar os homens de uma moralidade primitiva, como os selvagens, que não veem na alimentação outro alcance que não seja o da satisfação agradável que lhes proporciona a ingestão de alimentos.
}

Chega, por fim, a Guyau, "o genial filósofo, esteta, moralista e poeta, morto prematuramente aos 33 anos”. Dele, tomará uma divisa: “Ama tudo para tudo compreender; tudo compreender para tudo perdoar" (BARRETO, 2017a, p. 279). 
Mais do que qualquer outra atividade espiritual da nossa espécie, a Arte, especialmente a Literatura, a que me dediquei e com que me casei; mais do que ela nenhum outro qualquer meio de comunicação entre os homens, em virtude mesmo do seu poder de contágio, teve, tem e terá um grande destino na nossa triste Humanidade.

"O destino da literatura", diz Lima, deixava afinal de ser unicamente a beleza ideia essa que sintetiza o "anticoelhonetismo" do escritor. É preciso que prevaleça a inteligência, principal força humana, para promover a sociabilidade, que depende da linguagem para se efetivar (BARRETO, 2017a, p. 279).

Os homens só dominam os outros animais e conseguem em seu proveito ir captando as forças naturais porque são inteligentes. A sua verdadeira força é a inteligência; e o progresso e o desenvolvimento desta decorrem do fato de sermos nós animais sociáveis, dispondo de um meio quase perfeito de comunicação, que é a linguagem, com a qual nos é permitido somar e multiplicar a força de pensamento do indivíduo, da família, das nações e das raças, e, até, mesmo, das gerações passadas, graças à escrita e à tradição oral que guardam as cogitações e conquistas mentais delas e as ligam às subsequentes.

Portanto, meus senhores, quanto mais perfeito for esse poder de associação; quanto mais compreendermos os outros que nos parecem, à primeira vista, mais diferentes, mais intensa será a ligação entre os homens, e mais nos amaremos mutuamente, ganhando com isso a nossa inteligência, não só a coletiva como a individual.

A conclusão leva ao laço solidário entre os homens, sempre ele. "Fazendo-nos assim tudo compreender" - para tudo perdoar, diríamos com Guyau - "entrando no segredo das vidas e das cousas, a Literatura reforça o nosso natural sentimento de solidariedade com os nossos semelhantes [...]” (BARRETO, 2017a, p. 280).

Eis a "missão quase divina" da literatura, e pelo cumprimento desse ideal fraterno deve se bater o escritor, não importando o risco do ridículo. "A literatura é um sacerdócio, dizia Carlyle" (BARRETO, 2017a, p. 281). 


\subsection{O lugar da ficção}

Falamos, ao princípio deste capítulo, da presença da vida na obra de Lima Barreto. Antonio Candido, em "Os olhos, a barca e o espelho", um dos ensaios que dedicou ao estudo do autor carioca, analisa as implicações da prevalência biográfica na produção de sua literatura. Entre as características de sua produção, frisa o peso que o escritor dava à sinceridade, no sentido de transmitir de forma direta as ideias do autor, bem como a importância que dedicava aos problemas humanos e sociais. São todos tópicos que vimos ao longo deste capítulo.

Para o crítico, contudo, de certa forma essa "concepção empenhada" contribuiu para atrapalhar a "realização plena do ficcionista", que acaba "sacudido entre altos e baixos, frequentemente incapaz de transformar o sentimento e a ideia em algo propriamente criativo". Segundo Candido, os escritos pessoais do escritor mostram "de que maneira o interesse de seus romances pode estar em material às vezes pouco elaborado ficcionalmente, mas cabível enquanto testemunho, reflexão, impressão de cunho individual ou intuito social" (2000, p. 40).

Talvez Lima Barreto não discordasse cabalmente de Candido; afinal, em seu credo literário, expressou a defesa do conteúdo sobre a forma.

Ainda nesse mesmo ensaio, o crítico frisa a identificação plena que tecia Lima Barreto entre vida e fazer literário. De certa maneira glosando o que diz o escritor em "O destino da literatura", Candido nota que era tão acentuada essa ligação que o "lado subjetivo" da literatura "não se destaca do outro, que é seu efeito e o seu papel fundamental: estabelecer comunicação entre os homens”.

O autor, escreve o crítico, "canalizou a própria vida para a literatura, que a absorveu e tomou o seu lugar; e esta doação de si mesmo atrapalhou-o paradoxalmente a ver a literatura como arte".

Há também que considerar o que vimos na análise de "O destino da literatura" - o fato de que Lima queria se opor ao que era entendido como arte em seu tempo, as noções de belo vigentes que ele considerava arcaizantes. Por isso, escreve Candido, 
"rejeitava de cambulhada com o bem-feito e o bem-acabado, como quem nega a face da iniquidade na literatura e por isso quer mostrar o real desmascarado” (p. 41).

É diante desses aspectos que, na opinião do crítico, os escritos pessoais e artigos de Lima Barreto servem melhor à concepção de literatura que tinha o autor, que buscava declaradamente "a representação direta da realidade", sendo os "recursos expressivos" como "intermediários incômodos” (CANDIDO, 2000, p.41).

Candido assinala ainda que essa característica salta na forma como Lima Barreto lia seus circunstantes, em suas “impressões de leitura”, tão comuns a partir de 1918. Nelas, diz o crítico, Lima trata romances como se fossem documentos, e não ficção, e os aprecia ou deixa de apreciar segundo esse parâmetro - "mostrando desinteresse pelos aspectos formais, sobretudo os inovadores". "É como se a sua consciência artística decorresse do desejo polêmico de não ter consciência artística propriamente dita." (CANDIDO, 2000, p. 41)

Nos próximos capítulos, nos serviremos da ficção de Lima Barreto, em especial de alguns de seus romances. Ainda que seja temerário incorrer no que Candido reprova acima no Lima resenhista, procuraremos entender as obras ficcionais como documento não apenas pelo que nos dizem - mas também pela maneira como o dizem.

Que em nosso auxílio venha o que diz Luiz Costa Lima: “a função última da ficção é apresentar a verdadeira face do poder” (2008, p. 176).

O que significa dizer: a ficção tem a vocação crítica de mostrar aquilo que estava nos seduzindo. Isso, porém, não a torna verdade; mas nos diz que ela é o meio humano para que, através de um discurso que se autoapresenta como não verdade, apreenda-se a verdade. 


\section{Capítulo 2: a nova vida no centro do poder}

No final de 1903, enquanto Lima Barreto começava, por força das contingências, uma nova fase, morando no subúrbio e trabalhando como amanuense na Secretaria da Guerra, que ficava na praça da República, no centro da cidade, também o Rio de Janeiro iniciava uma nova etapa.

A região central da cidade se transformava sob a gestão do prefeito Pereira Passos, que havia sido nomeado nos últimos dias de 1902.

As primeiras modificações seriam nos usos e costumes. Adeus vendedores de leite direto da vaca; a venda ambulante de bilhetes de loteria e de miúdos de rês também fora vetada; carnes verdes, ou seja, aquelas comercializadas logo após o abate dos animais, só no novo matadouro-modelo, com projeto encomendado naquele ano, bem como seriam feitos planos para novos jardins e um aquário; nada de quiosques, que vendiam pães, sardinha, vinho e outros víveres, sem licença. As fachadas dos imóveis que davam para a rua deveriam estar pintadas ou caiadas, consertadas e limpas. As habitações sofreriam inspeção sanitária, com lavagem dos depósitos de água. Mendigos e esmoleres deveriam ser recolhidos das ruas, sendo os incapacitados mandados para o Asilo São Francisco de Assis, e os demais, às autoridades competentes. Tudo isso só até março de 1903 (BRENNA, 1985, pp. 23-38) - e decidido por decretos, pois, para que o prefeito pudesse agir com celeridade, o Conselho Municipal fora suspenso por seis meses a partir de sua posse.

Em 13 de abril daquele ano, foram anunciados os melhoramentos projetados pelo prefeito Pereira Passos, a serem promovidos pela municipalidade - o governo federal tinha um plano separado para a cidade, no qual se incluía a abertura da avenida Central 23 , que se tornaria o aspecto mais simbólico das reformas. No documento assinado por Alfredo Américo de Souza Rangel, chefe da Comissão da Carta Cadastral do Distrito Federal, está resumido principalmente o plano viário, com definição das novas avenidas, inclusive a que viria a ser a Beira-Mar, explicitando quais seriam as demolições a serem feitas e explicando que o trajeto e a largura das futuras vias levava em conta a melhor economia possível considerando o elevado número de

${ }_{23}^{23}$ Hoje avenida Rio Branco. O nome foi mudado após a morte do barão de Rio Branco, em 1912. 
desapropriações a fazer. Assim concluía o relatório divulgado: (BRENNA, 1984, pp. 437).

\begin{abstract}
O total dos orçamentos atinge a 79.000 contos. Releva considerar, porém, que as desapropriações estão calculadas na elevada base da Lei vigente e que, uma vez efetuadas, ficará a Municipalidade possuidora de terrenos com cerca de oito mil metros de frente nas novas avenidas, terrenos cuja renda produzirá por certo elevada quantia, pois que terão inquestionavelmente maior valor do que atualmente têm.

As novas avenidas têm uma extensão total de cerca de treze quilômetros e exigem a demolição de 1.040 prédios.
\end{abstract}

As primeiras demolições tiveram início já no dia seguinte, na rua Senhor dos Passos, para o prolongamento da rua do Sacramento. (BRENNA, 1985, p. 49)

Nos jornais, opina-se sobre o que era prioritário; melhor o embelezamento ou as questões sanitárias? Cobra-se o início das obras para requalificar o porto, parte principal do conjunto de reformas planejado pelo governo federal. Em maio, o Ministério da Fazenda é autorizado a contrair junto aos banqueiros londrinos N.M. Rotschild \& Sons um empréstimo de 8,5 milhões de libras esterlinas para as obras do porto e outras, complementares - o que rapidamente causa espanto (BRENNA, 1985, pp. 51-5). A soma contratada em Londres equivalia a quase metade do Orçamento da União, que apostava de fato muito alto no novo porto para alavancar as importações a maior parte da arrecadação fiscal sobre os artigos que entravam ficava para os cofres federais. A avenida Central, originalmente, foi pensada com a finalidade principal de escoar as mercadorias que chegavam, que até sua abertura dependiam de caminhos tortuosos conformados por ruas estreitas para chegarem do isolado porto até as lojas do centro da cidade (AZEVEDO, 2017, p. 143-152).

Enquanto isso, Pereira Passos continuava usando de seus plenos poderes - cuja prorrogação era aventada na Câmara - para estabelecer, novas medidas de ordem, como a proibição, em maio, de escarrar em bondes e vias públicas (BRENNA, 1985, pp. 53-4).

A $1^{0}$ de junho de 1903, "O País", que se dizia "a folha de maior tiragem e de maior circulação da América do Sul" dedica sua capa a uma reportagem intitulada "Os 
novos cais"24. Curiosamente, o texto, ilustrado com um mapa e desenhos dos futuros armazéns, ostenta um portentoso "nariz de cera" - nome que, no jargão jornalístico atual, se dá a um início que posterga o assunto que é efetivamente a notícia. A reportagem começa não falando do que se fará no porto, mas elogiando as obras viárias tocadas sob "a égide calma e tenaz do atual benemérito prefeito" para em seguida constatar que também “a vida, os hábitos, os costumes” vão se modificar. No parágrafo seguinte, diz, "certos tipos populares e característicos da terra”, que hão de ser alterados em sua "significação social" uns até desaparecendo, caso dos "sujos e pitorescos esmoleres das almas" (MORALES DE LOS RIOS, A., "O País”, 1.jun.1903, p. 1).

Destaca-se o fato de que as responsabilidades municipais e federais pelas reformas começassem já a se misturar na imprensa e, certamente, também entre seus leitores. Só ao final da primeira página é que, em meio às detalhadas descrições das obras, se mencionam “a iniciativa e inteligente tenacidade do Sr. Dr. Muller”, qual seja, Lauro Muller, ex-governador de Santa Catarina e ministro da Viação e Obras Públicas do governo Rodrigues Alves (MORALES DE LOS RIOS, A., O País, 1.jun.1903, pp. 12).

O Rio de Janeiro passava por uma enorme operação - e pouco importava o nome do cirurgião.

Seria possível continuar por páginas e páginas a fio descrevendo intervenções iniciadas e medidas tomadas apenas nesse primeiro ano de novo governo. E elas ainda seriam pequenas perto do que estava por vir nos anos seguintes. Segundo escreve Francisco de Assis Barbosa, o Rio, em 1903, "ainda estava longe de ser uma grande cidade". Nem era possível que tão radical transformação se operasse da noite para o dia [...]”. Citando um cronista da época que não nomeia, diz que os primeiros negócios que apostaram na pujança da cidade renovada não prosperaram; o povo, diz o cronista no livro de Barbosa, "continuou a mover-se sem pressa, e só com o tempo foi adaptando hábitos ancestrais ao novo ambiente" (BARBOSA, 2017, p. 136).

\footnotetext{
${ }^{24}$ Segundo a ortografia de então, o jornal se chamava "O Paiz" e o título do texto era "Os novos caes". Optamos por atualizar todos os textos e títulos de periódicos pela grafia vigente.
} 
Repassar ano a ano o que ocorreu no Rio de Janeiro em reformas seria ocioso; publicações já sistematizaram essas informações, a começar pelo essencial trabalho organizado por Giovanna Rosso Del Brenna. Por ora, o que foi enunciado até aqui basta para compreendermos que o centro do Rio de Janeiro que Lima Barreto passa a frequentar como morador do subúrbio iria paulatinamente, à força de novos costumes decretados, se tornar muito diferente daquele que, até pouco antes, ele havia habitado como morador de uma pensão na rua das Marrecas.

O ano mais simbólico das reformas seria 1904, que Del Brenna nomeia, em seu livro, "o ano das demolições" - o famoso "bota-abaixo" que terminaria para sempre pespegado ao nome de Pereira Passos.

Aquele foi também o ano da Revolta da Vacina, sublevação popular que tomou as ruas da cidade, em boa parte insuflada pela oposição florianista, em reação ao decreto - cujo texto foi esboçado pelo próprio Oswaldo Cruz, diretor da Saúde Pública -, que determinava imunização compulsória contra a varíola. A doença assolava o Rio, ao lado da febre amarela, que dera à cidade o apelido de "túmulo do estrangeiro". Quanto à varíola, naquele ano, ela mataria mais de 4.000 pessoas. Já os mortos pela revolta, não seria possível contabilizar (SEVCENKO, 2013).

Lima Barreto não ficaria insensível aos acontecimentos. Em seu diário - na realidade, anotações esparsas em cadernetas e folhas soltas, inclusive em papéis da Secretaria da Guerra, reunidas cuidadosamente como Diário íntimo por Francisco de Assis Barbosa - anota suas impressões do novo Rio e dos acontecimentos, em meio a esboços variados de obras e resenhas de leituras.

Sobre a Revolta da Vacina, ele faz uma anotação, sem data, na qual dá uma visão bem peculiar dos fatos - bastante diferente, por exemplo, da percepção expressa por Olavo Bilac, que em uma famosa crônica para a revista Kosmos diria que as arruaças da revolta eram prova de que não tínhamos um povo (BILAC, O. Kosmos, nov.1904, s.n.). Vejamos o que escreve o jovem amanuense Afonso (BARRETO, 1961, pp. 47-8). Ele enxerga, justamente, um povo:

Durante as mazorcas de novembro de 1904, eu vi a seguinte e curiosa cousa: um grupo de agentes fazia parar os cidadãos e os revistava. 
O governo diz que os oposicionistas à vacina, com armas na mão, são vagabundos, gatunos, assassinos, entretanto ele se esquece que o fundo dos seus batalhões, dos seus secretas e inspetores, que mantêm a opinião dele, é da mesma gente.

Essa mazorca teve grandes vantagens $1^{\mathrm{a}}$ ) demonstrar que o Rio de Janeiro pode ter opinião e defendê-la com armas na mão; $2^{\mathrm{a}}$ ) diminuir um pouco o fetichismo da farda; $3^{\text {a }}$ ) desmoralizar a Escola Militar.

Pela vez primeira, eu vi entre nós não se ter medo de homem fardado. O povo, como os astecas ao tempo de Cortés, se convenceu de que eles também eram mortais.

O Argolo [ministro da Guerra, superior de Lima], parece, queria nesse movimento resgatar a pouca bravura que teve em 9 de fevereiro.

As notas sobre a revolta continuam, sempre em tom meio retumbante; mais adiante profetiza: "Dos militares mais ou menos envolvidos nas mazorcas, nenhum sofrerá pena; dos civis, alguns se suicidarão na prisão”. Critica seu superior, o marechal Francisco de Paula Argolo, dizendo que não possui “majestade e dignidade" por ter, em meio aos acontecimentos, ao lado do general Piragibe, dado "ordens de simples inspetores em altas vozes e das sacadas de duas Secretarias de Estado". Preocupado com o tom das críticas, diz ter mantido o caderno "prudentemente escondido trinta dias". "Não fui ameaçado, mas temo sobremodo os governos do Brasil" (BARRETO, 1961, pP. 48-9).

O ano de 1905, é mais pródigo em anotações - a 31 de janeiro revela que havia se decidido a escrever todos os dias, promessa que não cumprirá (BARRETO, 1961, p. 96). Muito do que registra são impressões sobre a cidade, feitas em seus deslocamentos, que não eram poucos. Talvez, como aventa Antonio Arnoni Prado (1976, p. 56), pela infelicidade em casa, que Lima aponta no diário, talvez simplesmente por ser um rapaz de 24 anos, saía muito. Encontrava-se com amigos em casa e na rua, com os quais falava de literatura e de fundar uma revista; ia ao teatro; passeava até o Leme para ver o mar; anotava, em tom lírico, descrições da paisagem, céu e montanhas, que vê da janela do trem (BARRETO, 1961, pp. 71-101).

Depois de fevereiro, há apenas várias notas sem data até julho. Portanto não sabemos o que ele pensa da colaboração que faria, entre abril e junho de 1905, para o 
Correio da Manhã. A 17 de janeiro, há observações pouco lisonjeiras sobre o proprietário do jornal, Edmundo Bittencourt. Entre seus apontamentos na data, Lima cola um texto de Bittencourt, não reproduzido na edição do Diário íntimo, dizendo que não é "dos mais primorosos". Em seguida descreve a ocasião em que se conheceram, apresentados por um conhecido comum na rua da Quitanda, no centro, e como mais tarde, passando pelo jornalista, este o ignorou (BARRETO, 1961, pp. 87-8). Dois dias depois, conta que Bittencourt fora preso por causa daquele mesmo artigo que ele tinha guardado e passa a invectivas contra o chefe da polícia. O nome de Bittencourt não reaparece nas anotações, assim como não há qualquer referência ao convite para escrever no Correio da Manhã, que deve ter partido de um dos amigos de Lima que trabalhavam no jornal, Pausílipo da Fonseca e Bastos Tigre (BARBOSA, 2017, p. 141).

A série "O subterrâneo do morro do Castelo" sairia de 28 de abril a 3 de junho de 1905, consistindo em 26 textos publicados sem assinatura ${ }^{25}$, motivados pela lenda de que existiria um tesouro de jesuítas enterrado nas entranhas do morro.

O Correio da Manhã, um dos principais da grande imprensa carioca de então e, no dizer de Francisco de Assis Barbosa o "mais desabusado" (2017, p. 141), já havia dedicado textos esparsos à remoção da população do morro, devida a escavações para a realização das obras da Avenida Central. Reportagem de 5 de janeiro de 1905 visita a casa de cômodos do antigo seminário de São José, no morro do Castelo, onde uma multidão de desesperados, brasileiros e estrangeiros, prestes a ser desalojada, se perguntava como acharia morada que pudesse pagar com o conteúdo de seus bolsos esfarrapados (BRENNA, 1985, 294-9). Ainda naquele ano, a carestia que expulsava a classe média e o operariado do centro foi tema da série "Vida e miséria", publicada pelo Jornal do Brasil (BRENNA, 1985, pp. 358-65).

Considerado então como um obstáculo à saúde pública, porque impediria a boa circulação do ar e a dispersão de miasmas que, acreditava-se, eram causadores de enfermidades, o morro do Castelo já tinha sua destruição aventada desde 1853, quando um decreto autorizou que, assim como o morro de Santo Antônio, fosse arrasado

\footnotetext{
${ }^{25} \mathrm{Em}$ A vida de Lima Barreto, Francisco de Assis Barbosa - que encontrou entre os papéis do escritor manuscritos do folhetim sobre D. Garça, do qual falaremos adiante - afirma que as reportagens são "inquestionavelmente de sua autoria" (BARBOSA, 2017, p. 142). Contudo a autoria foi atribuída de fato a Lima quando da publicação da série de reportagens, até então anônima, em forma de livro. Isto se deu apenas em 1997, pela editora Dantes, com organização, introdução, e notas de Beatriz Resende, quem lembrou durante a banca a importância de deixar aqui este registro.
} 
(CHIAVARI, 1985, p.587). Um dos locais de fundação da cidade, o morro do Castelo só viria abaixo de fato em 1921, sob a gestão do prefeito Carlos Sampaio ${ }^{26}$.

A partir das publicações de maio, no texto jornalístico de Lima Barreto se introduz uma narrativa fantasiosa. Entra em cena um tal sr. Coelho, que teria informações sobre as riquezas nos subterrâneos graças ao fato de que, numa sessão espírita conduzida por ele, o engenheiro Paulo de Frontin, construtor da Avenida, teria incorporado o marquês de Pombal - expulsor dos jesuítas do Brasil em 1759, quando o tal tesouro teria sido escondido nas galerias escavadas no morro.

Mais adiante, Lima introduz, em meio a informações sobre o que acontecia durante as escavações, um romance acerca de uma condessa italiana, Alda, por alcunha D. Garça, com o comandante dos invasores franceses que cercavam a cidade, Duclerc. A trama é apresentada pelo narrador como sendo a transcrição de documentos encontrados nas galerias.

Com a história de D. Garça, Lima Barreto ensaia uma incursão num gênero então muito comum, o do romance-folhetim, nascido na França com uma fórmula coalhada de heróis, mosqueteiros, vingadores, mulheres fatais, sofredoras, histórias rocambolescas em que há crianças trocadas, mistérios, tesouros e que tinham como principal característica, além da fantasia, a de serem contadas aos pedaços. Um dos romances que contribuíram para o estabelecimento do gênero, Os mistérios de Paris, de Eugéne Sue, trata das aventuras de um príncipe pelos subterrâneos da capital francesa, onde habitam seus desvalidos; foi um retumbante sucesso. Traduzido mundialmente, circulou no Rio, publicado pelo Jornal do Comércio, entre 1844 e 1845 (MEYER, 2005).

Enquanto Lima Barreto, em 1905, ao ter a oportunidade de escrever sobre as modificações pelas quais passava cidade, ensaiava anonimamente sua verve literária numa trama fantasiosa - ainda que aproveitando para fazer troça de nomes do cenário político -, escritores que já assinavam seus nomes nos jornais e revistas teciam loas às reformas.

${ }^{26} \mathrm{O}$ morro de Santo Antônio, também um encrave habitado por populações pobres, viria abaixo nos anos 1950 . 
Olavo Bilac, ainda em junho de 1903, dizia temer que a Avenida, com a qual já tanto se sonhava, não ficasse pronta a contento, ou que, uma vez pronta, não fomentasse uma melhora na arquitetura local, que considerava lamentável (BRENNA, 1985, pp.66-7); no ano seguinte, na sua "Crônica", seção de abertura da Kosmos, tranquilizado pelo início das demolições, escreveria com alegria sobre o "hino jubiloso" das "picaretas regeneradoras" que cobria o "gemido soturno e lamentoso do Passado, do Atraso, do Opróbrio" (BILAC, O. “Kosmos”, mar.1904).

Sem ter onde se expressar publicamente - pois ainda não fundara sua Floreal -, Lima anotava no diário o que via no centro já depois do bota-abaixo, em 1905 (BARRETO, 1961, pp. 91-2).

\begin{abstract}
Saí e tomei um bonde e fui à Prainha. A rua está outra, não a conheci bem. Se os prédios fossem mais altos, eu me acreditaria em outra cidade. Estive na esquina dela com a avenida, a famosa avenida das indenizações, subi-a a pé, tomei pelo que resta de beco da rua Larga de São Joaquim, prolongada e alargada até o largo de Santa Rita. A rua quebra um pouco do primitivo alinhamento, mas mesmo assim ficará bela. Entretanto, como vêm já de boa administração essas modificações, acredito que o Rio, o meu tolerante Rio, bom e relaxado, belo e sujo, esquisito e harmônico, o meu Rio vai perder, se não lhe vier em troca um grande surto industrial e comercial; com ruas largas e sem ele, será uma aldeia pretensiosa de galante e distinta, como é o tal de São Paulo.
\end{abstract}

Lima Barreto já olhava com melancólica desconfiança para a urbe que ia se conformando, ponderando sobre o risco de que o belo se tornasse vazio, cenográfico termo que aliás mais tarde usaria para descrever o aspecto da cidade, como nos lembra Sevcenko (1998, p. 545). Ainda naquele mesmo 1905, Lima nos dá outra breve mostra de como via as transformações: "Deixando a botica, fui à rua do Ouvidor; como estava bonita, semiagitada! Era como um boulevard de Paris visto em fotografia" (BARRETO, 1961, p. 96). Sem ser indiferente à beleza, apontava-lhe o caráter artificial, de representação - uma imagem, e não a coisa real.

A percepção crítica de Lima Barreto quanto a essa índole cenográfica das mudanças, sem lastro na realidade social, se tornaria mais aguda com o tempo. Tendo já seu espaço na imprensa, passaria a se contrapor à visão expressa por seus 
contemporâneos "binoculares" ${ }^{27}$ acerca das modificações. Quanto mais sua vida se fixasse no subúrbio, mais se daria conta do abandono daquela região, em nome do desenvolvimento do centro e dos novos arrabaldes ao sul, e mais as críticas se fariam vivas e presentes em sua escrita, como veremos mais adiante.

\subsection{O ideário por trás das reformas}

Não é à toa que Lima Barreto, no trecho que destacamos acima, compara a Ouvidor - espinha dorsal da vida social e do chic do Rio até a construção da avenida Central - a um bulevar parisiense.

Depois da gigantesca operação a que foi submetida pelo barão de Haussmann, entre 1852 e 1870, ganhando as feições que conhecemos, Paris havia se tornado o exemplo acabado de metrópole moderna, exportando da Europa, em baús transatlânticos, o gosto, as modas e as normas do convívio social - a cultura em seu mais amplo sentido. Era assim como uma espécie de capital do mundo.

Aqui no grande sul, Buenos Aires se adiantaria, fazendo sua reforma urbana no final do século XIX e provocando uma rivalidade que ainda hoje nos é familiar. A capital argentina parecia mais civilizada; passara na frente do Rio no caminho para tornar-se uma Paris sul-americana.

A disputa era tão franca que, a 31 de dezembro de 1902, mal fora empossado Pereira Passos, o Jornal do Comércio registrava que o correspondente do jornal $E l$ Diario, de Buenos Aires, teria noticiado em seu jornal os planos do novo prefeito para o Rio. A notícia dizia ainda que Pereira Passos esperava contar com a boa vontade dos cariocas, embora as limitações financeiras não lhe permitissem fazer ali uma nova Buenos Aires, imitando o que pela capital argentina havia feito Alvear. O prefeito do Rio teve de começar o ano de 1903 negando ao Jornal do Comércio, no dia seguinte,

${ }^{27} \mathrm{O}$ adjetivo alude à seção "Binóculo", comandada por Alberto Figueiredo Pimentel de 1907 a 1914 na Gazeta de Notícias. Figueiredo Pimentel, que importou para o Rio hábitos como as batalhas de flores e o chá das cinco, é autor de uma frase que se tornou famosa para resumir a impressão geral acerca das reformas: "O Rio civiliza-se". Curiosamente, o colunista social morava no mesmo subúrbio de Todos os Santos onde vivia Lima Barreto. (CASTRO, 2019, p. 48) 
que tivesse compartilhado qualquer programa com o representante do diário argentino (BRENNA, 1985, pp. 21-2).

Curioso jogo de espelhos, que quase fazia supor que o objetivo das reformas fosse fazer do Rio de Janeiro uma Paris não de segunda, mas de terceira mão.

Em Miradas sobre Buenos Aires, Adrián Gorelik localiza a inspiração francesa da reforma de Alvear não na renovação urbana promovida por Haussmann, mas na “cultura engenheiresca politécnica hegemônica na França desde Napoleão e que também alimentou Haussmann em um processo de 'longa incubação" e "cuja chave reside na palavra regularização"; segundo Gorelik, essa cultura politécnica imagina uma cidade que se renova "sobre si mesma para dar conta das novas necessidades impostas pelo capitalismo" (GORELIK, 2004, p.81) ${ }^{28}$.

Para sustentar seu argumento, analisa o exemplo da avenida de Mayo, "obra que valeu a Alvear seus máximos galardões haussmanianos”. Para Gorelik, enquanto na capital francesa um bulevar é uma "via de circulação econômica para unir os pontos nevrálgicos de Paris atravessando a intrincada trama medieval”, falta à avenida de Mayo "o componente cenográfico barroco que certamente tinham os bulevares haussmanianos”. Isso porque a avenida portenha não foi prevista para ter dois arremates - o palácio do Congresso, que está em uma de suas extremidades, havia originalmente sido pensado para a avenida Córdoba, e só depois de começada a avenida de Mayo foi que se deu a mudança (2004, p. 82).

O raciocínio de Gorelik quanto ao componente barroco se refere à renovação de Roma durante o pontificado de Sisto V (1585-90). Conforme explicam Andrea Buchidid Loewen e Ricardo Marques de Azevedo (2006, p. 31), a reforma urbanística pensada pelo papa

é também de natureza religiosa e celebrativa, pois consiste em ligar, por meio
de vias retilíneas, as sete principais basílicas visitadas pelos peregrinos, além
de outros pontos estratégicos de Roma, reduzindo assim, idealmente, a
distância física entre os gloriosos e antigos monumentos que espelham a
prístina estrutura da cidade imperial através de uma conexão também visual. O
aspecto original do programa do papa, ideado pelo arquiteto Domenico
Fontana, apóia-se na identificação da importância da percepção óptica, direta,
da meta: encimados pela cruz, obeliscos simbolizam o triunfo da fé cristã sobre

${ }^{28}$ A tradução de todos os textos de Gorelik citados é nossa. 
o paganismo e são instrumentos compositivos relevantes, pois permitem a apreensão imediata dos vários focos perspécticos dos principais monumentos que agora se inscrevem numa cidade que então já conta em cem os milhares de residentes.

"Quando os monarcas europeus consolidam seu poder absolutista e lhes convém que suas capitais reflitam e reverberem a majestade e a glória, é na Roma restituída que está o paradigma para suas capitais" (LOEWEN; AZEVEDO, p. 31) e é também esse o modelo - em que se criam eixos que não só servem de comunicação mas também ressaltam monumentos em suas pontas - que, no Segundo Império estará por trás da reforma de Haussmann.

Quer dizer, segue Gorelik (2004, p. 82), que

em lugar de dispor o bulevar para realçar pontos monumentais da cidade existente [...], os pontos monumentais se constróem em Buenos Aires para arrematar um bulevar que, a priori, tinha de estar no eixo de simetria da cidade histórica simplesmente porque era o eixo de simetria e porque, como apontava criticamente Sarmiento, nessa tradição engenheiresca não havia outro modo de representar a cidade sem que fosse por meio de seu desenvolvimento concêntrico.

Esse preâmbulo parece derivar para muito longe do nosso objeto de estudo e, no entanto, nos leva a refletir sobre as motivações ideológicas que informaram as reformas às quais o Rio de Janeiro foi submetido no início do século XX.

Se Paris era entendida como o grande modelo de cidade a imitar, isso não se deve somente ao fato de que a intelectualidade de países como a Argentina ou o Brasil tinha a oportunidade de conhecer ao vivo seus bulevares. Em boa medida, o imaginário acerca da capital francesa se estabelecera com base na produção literária exportada. Repassemos um pouco que tipo de ideias circulavam nas páginas dos romances de todo tipo.

As cidades, desde o século XIX, vinham se impondo como um tema da literatura; os romances procuravam dar conta do novo cotidiano dos centros urbanos pós-Revolução Industrial, como nos lembra Ana Claudia Veiga de Castro (2016), acrescentando ainda que "a própria cidade passava a ser uma personagem, deixando de ser apenas palco ou cenários dos acontecimentos". 
Nas metrópoles, "a multidão, o choc em meio à refrega do tráfego" eram o fator marcante e nelas as individualidades se dissolviam "na viscidez do fluxo humano", como descreve Ricardo Marques de Azevedo (2006, p. 12).

No período da Restauração da monarquia francesa, após a queda de Napoleão Bonaparte, em 1814, antes da grande reformulação de Paris, "a literatura, com interesse, enfoca seu tempo, fomentando um imaginário no qual circulam ideias feitas que confrontam a aventurosa e dissimulada Paris à província tacanha e hipócrita”. É a época da Comédia Humana de Balzac, tentativa de formar um panorama que dê conta dos diferentes universos, as diversas populações que nela convivem sem hierarquia. Nessa metrópole, "tudo tem preço e somente por ele coisas e gentes são estimadas: lá nada há que não se mercadeje, impudicamente" (AZEVEDO, 2006, pp. 21-2, grifos do autor).

A vida da metrópole é oposta, em romances, à da província. Nesta, diferentemente do que naquela, não existe a privacidade garantida pelo anonimato, sendo Madame Bovary, de Flaubert - no qual a entediada Emma sonha com o fausto da capital e com uma paixão -, o exemplo máximo dessa oposição. Stendhal não vê saída nem na cidade, nem na província; para ele "é a época que vai mal". Já o naturalismo de Zola, em Germinal, vai opor sem nuances "bondade e generosidade proletárias" à "perversão dos vícios burgueses". É ainda a época do "homem da multidão" de Edgar Allan Poe (AZEVEDO, pp. 24-5).

Por fim, Baudelaire traduziria a metrópole não só como tema, mas como forma, absorvendo a "experiência do choc". Contra a crença baseada em Rousseau, que vê "que instila a espontaneidade do estado de natureza", Baudelaire "afirma o artifício" (AZEVEDO, pp. 26-7, grifos do autor).

Também no Brasil, recorda ainda Castro (2016) no supracitado artigo, a virada do século XIX para o XX viu a literatura crescer como "fonte para compreender as transformações das capitais brasileiras, que passavam por processos intensos, e quase sempre contraditórios, de modernização, nesse período pós-abolição e republicano”.

As produções literárias da Belle Époque, segundo Maria Alice Rezende de Carvalho, se caracterizariam pelo "jogo entre tradição e invenção, entre inovação e passado", que alimentaria, entre outras formas, as narrativas sobre a modernização da 
cidade. Escrevendo sobre a rua do Ouvidor, em sua opinião o logradouro que mais simbolizou "a potência e os embaraços do moderno", Carvalho recua ao tempo do Império para recordar outro folhetim anônimo, publicado pelo Jornal do Comércio, em 1878, Memórias da rua do Ouvidor (CARVALHO, 2019, p. 25).

A obra, que era de autoria de Joaquim Manuel de Macedo - autor iniciador do romantismo, com A moreninha, em 1844 -, não se propunha a ser fidedigna quanto à "verdade dos fatos" e à observação da rua, como pregava a perspectiva realista já então vigente, mas sim "apreender sua alma, desvelar seu sentido". O escritor integrou a geração boêmia que fez a fama da rua do Ouvidor, com seus cafés, até que, escreve Carvalho, "uma nova imprensa, profissional e popular, a reivindicou, não só ela mas as ruas em geral, como objeto jornalístico". Segundo a autora, a literatura realista e a imprensa profissional deslocaram gradualmente os imperiais romantismo e boemia aos quais pertencia Macedo (CARVALHO, 2019, p. 25-6).

Nesse momento, ainda na leitura de Carvalho, "românticos e liberais anglófilos do Brasil, cultivados nos valores da tradição e adeptos de um reformismo fraco, serão deslocados por liberais francófilos e, com a proclamação da República, positivistas", projetando "outro horizonte valorativo e utópico" que se reconhecerá na reforma de Pereira Passos. (CARVALHO, 2019, p. 26).

Retraçando não as memórias, mas a história do logradouro, Carvalho explica de que modo a rua do Ouvidor funcionava como uma passagem entre duas cidades, posto que unia o Paço, sede do poder de metrópole portuguesa, e o Rossio, o espaço plebeu. Que ele tenha passado de ser um logradouro que denotava a forte heterogeneidade social do Rio a um local de encontro e integração, onde pessoas de diferentes estratos sociais criavam laços afetivos, é fruto da operação intelectual de Macedo, um romântico vivendo sob o Império (CARVALHO, 2019, pp. 30-2).

Ainda segundo as Memórias de Macedo, o logradouro, pobre como era, foi ignorado pela Corte portuguesa desembarcada em 1808 - e só em 1816, com a chegada da Missão Francesa, trazendo artistas e modistas fugidos dos destroços do derrotado império napoleônico, a rua foi notada. "Macedo sugere, portanto, que foi a Paris plebeia que, ao chegar ao Rio de Janeiro, converteu a Ouvidor num sítio reconhecível pelas elites e autoridades locais". Depois das modistas, vieram outros comércios, 
artistas, livrarias, "tudo o que se convencionou chamar de "progresso"” - era enfim a Ouvidor dos tempos vividos por Macedo (CARVALHO, 2019, pp. 32-3).

Mais do que isso, Macedo não arrisca, abstendo-se de tecer conjecturas acerca da Ouvidor dos anos 1870. O escritor encontrou na via em transformação na Belle Époque "o signo do declínio, quando a maioria de seus contemporâneos viu nela a expressão do progresso". O autor de A moreninha era um membro da elite intelectual do Império e, falando da rua do Ouvidor, falava também de si, num momento em que, segue Carvalho, não por acaso (CARVALHO, 2019, pp. 34-6),

\begin{abstract}
a engenharia no Brasil e suas instituições - a Escola Politécnica, o Clube de Engenharia, fundado em 1880 , e as publicações do setor - ocupam a cena política e cultural do Rio de Janeiro, tendo os seus valores e procedimentos assimilados como um novo método para observação e correção da sociedade.
\end{abstract}

É um éthos semelhante ao da "tradição engenheiresca" que Gorelik identifica em Buenos Aires. Foi essa a tradição que conformou os primeiros anos do urbanismo brasileiro, com profissionais como o fluminense Francisco Saturnino de Brito, considerado pai da engenharia sanitária no país, reformando cidades portuárias, como Vitória, ainda no fim do século XIX, e Recife, na primeira década do século XX. Aos arquitetos - estrangeiros como o italiano Pedro Campofiorito e o francês Emílio Tessain, que atuaram na renovação para que Niterói se tornasse capital do Estado, em 1903 - cabiam edifícios, jardins e similares (LEME, 1999, pp. 20-5).

A substituição do Brasil de bacharéis do Império pelo Brasil de engenheiros na República é uma das chaves para entender as reformas do Rio, segundo André Nunes de Azevedo (2017), que as lê a partir da evolução dos conceitos de civilização e progresso entre o Segundo Reinado e o advento republicano ${ }^{29}$.

Em suas últimas décadas, tempo das memórias de Joaquim Manuel de Macedo, o Império encontrava-se numa encruzilhada, percebendo que as estruturas fundamentais que o sustentavam, o Poder Moderador e a escravidão, eram empecilhos

\footnotetext{
${ }^{29}$ Salvo indicação contrária no texto, as ideias que retraçam a oposição entre civilização e progresso e seu quadro histórico, a partir deste ponto e até o final desta seção do capítulo, dependem do trabalho de André Nunes de Azevedo. Uma vez que as citações indiretas por vezes condensam ideias vindas de partes separadas do texto de Azevedo, serão localizadas explicitamente no texto apenas citações diretas de seu livro e as eventuais intervenções aportadas por outras fontes.
} 
à inserção do Brasil no mundo ocidental. O consenso político foi ruindo, e a ideia da República se sedimentando, a partir da queda do gabinete liberal de Zacarias Góes, com a ascensão do conservador Caxias, em 1868, e da Lei do Ventre Livre, em 1871, que afetou a sustentação dos cafeicultores paulistas à Coroa. Surgiria o Partido Liberal Radical e, depois, o Partido Republicano. Percebendo os abalos, o Império notou a necessidade de uma ação simbólica para buscar legitimar o poder imperial, recuperar sua imagem de “justo juiz”.

Para tanto, a Coroa iria defender uma visão reformista gradualista, pautada numa ideia de civilização, da qual a noção de progresso era subsidiária - progresso era sinônimo de avanço, de evolução no tempo, um caminho, e não um fim; mesmo nos léxicos, até 1890, o termo progresso não teria acepção de "progresso material", ideia que, no discurso do Império, era abarcada pelo termo "prosperidade”, também ela um caminho para a civilização. A busca por fomentar uma educação científica se voltaria para um modelo francês, humanista, mais afim à tradição de ensino jesuítica que dominara até então. Entre outras instituições modernizadas segundo esse modelo, a Escola Central se tornou, em 1874, Escola Politécnica. Tão presente era o caráter humanista que a estrutura do ensino da engenharia por volta essa época valorizava o latim acima do domínio matemático, e a escola ganhou de seu primeiro diretor já como Politécnica, o barão de Rio Branco, uma cadeira de humanidades - ele próprio ministrando as disciplinas de economia política e direito administrativo. Foi essa a Escola Politécnica que formou o engenheiro Francisco Pereira Passos.

A ideia de uma civilização com lastro no passado se confrontaria com a nova realidade econômica criada pela Segunda Revolução Industrial e pela crise econômica de 1873. A exportação de capitais por parte dos países industrializados da Europa dotou o setor de serviços da cidade de mais infraestrutura e equipamentos, como iluminação e bondes. Essa europeização pelos serviços fez surgir uma demanda por tecnologia e produtos também importados; um interesse pelo "moderno". A vida social e de entretenimento também se incrementou, com cafés, salões, teatros, cassino. Esse conjunto de fatores estimularia a aceitação da ideia de progresso técnico e material como um valor em si, autônomo.

O surgimento do Clube de Engenharia, em 1880, se dá num momento em que já era impossível ignorar que a cidade do Rio de Janeiro - ainda em grande medida 
colonial, com vias estreitas, coalhada de ambulantes, negros, mestiços e imigrantes descamisados e descalços, com um porto que não acomodava o fluxo de importação que recebia - não era o que estava destinada a ser. Já em 1875 houvera uma primeira tentativa de renovação da cidade, feita por uma comissão imperial que contava com Pereira Passos entre seus membros e que, no entanto, foi considerada insuficiente em termos sanitários, privilegiando a estética, e muito cara.

Apercebendo-se da oportunidade de atuarem como auxiliares do Estado e assumirem o comando das grandes obras de que o Rio flagrantemente carecia, os engenheiros, liderados pelo industrial Conrado Niemeyer, fundaram sua agremiação. Sua visão era de que eles seriam empreendedores, construtores do futuro, em oposição à engenharia do serviço público, com funcionários do Estado, como Pereira Passos. Na visão do órgão, o progresso passa a ser autônomo, um ideal em si - a civilização dependeria dele, e não mais o oposto.

A Abolição jogaria a pá de cal sobre o Império; o fim da escravidão significou também o fim da disposição da cafeicultura paulista em apoiar a Monarquia e, em pouco mais de um ano, veio o golpe militar que instaurou a República.

O Rio era então o maior centro econômico do país, sua principal praça financeira, centro comercial e industrial. Sua população dobrou entre 1872 e 1890 , inflada não só por uma classe de serviços urbana mas também por ex-escravos, além de migrantes internos e estrangeiros - aproximadamente $55 \%$ da população vinha de fora do Rio. As condições de moradia no centro, área mais densa da cidade, eram péssimas. A pressão social levou ao aumento da violência. Nas palavras de Azevedo (2017, p. 80),

\footnotetext{
O individualismo burguês que desprezava os miseráveis que tomavam as ruas da capital tinha contrapartida na ação individualista do ex-cativo, que recorria à criminalidade e prática de biscates para conseguir extrair o necessário à sobrevivência, incerta, de cada dia. O fenômeno da "malandragem" crescia em uma cidade pouco solidária, na qual somente os "espertos" poderiam sobreviver. A dissolução das formas de proteção social da antiga ordem e o crescimento desordenado da urbe faziam do Rio de Janeiro um espaço de consagração do individualismo [...]
}

A essa atmosfera que desprezava a solidariedade, somem-se os efeitos do Encihamento, política monetária implantada por Rui Barbosa, ministro das Finanças, em 1890, que ampliou as concessões para que bancos emitissem moeda. As emissões 
sem lastro geraram uma febre especulativa, graças à facilidade de crédito. Floresceu a ideia de que era possível enriquecer da noite para o dia e que, para ascender socialmente, era preciso ser esperto e aproveitar o momento - era a capital do arrivismo e do smartismo, atitudes que se expandiram na esteira do afrouxamento da austeridade entre poder público e poder privado, a ostentação ganhando espaço crescente na sociedade republicana.

"Uma verdadeira febre de consumo tomou conta da cidade, toda ela voltada para a 'novidade', a 'última moda' e os artigos dernier bateau”, escreve Sevcenko (2003). A essa altura, a imagem do progresso, que o historiador sintetiza como "versão prática do conceito homólogo de civilização" se transforma na "obsessão coletiva da nova burguesia" (SEVCENKO, 2003, pp. 40-2).

É nessa atmosfera que o Clube de Engenharia se alia aos cafeicultores paulistas na consolidação do progresso técnico e material como éthos da República.

Os engenheiros defendiam que as reformas, cuja necessidade a essa altura era clara, não poderiam ficar a cargo de administradores ou juristas, bacharéis em direito ou médicos, que ocupavam os principais cargos públicos então, devendo ser entregues aos homens da racionalidade técnica.

Se os membros do Clube de Engenharia eram os representantes da técnica, os cafeicultores seriam os portadores do progresso material - o café era o sustentáculo da economia do país e, na visão dos fazendeiros paulistas, finda a escravidão, ele deveria ser produzido por mão de obra branca, vinda da Europa, que seria mais produtiva e mais civilizada. O Rio de Janeiro, contudo, não era exatamente um chamariz; as doenças, principalmente a febre amarela, afastavam os estrangeiros - a Itália chegaria a proibir por lei, em 1902, a imigração para o Brasil.

A partir da década de 1890, o Clube de Engenharia se aproximaria da elite cafeeira. Em 1894, Prudente de Morais seria escolhido o primeiro presidente civil da República, inaugurando uma longa hegemonia liberal paulista no cargo. Seria sucedido por Campos Sales (1898), e este, por Rodrigues Alves (1902) - os dois tendo ocupado o governo de São Paulo ao longo dos mandatos presidenciais anteriores aos seus. Unidos, cafeicultores e engenheiros imprimiram ao Rio uma marca simbólica e 
ideológica alheia à tradição que, até ali, havia conformado a cidade. A ideia era fazer da cidade de fato a capital, a representação de um país e de um regime político.

\subsection{Cada cabeça, uma sentença: as duas reformas do centro}

É importante definir as particularidades de Francisco de Paula Rodrigues Alves nesse quadro. Embora fosse um representante da elite paulista - sua família produzia café em Guaratinguetá - era considerado um presidente híbrido, por seu passado monarquista. Embora defendesse o progresso como valor, formou-se bacharel em direito e chegou a ser deputado pelo Partido Conservador no Império. Só se tornou membro do Partido Republicano Paulista com o novo regime já instaurado. É dentro desse arco de valores que se compreende a escolha de Francisco Pereira Passos para prefeito do Rio, um engenheiro que tinha experiência administrativa na cidade e com um ideário de formação, como o do novo presidente, forjado pela mentalidade imperial (AZEVEDO, 2017, pp. 247-9)

É bom lembrar que, entre 1898 e 1902, sob Campos Sales, o Rio de Janeiro teve sete prefeitos. A administração municipal estava, portanto, longe da ordem. A escolha de Pereira Passos, anunciada em 30 de dezembro de 1902, foi de imediato elogiada pela imprensa, que via no engenheiro um quadro técnico, um administrador que não estava ligado a interesses políticos, o que permitiria levar adiante o ambicioso plano de urbanização que fora anunciado por Rodrigues Alves ao tomar posse, em 15 de novembro. Mesmo em Buenos Aires, como vimos, a notícia circulou (BRENNA, 1985, pp.20-1).

Importante também reforçar um aspecto que é muitas vezes esquecido, que é que não houve uma reforma do Rio de Janeiro, mas duas; dois conjuntos de ações de renovação urbana, paralelos e complementares, um no plano federal e outro no plano municipal. As modificações ficaram indistintamente conhecidas como Reforma 
Passos, sobretudo a partir dos anos 1980, quando uma série de estudos historiográficos dedicou-se às mudanças ocorridas na cidade entre 1903 e $19063^{\circ}$.

Se a reforma em seu âmbito municipal ficaria a cargo de um engenheiro de carreira no Estado Imperial, que já havia tentado implantar um plano urbanístico em 1875, a reforma federal ficou a cargo de Lauro Müller, engenheiro militar que aderiu à República, e de Paulo de Frontin, representante típico da geração do Clube de Engenheiros.

A confluência das duas reformas se dá na avenida Central, concebida pelo governo federal como uma obra de infraestrutura portadora do progresso, mas captada pelo projeto municipal como parte de seu plano civilizatório para o centro.

A avenida Central foi pensada inicialmente pela União como via de escoamento para as mercadorias do porto. A renovação portuária, com o aterramento de largas áreas, era a prioridade máxima das obras federais, atendendo às necessidades dos cafeicultores e beneficiando a distribuição de bens importados. Mas a Avenida impôs modificações nas áreas por onde passava, uma vez que o sistema viário ao seu redor, um "dédalo de ruas estreitas, sinuosas e. precariamente calçadas" (BENCHIMOL, 1992, p. 236), não comportava o tráfico que a avenida Central supunha. Essas modificações paralelas na Cidade Velha - alargamento de vias, regulamentação do transporte de carga, entre outras medidas - ficaram sob responsabilidade de Pereira Passos.

Tão forte foi o impacto das modificações sobre a cidade antiga ainda existente no centro que é comum que a historiografia mescle, ao narrar esse período, as

\footnotetext{
30 Durante a banca, tanto a professora Beatriz Resende quanto a professora Lilia Schwarcz ponderaram que havia mais de duas reformas do centro a serem lembradas. Beatriz Resende assinalou a pouca presença de Carlos Sampaio; Lilia Schwarcz mencionou que mais espaço poderia ter sido dado à reforma sanitária. As opções aqui feitas derivam do recorte escolhido para a pesquisa. Pareceu-me importante e pertinente seguir a leitura de André Nunes de Azevedo pelo fato de que as duas reformas a que aludo se deram de forma concomitante e são correntemente tratadas como uma só, quando atendiam a interesses e ideologias diferentes, como exponho aqui, seguindo o pensamento do historiador. A reforma promovida pelo prefeito Carlos Sampaio, que arrasaria o morro do Castelo, um dos locais de fundação da cidade, ocorreu em 1922, ano da morte de Lima Barreto. Como se verá mais adiante, embora este texto mencione a melancólica despedida que o escritor faz de sua velha cidade, mas o cerne de minha leitura do centro na obra de Lima Barreto se apoia nos escritos do Diário íntimo e no romance Vida e Morte de M.J. Gonzaga de Sá. Quanto à reforma sanitária, de inegável importância histórica na medida em que subsidia justificativas para a reforma urbana, ela foi abordada com detenção em obras extensas que tratam deste período, às quais aqui me refiro, em especial o excelente A Revolta da Vacina, de Nicolau Sevcenko, em complemento às observações do próprio Lima Barreto acerca do episódio, ao qual não ficou alheio.
} 
atribuições da União e as da administração municipal. Por exemplo Vera F. Rezende escreve que a abertura da avenida Central foi uma "grande obra a cargo do governo federal”, mas em seguida diz que, para realizá-la, "Pereira Passos esbarra com o problema da população de baixa renda que ali reside e desapropria cortiços, casas de cômodos e pequenos comércios" (REZENDE, 1999, p. 40).

O entendimento das duas reformas como uma só também passa pelo fato de que a gestão da cidade correspondia ao mesmo tempo à União e à prefeitura, "cujas 'burocracias' se superpunham, atuando, muitas vezes, em função de políticas ou determinações conflitantes”, como escreve Jaime Larry Benchimol, dizendo que havia "grande confusão de atribuições em tudo o que dizia respeito a rendas fiscais e à provisão de equipamentos e serviços [...]” (BENCHIMOL, 1992, p. 257).

Conquanto a relação entre Pereira Passos e o governo federal enfrentasse dissensões, os interesses das duas administrações e suas reformas se encontrariam na avenida Central. André Nunes de Azevedo faz uma rica leitura a respeito de como se materializam, no espaço físico da Avenida, os ideais do Clube de Engenheiros, correspondentes aos da União, e o entendimento à moda imperial de Pereira Passos, sempre pensando no díptico progresso e civilização. No início da avenida, junto ao porto, na atual praça Mauá, erguida sobre o antigo largo da Prainha, foi colocada a estátua do barão de Mauá, símbolo do capitalista brasileiro, olhando para o mar, de onde viria o progresso; no outro extremo, na atual Cinelândia, configurou-se um espaço da civilização. Ali, nas imediações do antigo largo da Mãe do Bispo - onde já se concentravam cultura, com o teatro Lírico, e política, com o Conselho Municipal, ambos herdados do Império -, Pereira Passos decidiu instalar o Teatro Municipal. Foi para isso motivado pela proximidade da futura Escola Nacional de Belas Artes, depois do que viria também a nova Biblioteca Nacional - ambas instituições do governo federal - fechando o polo cultural. Coroando tudo, no final da avenida, um obelisco egípcio, como o levado a Paris por Napoleão, o que remetia não só à ideia de evolução das civilizações no tempo mas também a de sua superação pela civilização ocidental, que seria assim o ápice do movimento histórico civilizatório. Essa região fica nas imediações do morro do Castelo, forte memória da cidade colonial, e de edificações históricas como o edifício neogótico do Conselho Municipal, que se inscrevem a tradição cultural da cidade e que Pereira Passos, assim como o morro, insistiu em 
manter de pé, apesar de a opinião pública clamar por sua derrubada, em nome do progresso (AZEVEDO, 2017, pp. 182-9; p. 252).

A leitura dessa setorização da Avenida, na qual Pereira Passos é visto como um urbanizador culturalista - ou seja, que considera a cultura de uma cidade como valor a ser destacado, de forma reverente com suas referências históricas (AZEVEDO, 2017, p. 180) - é uma parte especialmente eficaz da tentativa de André Nunes de Azevedo de reabilitar a imagem do prefeito, que vinha sendo retratado de forma unívoca a partir dos estudos dos anos 1980.

Azevedo refuta ainda - inclusive a partir da análise formal de modificações que propôs, como o desenho das avenidas - a ideia de que ele fosse um Haussmann tropical e um expulsor das populações pobres do centro. Lista os esforços de Pereira Passos para atrair a população para a região central renovada, usando para isso equipamentos como um aquário e apresentações musicais nos coretos, dotando a estrutura urbana de uma função pedagógica de civilizar a população. Além disso, o historiador recupera as propostas do prefeito de construir habitações operárias na região central, que amenizariam o problema de moradia que a cidade enfrentava havia décadas, moradias essas que também cumpririam com sua intenção de civilizar o povo pela vivência do novo centro urbano - embora não aprofunde os motivos pelos quais essas propostas quase não saíram do papel, tendo sido construída apenas uma das vilas (AZEVEDO, 2017, pp. 258-72). Tampouco consegue negar que o conjunto de reformas tenha sido, de fato, um fator gerador de encarecimento fundiário na região central, expulsando a população de menor renda para os subúrbios - o que no entanto relega a nota de rodapé (AZEVEDO, 2017, p. 177).

Outro aspecto que o historiador destaca ao tentar traçar um perfil mais nuançado de Pereira Passos é o fato de que, pela reestruturação viária proposta pelo prefeito, seria possível dizer que ele teve uma visão organicista da cidade, isto é, vendoa como um corpo, em que os órgãos devem funcionar de maneira integrada (AZEVEDO, 2017, p. 176).

Mas a visão cheia de boa vontade de Azevedo não é a que prevalece na historiografia sobre Pereira Passos. Veja-se por exemplo a de Paulo César Garcez Marins, para quem a abertura de vias, em vez de integrar, tem um viés segregador, facilitando a criação de bolsões de homogeneidade. Para o historiador, a ideia era que 
se criasse "uma geografia da exclusão e segregação social, que acabasse separando em bairros distintos os diversos segmentos da sociedade” (MARINS, 1998, p. 136):

Privacidade, portanto, não poderia mais confundir-se com domesticidade, com os simples limites da casa, mas escapava para uma dimensão que abarcava os convívios com os vizinhos - todos sujeitos a uma mesma gramática de comportamento. Harmonizando-se as vizinhanças facilitava-se o conhecimento da fisiologia urbana - e das múltiplas "disfunções" geradas nas clivagens sociais altamente tensionadas nas capitais brasileiras, sobretudo após a concentração de grandes massas populacionais nas cidades já na primeira década republicana.

Para Marins, um fato que Azevedo destaca entre os positivos - ter pensado a expansão para o Leme e Copacabana, conseguindo que a Companhia de Carris do Jardim Botânico construísse o túnel com o qual se havia comprometido em gestão anterior, inaugurado em 1906 - é mais uma etapa desse pensamento segregador (MARINS, 1998, p. 148), pois a

migração das elites para os bairros ao sul da cidade assegurava-lhes distância da 'promiscuidade' das áreas centrais e das adjacências do palácio imperial de São Cristóvão", onde muitas residências outrora distintas haviam sido transformadas em casas de cômodos, ou avizinharam-se às indústrias que se instalavam na região. Mesmo a moradia dos mortos elegantes debandava dos antigos cemitérios terceiros do Caju e Catumbi, inseridos em bairros claramente populares, para o Cemitério São João Batista, no Botafogo, com sua vizinhança sofisticada.

Por fim, frisa ainda André Nunes de Azevedo, Pereira Passos planejou também ligações entre diversos bairros suburbanos, além de ter sido o primeiro a "dar formato de ruas aos caminhos do subúrbio carioca, construindo sarjetas e colocando bueiros em várias localidades dos arrabaldes da cidade” (AZEVEDO, 2017, p. 176-7). Este aspecto é interessante e nos permite voltar ao início deste capítulo, no qual dizíamos que, enquanto o centro da cidade estava se remodelando, Lima Barreto iniciava sua vida suburbana.

Em mais de uma crônica o escritor deu fé do que diz Azevedo quanto ao cuidado viário que Pereira Passos teve nos subúrbios - ainda que o tenha feito por oposição, 
recordando, anos depois de sua reforma, ruas nas quais o macadame nunca foi refeito em décadas ${ }^{3}$.

À luz do que já sabemos sobre Lima Barreto e a partir das ideias aqui reunidas acerca das noções de progresso e civilização, pode-se dizer, de maneira muito breve, que o escritor era um homem mais pautado por um ideal civilizatório à moda do Império, ou seja, de civilização como uma finalidade comum que se alcançaria gradativamente e, importante, de maneira adequada ao nosso país, sem concessões ao cosmopolitismo. Ele também se mostrava particularmente avesso a signos do individualismo que caracteriza a República, fomentando o ideal do progresso técnico e material32. Em resumo, não se entendia com o éthos republicano, e as razões residem tanto no trauma familiar quanto com a falta de solidariedade que associa ao regime.

Como foi dito mais acima, as críticas ao abandono dos subúrbios se incrementam, na obra de Lima Barreto quando ele tem sua rotina mais limitada a Todos os Santos, num período em que as atenções estavam concentradas na expansão imobiliária para a zona sul e no arrasamento do morro do Castelo para a exposição do Centenário da Independência, em 1922.

Quanto a suas observações a respeito das modificações no centro da cidade e suas consequências, inclusive na vida social, essas seriam temas abordados com mais regularidade, sobretudo em crônicas, quando ele começasse a ocupar com mais frequência espaços na imprensa.

Mas, se nas crônicas, pelo próprio caráter e brevidade dos textos, as observações tendem a ser pontuais, é em uma obra de ficção que ele faz sua elegia à cidade que se perdia diante dos olhos de todos. Vida e morte de M.J. Gonzaga de Sá seria seu último

${ }^{31}$ São exemplos as crônicas nas quais narra as dificuldades de chegar ao cemitério de Inhaúma, o que deve ter motivado sua simbólica decisão de ser enterrado no São João Batista. Ver "História macabra", Careta, 17.jul.1915 (BARRETO, 2004, p. 221-2, vol. 1) e "Queixa de defunto", Careta, 20.mar.1920 (BARRETO, 2004, pp. 157-8, vol. 2). Em "O prefeito e o povo", Careta, 15.jan.1921 (BARRETO, 2004, pp. 294-6, vol. 2), na qual questiona as prioridades da administração municipal, também reclama do calçamento a atrapalhar o caminho ao cemitério suburbano - nem depois de mortos os moradores dali tinham sua dignidade contemplada pela prefeitura.

$3^{2} \mathrm{O}$ telefone, que acha uma inutilidade, é um exemplo e motiva ao menos três crônicas: "A questão dos telefones”, Careta, 9.abr.1921 (BARRETO, 2004, pp. 344-5, vol.2), reformulação de outra publicada antes sob pseudônimo de Horácio Acácio, "A menina do telefone", Careta, 27.set.1919 (BARRETO, 2016, pp. 260-1); e, por fim, citando mais lateralmente as mesmas "meninas namoradeiras" que usam de graça os aparelhos de estabelecimento comerciais e motivaram os textos anteriores, "O telefone e seu inventor", Careta, 26.ago.1922 (BARRETO, 2004,pp 549-50, vol.2). 
romance publicado em vida, embora as primeiras anotações sobre o livro em seu diário datem de 1906 - ao enviar os originais para publicação daquele que viria a ser seu primeiro romance, Recordações do escrivão Isaías Caminha, em 1909, seu primeiro romance, afirma em carta ao crítico Gonzaga Duque33 que o teria preferido como livro de estreia ao “cerebrino” e “pouco acessível” Gonzaga de Sá (apud BARBOSA, 2017, p. 172).

Seu Gonzaga de Sá é, também ele, um homem do Império, vendo nascer uma cidade regida por valores que não eram os seus.

\subsection{O vagar dos amanuenses}

Lima Barreto inicia seu diário em 1900, com notas sobre a Escola Politécnica, escritas de forma romanceada. Dos anos de 1901 e 1902, não há nada. As anotações pessoais são retomadas em 1903, com uma apresentação brevíssima de quem era e do que pretendia ser (BARRETO, 1961, p. 33).

Eu sou Afonso Henriques de Lima Barreto. Tenho vinte e dois anos. Sou filho legítimo de João Henriques de Lima Barreto. Fui aluno da Escola Politécnica. No futuro, escreverei a História da Escravidão Negra no Brasil e sua influência na nossa nacionalidade.

Nasci em segunda-feira, 13-5-81.

O meu decálogo:

1- Não ser mais aluno da Escola Politécnica.

2- $\quad$ Não beber excesso de cousa alguma.

$3-\quad$ E...

33 BARRETO, Lima. Correspondência ativa e passiva. São Paulo: Brasiliense, 1956, pp. 169-70, vol. I. 
O futuro escritor por essa altura dava aulas particulares para se manter e no diário vemos que passava aperto para comer esperando um "futuro de glória" (BARRETO, 1961, p. 33); registra alguns apontamentos cotidianos e esboça um curso autodidático de filosofia. Sabemos que, ao contrário do que pretendia deixar como legado, não escreveu sua história da escravidão34. De seu decálogo inacabado, o jovem Afonso conseguiria cumprir o primeiro propósito, embora não da maneira como talvez pretendesse; afundou, para sua grande desgraça, no segundo; e muito possivelmente desconsiderou quantas coisas imprevistas poderiam se esconder nas reticências do terceiro.

Há uma anotação de caráter semelhante em 1905. A 30 de janeiro, ele diz que, se conseguisse saldar as dívidas do pai e cercá-lo da abundância à qual ele tinha direito - ou seja, após cumprir seu dever filial -, só pedia três coisas: Um amor/ Um belo livro/ E uma viagem pela Europa e pela Ásia (p. 96). Lima Barreto nunca teve um relacionamento amoroso; nunca saiu do país e só brevemente se ausentou do Rio de Janeiro; escreveu furiosamente e publicou vários livros, chegando a ser conhecido mas o que ele teria querido exatamente dizer com "belo", a essa altura, não nos é dado saber, a fim de avaliarmos se ele teria cumprido esse desejo de acordo com suas aspirações de juventude.

É melancólico observar esse tipo de notas. E, se não faremos a partir das anotações uma leviana análise psicológica do escritor, elas servem para que tentemos ao menos nos colocarmos no lugar de Lima quando começa sua amarga carreira de funcionário, no fim de 1903, e vermos como ela passa a influir na sua vida pessoal.

São dedicadas a isso as primeiras frases de 1904: "Dolorosa vida a minha! Empreguei-me e há três meses vou exercendo as minhas funções. A minha casa ainda é aquela dolorosa geena pra minh'alma. É um mosaico tétrico de dor e tolice" (BARRETO, 1961, p. 41).

Inextricavelmente ligados estão o inferno doméstico e o exercício de suas funções. Desde o princípio, claro está, Lima não via com boa vontade o trabalho na

34 Gilberto Freyre observa no prefácio ao Diário Íntimo que ele seria o autor dessa obra: "escrevi a meu modo o livro que ele mais desejou escrever" (BARRETO, 1961, p. 10). A observação não deixa de soar maldosa de parte do autor de Casa-grande e senzala, uma vez que seu prefácio se calca na dor da questão racial na obra de Lima Barreto e na falta de justo reconhecimento que o estimulasse. 
Secretaria da Guerra. Era um meio de compor a receita com os rendimentos do pai e a magra contribuição do irmão Carlindo para sustentar sua família e a de Prisciliana desse grupo de agregados, não esperava nada, eram "aquilo de sempre”. "Sem a distinção da cultura nossa, sem o refinamento que já conhecíamos, veio em parte talvez prender o desenvolvimento superior dos meus. Só eu escapo!”35.

A primeira das várias anotações que fará sobre a secretaria aparece no passado: "Quando eu fui amanuense da Secretaria da Guerra pintou-se (em 904) a secretaria e dependência [...]”. A formulação com o verbo no passado trai seu desejo de sair dali e se repetiria em outros momentos naquele ano.

As notas que Lima tomava a respeito de seus colegas e superiores logo se desdobrariam nos seus escritos ficcionais. Quem sabe se por temor a perder o detestável ganha-pão tenha mantido seu Vida e morte de M. J. Gonzaga de Sá inédito até 1919, para publicá-lo já aposentado, preferindo estrear como escritor com um romance em que o alvo principal da crítica era a grande imprensa - outra forma de poder contra a qual assestaria sua mira, conforme assinalamos com Nicolau Sevcenko (2003, p. 201) no capítulo anterior - não sem pagar o preço.

O romance publicado em 1919 se inicia com uma advertência, que reproduzimos abaixo, na qual Lima Barreto se coloca como personagem, firmada a abril de 1918 (BARRETO, 2017e, p. 51)36.

Encarregou-me o meu antigo colega de escola e, hoje, de ofício, Augusto Machado, de publicar-lhe esta pequena obra. Antes me havia ele pedido que a

\footnotetext{
35 Lima faz outras anotações desgostosas acerca da família de Prisciliana e de como essa presença, a seu ver, exercia uma má influência sobre seus irmãos. Em si próprio, como se vê, tinha esperança. Acreditava em sua diligência e em seu espírito crítico, que não via nos irmãos, que por isso estariam ameaçados por essa exposição. Veja-se este exemplo, que não é o único, na entrada de 3 de janeiro de 1905, no qual se queixa da influência sobre sua irmã, Evangelina, exercida por Paulina, "vulgar mulatinha, muito estúpida, cheia de farofas de beleza e de presunção [...], vulgar, chata como um percevejo, e a meu pai nunca perdoarei essa sua ligação com essa boa negra Prisciliana, que grandes transtornos trouxe a nossa vida". "Eu, entretanto, penso me ter salvo." Reclama que, não consegue transmitir no trato pessoal a simpatia que tem pela "gente pobre do Brasil, especialmente pelos de cor" e que os que com ele vivem não reconhecem sua superioridade, não o respeitando ou obedecendo. "O filho da tal negra despediu-se do emprego em que o pus para ficar em casa escrevendo versos." Consciente da virulência do escrito, justifica-se em seguida, pensando na posteridade de suas notas, esperando que, caso viessem a público após sua morte, quem se servisse delas o fizesse com "máximo cuidado e discrição", pois "mesmo no túmulo” poderia ter vergonha (BARRETO, 1961, pp. 75-7).
}

${ }^{36}$ Lima havia usado do recurso também na segunda edição de Recordações de Isaías Caminha, lançada em 1917 por ele mesmo. 
revisse. Se bem que nela nada encontrasse para retocar, não me pareceu de rigor a classificação de biografia que o meu amigo Machado lhe deu.

Faltam-lhe, para isso, a rigorosa exatidão de certos dados, a explanação minuciosa de algumas passagens da vida da principal personagem e as datas indispensáveis em trabalho que queira ser classificado de tal forma; e não só por isso, penso assim, como também pelo fato de muito aparecer e, às vezes sobressair demasiado, a pessoa do autor.

Aqui e ali, Machado trata mais dele do que do seu herói.

Julgando que tão insignificantes defeitos eram de desprezar em presença dos reais méritos de pequeno livro, apressei-me em conseguir a sua publicação, certo de que, com isso irei animar uma acentuada vocação literária que se manifesta, de modo inequívoco, nas páginas que se seguem.

De fato, Vida e Morte de M. J. Gonzaga de Sá é bem como descreve Lima ao vestir-se de editor na ficção, como se verá mais adiante; menos uma biografia do que as recordações de Machado sobre o amigo, os momentos compartilhados na repartição e nas ruas. Mais que tudo, é um retrato da cidade, no qual se entrelaçam o presente vivido e o passado recordado por Gonzaga de Sá.

À "Advertência” segue-se a "Explicação necessária” de Augusto Machado, na qual o narrador faz troça de Pelino Guedes, que Lima tinha como desafeto desde o episódio da aposentadoria do pai, do gramático Cândido do Lago e de seu professor Licínio Cardoso. Aproximam-se, por esses primeiros traços, narrador e autor, além da profissão, como já informava a "Advertência".

No texto, Augusto Machado diz que "era fácil ver que [...] forçoso era que houvesse um biógrafo para os ministros e outro para os amanuenses" (BARRETO, 2017e, p. 53). Com isso aprendemos que também Gonzaga de Sá tinha a profissão de Lima Barreto e do narrador - Gonzaga de Sá a exerce na fictícia Secretaria dos Cultos, onde Augusto Machado vai dar a fim de resolver uma questão referente ao número de tiros de salva que deveriam ser empregados para receber um bispo - a ação começa com um retrato das questiúnculas que Lima entende ocuparem os funcionários da nação.

No primeiro capítulo - em meio a um belíssimo devaneio a partir da descrição da paisagem, na qual podemos ver a mão que Lima treinara em suas observações no diário - aprendemos que o narrador, como o escritor, tem origens mestiças. Mais do que isso, Augusto Machado faz uma espécie de síntese na qual entende ser o legítimo homem daquela terra (BARRETO, 2017e, p. 65). 
E, assim, fui sentindo com orgulho que as condições de meu nascimento e o movimento de minha vida se harmonizavam - umas supunham o outro que se continha nelas; e também foi com orgulho que verifiquei nada ter perdido das aquisições dos meus avós, desde que se desprenderam de Portugal e da África. Era já o esboço do que havia de ser, de hoje a anos, o homem criação deste lugar. Por isso, já me apoio nas cousas que me cercam, familiarmente, e a paisagem que me rodeia não me é mais inédita: conta-me a história comum da cidade e a longa elegia das dores que ela presenciou nos segmentos de vida que precederam e deram origem à minha.

O trecho sintetiza também o que é o livro. Ao fazer essa constatação, Augusto Machado está à espera de Gonzaga de Sá no Passeio Público, de onde contempla o mar, esse mesmo mar que trouxe seus antepassados e que, diz o narrador, ele sempre gosta de observar (BARRETO, 2017e, pp. 61-2). O encontro seria o último. Depois de subir “a pé e pelo caminho mais longo" até Santa Teresa, onde fica a casa de Gonzaga de Sá, à qual se encaminham para jantar, observando as ruas, construções e a vista, o velho amigo se abaixa, diante de sua casa, para colher uma flor e dá-la ao jovem - "mas caiu, e morreu” (BARRETO, 2017e, pp. 67) . Dessa forma sintética, entremeada à paisagem da cidade, entra a morte de Gonzaga de Sá, no primeiro capítulo do livro. A partir daí, veremos como se conformou a relação entre mestre e aluno, que vista em retrospecto, permitiu que Augusto Machado construísse sua consciência de homem pertencente àquela cidade - ainda que os fatos e as mudanças, e isso não é dito, mas sugerido, o pudessem querer expulsar.

No romance, Gonzaga de Sá é introduzido, pelos olhos de Machado, como um homem cuja figura emana respeitabilidade (BARRETO, 2017e, p. 60); de forma fantasiosa, Augusto Machado adivinha as origens ancestrais do futuro amigo:

Vi logo nele um velho inteligente, de amplo campo visual a abranger um grande setor da vida; entendi-o ilustrado e de uma recalcada bondade. Não sei também por que adivinhei que tinha um bom nascimento e a antiguidade do aparecimento dos seus antepassados nestas terras não datava da República nem do encilhamento.

Em sua apresentação à obra, Marcos Scheffel observa a presença marcante de funcionários públicos na ficção nacional, sobretudo a partir dos anos 1930. Nessas 
obras, o funcionário aparece sempre como o decaído - o personagem conformando-se com uma posição pior do que a que poderia ocupar - ou o derrotado - a expectativa é depositada no serviço público, mas este o joga para uma posição periférica. Scheffel identifica em Lima Barreto um precursor dessa corrente, lembrando que há, em sua ficção, profusão de ambos os tipos (SCHEFFEL, 2017e, pp. 26-7). Gonzaga de Sá, assim como Policarpo Quaresma, seria um decaído. "Os dois”, escreve Scheffel, "ocupam posições humildes na máquina do governo e ambos têm paixão pelo conhecimento, pelos estudos - fato que gera o riso, o escárnio e a chacota dos colegas de repartição" (SCHEFFEL, 2017e, p. 28).

Em ambos, há o questionamento com relação à extensão de suas ações na sociedade: "Gonzaga acha que deveria ter agido mais; Quaresma acha que não deveria ter agido". Tanto um quanto outro são contemplados por narradores que os admiram e que constatam que, se "não 'venceram' dentro do funcionalismo" é porque, "para subir teriam que descer enquanto indivíduos". A derrota não se deve, pois, aos personagens, mas ao meio "hostil, competitivo e medíocre" no qual se inseriam, sendo o serviço público, nas obras do escritor, "um microcosmo dos desmandos dos nossos primeiros anos da República” (SCHEFFEL, 2017e, pp. 28-9).

Por sua parte, R. J. Oakley lê os personagens de Gonzaga de Sá e Augusto Machado à luz do conceito de "herói intelectual", introduzido por Victor Brombert37. Conforme explica Oakley, Brombert vê na prosa francesa finissecular a figura do homem que, "frequentemente inadaptado e às voltas com a sociedade circundante, sente a premente necessidade de agir, enquanto simultaneamente receia que agir seja um gesto fútil" (OAKLEY, 2011, p. 86). Partindo do fato de que esse herói estaria presente na obra de Anatole France, um dos autores de culto de Lima Barreto, Oakley identifica personificações do conceito nos protagonistas de Recordações do escrivão Isaías Caminha e Vida e morte de M.J. Gonzaga de Sá. Policarpo Quaresma, em contrapartida, seria o "intelectual atuante", o herói não meramente contemplativo (OAKLEY, 2011, pp. 87).

A atitude contemplativa, contudo, não tem uma só forma.

37 The Intellectual Hero: Studies in the French Novel, 1880-1955. Philadelphia: J.P. Lippincott, 1961. 
Isaías Caminha, no início de sua narrativa, é um jovem de província que teme o Rio, "uma cidade grande, cheia de riqueza, abarrotada de egoísmo" onde não tinha ninguém que lhe pudesse valer (BARRETO, 2017d, p. 69), mas que se lança à aventura da metrópole para tentar se fazer doutor. Sua primeira visão da cidade é decepcionante. "Aquela praça inesperadamente feia, fechada em frente por um edifício sem gosto, ofendeu-me como se levasse uma bofetada.” (BARRETO, 2017d, p. 82) Mais tarde, porém, sem negar seu provincianismo, é absorvido pela experiência moderna de perder-se na multidão (BARRETO, 2017d, p. 103):

Subia a rua. Evitando os grupos parados no centro e nas calçadas, eu ia caminhando como quem navegava entre escolhos, recolhendo frases soltas, ditos, pilhérias e grossos palavrões também. Cruzava com mulheres bonitas e feias, grandes e pequenas, de plumas e laçarotes, farfalhantes de sedas; eram como grandes e pequenas embarcações movidas por um vento brando que lhes enfunasse igualmente o velame. Se uma roçava por mim, eu ficava entontecido, agradavelmente entontecido dentro da atmosfera de perfumes que exalava. Era um gozo olhá-las, e elas e à rua, com sombra protetora, marginada de altas vitrinas atapetadas de joias e de tecidos macios.

Parava diante de uma e de outra, fascinado por aquelas coisas frágeis e caras. As botinas, os chapéus petulantes, o linho das roupas brancas, as gravatas ligeiras pareciam dizer-me: "Veste-me, ó idiota! nós somos a civilização, a honestidade, a consideração, a beleza e o saber. Sem nós não há nada disso; nós somos, além de tudo, a majestade e o domínio!”.

Isaías, no Rio, sente-se desprotegido. "Eu era como uma árvore cuja raiz não encontra mais terra em que se apoie e donde tire vida; era como um molusco que perdeu a concha protetora e que se vê a toda a hora esmagado pela menor pressão" (BARRETO, 2017d, p. 107). Como aponta Carmem Lúcia Negreiros de Figueiredo, Isaías é como um "espectador das ruas"; "a mistura de sentimentos pessoais e a observação davam, ao estar em público, o conteúdo ao mesmo tempo, de uma experiência pessoal e passiva" (FIGUEIREDO, 1995, p. 77).

Lima Barreto inscreve seu Isaías recém-chegado ao Rio no rol daqueles personagens dos romances franceses que deixam a província tacanha para se perderem na metrópole dissoluta, dos quais falávamos mais acima. Sua atitude irá mudar conforme se deixe absorver, e corromper, pela vida na metrópole, em sua experiência no jornal $O$ Globo, à moda do Lucien Chardon das Ilusões perdidas de Balzac. “Aos poucos, esqueci-me dos dias de fome passados a deambular pelas ruas da cidade”, recorda Isaías (BARRETO, 2017d, p. 194). 
A atitude contemplativa de Gonzaga de Sá, apreendida e aprendida por seu discípulo Augusto Machado nos passeios que dão juntos e que compõem o cerne do romance, parte de uma relação completamente distinta com o meio. Ele está em seu elemento desde o berço e preza sua relação com a cidade de cujos fundadores descende - Estácio de Sá, que a fundou em 1565, e Mem de Sá, seu tio, governador-geral do Brasil, que dois anos mais tarde determinaria a transferência da cidade para o morro do Castelo, a fim de melhor a defender do cerco francês à baía de Guanabara. Em um dos passeios, no trem "dos de Petrópolis", para chegar à estação de Bonsucesso, rumo ao Engenho da Penha, localidade que Augusto Machado não conhecia, a dupla mudase da primeira para a segunda classe. O velho explica ao moço por que não quis ficar onde estava (BARRETO, 2017e, p. 83):

Fugi dessa gente de Petrópolis, porque, para mim, eles são estrangeiros, invasores, as mais das vezes sem nenhuma cultura e sempre rapinantes, sejam nacionais ou estrangeiros. Eu sou Sá, sou o Rio de Janeiro, com seus tamoios, seus negros, seus mulatos, seus cafuzos e seus "galegos" também...

Na voz de Gonzaga de Sá está a de Lima Barreto, falando contra o cosmopolitismo que alija o brasileiro do Brasil. Enquanto Isaías via nas lojas da cidade as vitrines, com produtos estrangeiros ou de ares estrangeiros, a gritar "somos a civilização", Gonzaga de Sá evoca a raiz mestiça do seu Rio - aquela que as "picaretas regeneradoras" saudadas por Bilac iam pondo abaixo.

Quando vai pelas ruas, Gonzaga de Sá não se deixa levar pela multidão como Isaías Caminha; ele se põe à parte, como se aquela cidade não fosse a sua, ou como se aquela gente a ela não pertencesse. Seu caminhar tem outro ritmo; não há nele o "passo inglês" do Jacques Pedreira de João do Rio, o "hábito inovador de caminhar pelas ruas sozinho e às pressas", também chamado de "andar à americana". Tampouco o carrega a "curiosidade escrutinadora do flâneur", atraída pela novidade (SEVCENKO, 1998, pp. 550-1). Gonzaga de Sá contempla o presente através do passado, contrapondo um tempo a outro. Eis como Augusto Machado define a relação de Gonzaga de Sá com a rua, na abertura do capítulo V, apropriadamente chamado "O Passeador" (BARRETO, 2017e, p. 87) 
O que me maravilhava em Gonzaga de Sá era o abuso que fazia da faculdade de locomoção. Encontrava-o em toda parte, e nas horas mais adiantadas. Uma vez, ia eu de trem, vi-o pelas tristes ruas que marginam o início da Central; outra vez, era um domingo, encontrei-o na Praia das Flechas, em Niterói. Nas ruas da cidade, já não me causava surpresa vê-lo. Era em todas, pela manhã e pela tarde. Segui-o uma vez. Gonzaga de Sá andava metros, parava em frente a um sobrado, olhava, olhava e continuava. Subia morros, descia ladeiras, devagar sempre, e fumando voluptuosamente, com as mãos atrás das costas, agarrando a bengala. Imaginava, ao vê-lo nesses trejeitos, que, pelo correr do dia, lembrava-se do pé para a mão: como estará aquela casa assim, assim, que eu conheci em 1876? E tocava pelas ruas em fora para de novo contemplar um velho telhado, uma sacada e rever aquelas fisionomias que já mais não são objeto... Não me enganei. Gonzaga de Sá vivia da saudade da sua infância gárrula e da sua mocidade angustiada. Ia em procura de sobrados, das sacadas, dos telhados, para que à vista deles não se lhe morressem de todo na inteligência as várias impressões, noções e conceitos que essas cousas mortas sugeriram durante aquelas épocas de sua vida.

Eis que Gonzaga de Sá, se formos acompanhar a enumeração das formas de caminhar que seguíamos mais acima, demonstra o "envolvimento afetivo com a paisagem urbana, típico da dérive" (SEVCENKO, 1998, pp. 550-1); as "fisionomias" das construções “já mais não são objeto”. Nesse movimento de associar a certos locais determinados momentos de sua vida, entrelaça sua história e a da cidade. Com que desgosto, conta Augusto Machado, o amigo não tinha tentado repetir em vão um acontecimento da infância (BARRETO, 2017e, p. 88).

Um dia faltou à repartição (contou-me isso mais tarde) para contemplar, ao sol
do meio-dia, um casebre do Castelo, visto cinquenta e tantos anos atrás, em
hora igual, por ocasião de uma gazeta da aula primária. Pobre Gonzaga! A casa
tinha $\quad$ ido abaixo.

Augusto Machado diz que o amigo ama a cidade por inteiro - "exceto os subúrbios, que ele não admitia como cidade nem como roça, a que amava também com aquele amor de cousa de arte com que os habitantes dos grandes centros prezam as coisas do campo". Define Gonzaga de Sá como um "historiador artista”, que com "memória muito plástica" fala das "coisas velhas da cidade, principalmente os episódios tristes e pequeninos", fazendo história oral como os poetas da Idade Média faziam epopeias (BARRETO, 2017e, p. 88).

Ainda em "O Passeador”, Gonzaga de Sá tece uma longa explanação sobre a topografia do Rio de Janeiro e como ela determinou as formas da cidade. A aula sobre os morros vem em resposta a uma observação de Machado, qualificando o Rio como 
"estrambótico", dizendo que, espalhado como era, ainda que se estendesse e aumentasse sua população, nunca teria o "aspecto de uma grande capital, movimentada densamente" (BARRETO, 2017e, p. 88).

"Pense que toda a cidade deve ter sua fisionomia própria. Isso de todas se parecerem é gosto dos Estados Unidos; e Deus me livre que tal peste venha a pegarnos", responde Gonzaga de Sá. Lima Barreto mostra, então, nas palavras de Gonzaga de Sá, seu conhecimento acerca dos morros da cidade e dos desafios que eles impõem - "ainda é difícil e demorado ir-se do Méier a Copacabana; gastam-se quase duas horas" -, mas nada, diz o mestre, que "o aperfeiçoamento da viação, abertura de túneis etc.” não viesse a resolver (BARRETO, 2017e, pp. 88-9).

O Rio, segue Gonzaga de Sá, não foi edificado a régua, mas de forma espontânea. "Se não é regular com a estreita geometria de um agrimensor, é, entretanto, com as colinas que a distinguem e fazem-na ela mesma." Depois, fala da fundação da cidade e, ao fazê-lo, localiza o berço da cidade no morro do Castelo (BARRETO, 2017e, p. 90).

\footnotetext{
Ao nascer, no topo do Castelo, não foi mais do que um escolho branco surgindo num revolto mar de bosques e brejos. Aumentando, desceu pela venerável colina abaixo; coleou-se pelas várzeas em ruas estreitas. A necessidade da defesa externa, de alguma forma, obrigou-as a ser assim e a polícia recíproca dos habitantes contra malfeitores prováveis fê-las continuar do mesmo modo, quando, de piratas, pouco se tinha a temer.
}

Não será sem motivo que Lima situe a fundação no Castelo; se ela foi concebida em outro lugar, foi ali que nasceu. O morro, como sabemos, estava desde o século XIX ameaçado de destruição e já aparecera, na narrativa, como um lugar dos afetos de Gonzaga de Sá, que buscou na visita ao morro recuperar sua meninice. No trecho o velho explica também por que eram estreitas as ruas - numa estratégia de defesa. Não o diz, mas é como se censurasse, no alargamento das ruas do centro, o apagamento da história de uma cidade que se fez sem quadrícula graças às "vicissitudes sociais" (BARRETO, 2017e, p. 90) que a conformaram.

O trecho ressoa de forma interessante na crônica "Megalomania", publicada na revista Careta a 28 de agosto de 1920. Nela, Lima censura as "reformas suntuárias na cidade". Reclama da construção de um "prado de corridas no Leblon", como se a "função primordial dos poderes públicos, sobretudo o municipal" fosse "fornecer 
passatempos a quem já os tem de sobra” (BARRETO, 2004, p. 207, v. 2), sem se preocupar com os que não têm onde viver.

Tudo delira e todos nós estamos atacados de megalomania. De quando em quando, dá-nos essa moléstia e nós nos esquecemos de obras vistas, de utilidade geral e social, para pensar só nesses arremedos parisienses, nessas fachadas e ilusões cenográficas.

Não há casas, entretanto queremos arrasar o morro do Castelo, tirando habitação de alguns milhares de pessoas.

Como lógica administrativa, não há cousa mais perfeita!

O mundo passa por tão profunda crise, e de tão variados aspectos, que só um cego não vê o que há nesses projetos de loucura, desafiando a miséria geral.

Remodelar o Rio! Mas como? Arrasando os morros... Mas não será mais o Rio de Janeiro; será toda outra qualquer cidade que não ele.

Em outros escritos, mais para o fim da vida, criticaria a relação da engenharia local com a natureza, caso por exemplo da crônica "O Jardim Botânico e suas palmeiras”. Publicada na Tudo a 26 de junho de 1919 (BARRETO, 2004, pp. 527-9, vol.1), ela reúne boa parte das objeções que o escritor faria nesse sentido.

"Essas gentes novas, e o espírito frívolo delas, que têm ultimamente invadido este meu Rio de Janeiro, vão, aos poucos, matando o que ele tinha de verdadeiramente belo", inicia ele (BARRETO, 2004, pp. 527, vol.1).

Depois de criticar a escolha de materiais das construções, que iam abrindo mão do legítimo granito carioca - na avaliação de Lima, porque este enegrecia com o tempo —, passa a falar do expansionismo rumo à zona sul (BARRETO, 2004, pp. 527-9, vol.1).

Por panurgismo, todos eles foram morar em Botafogo, e de Botafogo para Copacabana, encaminhando para aí todos os seus esforços e verbas municipais de melhoramentos; e os outros, cariocas ou não, panurgianos ricos, vão para lá docilmente, ovinamente. Seguem o tinido da campainha da "madrinha"...

É incrível que, tendo a natureza nos dado uma baía abrigadíssima e terras e terras para construir cidades sob seu abrigo, fôssemos nós continuar e aumentar o que temos, sob o açoite constante dos impiedosos ventos do sul. $[\ldots]$

A nossa burguesia republicana é a mais inepta de todas as burguesias. Não tem gosto, não tem arte, não possui o mais elementar sentimento da natureza. [...] 
É por isso que ela se está amontoando nas praias de fora da barra, construindo casas em cima de areias e restingas, sob o açoite dos ventos implacáveis e fortes, onde não poderão medrar pujantes as grandes fruteiras, mangueiras, jaqueiras, cajazeiros, que são ainda o encanto das velhas chácaras que herdamos da burguesia titulada do Império e mesmo da Colônia.

Só nos parágrafos finais vai falar do Jardim Botânico, "um dos recantos mais belos do Rio, com suas palmeiras hieráticas", que está esquecido. "Ninguém mais vai lá; ninguém mais fala nele. As crônicas elegantes das praias não têm uma palavra de saudade para aquele canto do Rio, tão belo [...]” (BARRETO, 2004, pp. 528, vol. 1).

Conclui de maneira retumbante, dizendo que a "panurgiana burguesia atual voltará ao nada; e as palmeiras do jardim - estou bem certo - ainda hão de tornar a ser a guarda de honra imperial, perfilada em continência, aos que forem sacrificar no templo da Deusa, filha do Mar e da Praia...” (BARRETO, 2004, pp. 529, vol. 1)38.

Falaria também da mania dos aterros, que já aparecera na narrativa que Gonzaga de Sá faz no capítulo "O Passeador" - "a velha São Sebastião aterrou apressada alguns brejos, para aumentar e espraiar-se, e todo material foi-lhe útil para tal fim" (BARRETO, 2017e, p. 90).

Na crônica "A revolta do mar", publicada na Careta a 23 de julho de 1921 (BARRETO, 2004, pp. 383-4), vale-se da prosopopeia para dizer que o mar, qual um deus, não aceitava o desaforo de ser invadido - o tema era uma ressaca que destruíra boa parte da avenida Beira-Mar, ela mesma uma espécie de caminho cenográfico planejado por Pereira Passos para integrar a natureza ao traçado urbano (AZEVEDO, 2017, pp. 276-7).

O Castelo a partir do qual, na narrativa de Gonzaga de Sá, o Rio crescera organicamente, em pouco tempo ruiria para criar um espaço novo, mais cenográfico impossível - o terreno para a exposição do Centenário da Independência. O local onde a cidade se resguardou e de onde se espraiou, galgando a topografia, morro atrás de

\footnotetext{
${ }^{38}$ As árvores são um recorrente tropo para o passado imperial em Lima Barreto. Em crônicas, ele as veria sempre ceifadas pelo progresso. Ele fala de velhos cedros e de pomares, que davam fruta-pão para se comer com manteiga - "O cedro de Teresópolis", 27.fev.1920 (BARRETO, 2004, pp. 129-31, vol. 2); lembraria também um velho tamarineiro - "A derrubada", Correio da Noite, 31.dez.1914 (BARRETO, 2004, pp. 133-4, vol. 1) -, bem como recordaria a destruição de "anosas mangueiras" - "Meditem a respeito" (BARRETO, 2016, pp. 337-40). Em Vida e morte de M.J. Gonzaga de Sá, aliás, as árvores aparecem como "mangueiras maravilhosas" que "viram Dom João VI", na Ilha do Governador e no Fundão. Essas sobreviviam ao homem ainda no tempo da narrativa em que Gonzaga de Sá leva Augusto Machado ao Engenho da Penha - salvo "as que o raio pôs abaixo" (BARRETO, 2017e, p. 82).
} 
morro, arrasado para receber os pavilhões de todo o mundo, mostrando as novidades do progresso e da civilização. Como mais tarde diria Lima em "Literatura militante" não temos nenhum passado, só futuro (BARRETO, 2017a, p. 129).

Considerando que Vida e Morte de M. J. Gonzaga de Sá é um dos primeiros trabalhos que ele inicia, fica muito claro que Lima Barreto tinha desde jovem convicções bem assentadas a respeito da cidade e de sua reformulação.

Nos capítulos sétimo, "Pleno Contato”, e oitavo, “O Jantar”, Augusto Machado visita a casa de Gonzaga de Sá, no alto de Santa Teresa. Por fim vai conhecer a morada do mestre. R. J. Oakley define a visita como uma viagem no espaço - ao subir o morro - mas também no tempo, pois Gonzaga e Escolástica, sua tia que o criou, representam o passado no romance. Entre as recordações está a de um concerto dado pelo pianista norte-americano Gottschalk durante a Guerra do Paraguai, num teatro já demolido, o Provisório. Era outro rastro do Império que havia muito perecera. "Gonzaga marca para Machado o local onde o teatro uma vez se erguia. Como que por contágio, Machado embarca numa relação com sua cidade” escreve Oakley (2011, p. 120).

Escolástica recorda também o concerto da cantora de ópera Rosine Stoltz. "Nunca houve aqui um benefício como o dela", inicia a septuagenária. "Hoje, quando me recordo, me parece estar vendo a sala do Provisório repleta e linda de senhoras e moças"; a sala, recorda Escolástica, explodiu em um aplauso que "parecia uma palma só; todas ao mesmo tempo" (BARRETO, 2017e, p. 124).

Augusto Machado nota a emoção dos anciãos, pondera que o carioca tinha fraco pelo Lírico - nome que o Provisório, já tendo durado dois anos, assumiu em 1854 ao que Gonzaga de Sá retorque: "Influência do Império", e começa a explicar por que era tão importante o Provisório, que havia custado "rios de dinheiro". Acontece, diz ele, que era preciso um salão, "um lugar de encontro para a grande gente", que carecia de cultura e que sem ter tido "forte preparo na mocidade [...] só podia compreender a música e a ópera, no teatro, lugar em que pouco se fala”. Segundo o velho amanuense, a ideia do imperador tinha sido criar um espaço de convivência para obrigar essa gente a se encontrar e casar entre si. "Falhou. A nobreza não se fez e o Lírico degenerou em moda idiota, sempre com o mesmo espírito curto, mas sempre em roda de tolos.” (BARRETO, 2017e, p. 125) 
Lima Barreto insere, na explanação de Gonzaga sobre o teatro, não só a ideia imperial de civilização ("Era preciso uma casa elegante para poli-los com o auxílio da arte”) como também o gérmen da crítica que faria ele próprio ao Teatro Municipal, desde o começo das reformas acalentado por Pereira Passos e inaugurado em 1909 como já vimos, numa espécie de coroamento civilizatório da avenida Central.

Em 1911, na revista $A$ Estação Teatral, Lima escreve duas crônicas, intituladas "Uma coisa puxa a outra..." I e II, publicadas nos dias 8 e 22 de abril. Na primeira, comenta que andava pensando "à margem" sobre o Municipal, mas ao fim dedica o artigo a aspectos do texto dramatúrgico - advertindo que chegará a vez de falar no edifício, o que de fato faz no segundo texto, que se inicia desta maneira (BARRETO, 2004, p. 71, vol. 1):

\begin{abstract}
O Teatro Municipal! É inviável. A razão é simples: é muito grande e luxuoso. Supondo que uma peça do mais acatado dos nossos autores provoque uma enchente, repercuta sobre a opinião, haverá no Rio de Janeiro e arredores, inclusive o Méier e Petrópolis, gente suficientemente encasacada para enchê-lo dez, vinte ou trinta vezes? Decerto, não. Se ele não se encher pelo menos dez vezes, por peça, a receita dará para custear a montagem, pagar o pessoal etc.? Também não.
\end{abstract}

De que vale, indaga, “a educação artística da população em representações para plateias vazias?”. Até os atores perderiam “o passo, o gesto, o entusiasmo”. Ora, desde logo que o teatro não era para o povo, era para "o chefe de seção, o médico da higiene, o engenheiro da prefeitura, gente entre seiscentos mil-réis mensais e cento e pouco". Ora, era claro que "essa gente não tem casaca e não pode dar todo o mês uma toilette a cada filha, e também à mulher!” (BARRETO, 2004, p. 71, vol. 1).

Mais eficaz, diz ele, seria criar uma rede de pequenos teatros de bairro, a serem tocados por pequenas empresas que receberiam uma subvenção para encenar peças populares, "além de mágicas, pequenas revistas e outras trapalhadas" - não perde a oportunidade de deixar claro que não pretendia que os habitantes de Botafogo, bairro que era considerado por ele a morada clássica da elite arrivista, frequentasse a sala; o teatro a ser feito lá "era só para os criados, empregados, etc.”. "Nesse primeiro ciclo teatral, devia entrar o Circo Spinelli, o único atestado vivo do nosso espontâneo gosto pelo teatro." Num segundo passo, deveria vir um "pequeno teatro cômodo, mas sem luxo" no centro da cidade, também subvencionado, para companhias de fato 
municipais. Assim, conclui, teríamos “o ensino primário e o secundário teatral”, para só depois, "mudado o gosto pelo palco", ter enfim o "ensino superior". (BARRETO, 2004, p. 72, vol. 1).

O conceito de uma civilização cenográfica, feita de arremedos importados, é curiosamente ironizado no nono capítulo de Vida e Morte de M. J. Gonzaga de Sá.

Estando Augusto Machado sentado no Café Papagaio - onde Lima se reunia com seus amigos do "Esplendor dos Amanuenses", confraria da qual faz parte Machado no romance - vê passar do lado de fora "grandes mulheres estrangeiras, cheias de joias, com espaventosos chapéus de altas plumas, ao jeito de velas enfunadas ao vento, impelindo grandes cascos". Observando-as, recorda uma frase de Gonzaga de Sá, “a dama fácil é o eixo da vida” (BARRETO, 2017e, p. 127).

A comparação que Lima Barreto faz aqui, pela voz de Augusto Machado, entre os chapéus e as velas, ecoa aquela descrição das mulheres que impactavam Isaías Caminha em meio à multidão das ruas da cidade grande - "bonitas e feias, grandes e pequenas, de plumas e laçarotes, farfalhantes de sedas; eram como grandes e pequenas embarcações movidas por um vento brando que lhes enfunasse igualmente o velame" (BARRETO, 2017d, p. 103).

Enquanto no livro de estreia as mulheres eram o símbolo inebriante da metrópole, neste que seria seu último romance publicado em vida - mas, lembremos, concebido ao mesmo tempo que aquele - as mulheres enfeitadas aparecem como prostitutas estrangeiras que aqui havia chegado com "alguns vestidos de segunda mão e muitas malas ocas", mas com "a estranha fisionomia dos mármores que os séculos consagraram” (BARRETO, 2017e, p. 127). Augusto Machado devaneia longamente sobre o poder de sedução que essas mulheres diferentes - estranhas - exerciam, até sobre o granito, que queria que sua mica brilhasse como diamante, ou as montras que se abrem a lhes dar dinheiro ao sentirem seu perfume estrangeiro (BARRETO, 2017e, p. 127-8).

Mais adiante, volta a metáfora em fio39 das embarcações (BARRETO, 2017e, p. 128).

39 Sobre o conceito de "metaphore filée" ou "sustained metaphor", veja-se PIMENTEL, 1990, pp. 28-9. 
E elas continuam a passar muito grandes, bojudas, com cascos antigos rebocados pelos grandes chapéus de altas plumas, ao jeito de velas enfunadas ao vento. Passavam às duas, às quatro, como frotas de outros tempos, esquadras de naus, de caravelas, de galeões que vinham às Américas buscar prata de Potosí e ouro do coração do Brasil. E a civilização se faz por meios tão vários e obscuros que me pareceu que elas, como os veneráveis galeões que evocavam, traziam às praias do Brasil as grandes conquistas da atividade europeia, o resultado do difícil e lento evolver dos milênios.

Tal qual os conquistadores, a saquear o país, chegam essas mulheres estrangeiras; ao mesmo tempo, “a civilização se faz por meios tão vários e obscuros”, pondera Machado, que era de considerar o fato de que elas também traziam consigo algo. Enquanto as mulheres que faziam a multidão de Isaías Caminha, assim como as vitrines com artigos finos, gritavam "somos a civilização" de forma acachapante ao jovem recém-chegado da província, as mulheres de vida fácil de Vida e Morte de M. J. Gonzaga de Sá fazem o jovem amanuense, olhando a rua por detrás dos vidros de um café, pensar naquele conceito de civilização que guardava o Império, carreada pelo "lento evolver dos milênios".

Essas mulheres, como o vê Gonzaga de Sá, têm uma missão. "Estão se dando ao trabalho de nos polir" (BARRETO, 2017e, p. 129), diria ele a Augusto Machado, certa vez na confeitaria Colombo, para em seguida fazer uma longa enumeração de todas as formas como elas contribuíam para

afinar nossa sociedade, tirar as asperezas que tinham ficado da gente dada à chatinagem e à veniaga dos escravos soturnos que nos formaram; era trazer aos intelectuais as emoções dos traços corretos apesar de tudo, das fisionomias regulares e clássicas daquela Grécia de receita com que eles sonham. Quantas delas não inspirariam belos versos e quantas não viviam nos períodos arredondados deles!

Nas mesmas confeitarias e cafés por onde circulavam o jovem Lima e seus amigos, tramando revistas contra o coelhonetismo que cultivava Grécias voláteis como o escritor mais tarde diria em "O destino da literatura" -, Gonzaga de Sá expõe a seu colega mais moço as conveniências com o contato das civilizações estrangeiras por meio das mulheres de vida fácil.

Elas viriam para nos livrar dos defeitos resultantes da mistura de raças e ainda - seguindo a fala do velho amanuense - ensinar aos maridos o que comprar para suas 
mulheres, movimentando o comércio e "requintando o gosto e o luxo". Até que Machado retoma o início, explicitando o que já nos era dado adivinhar desde que falara em galeões e caravelas (BARRETO, 2017e, p. 129):

E a civilização se faz por tantos modos diferentes, vários e obscuros, que me parecem ver naquelas francesas, húngaras, espanholas, italianas, polacas bojudas, muito grandes, com espaventosos chapéus, ao jeito de velas enfunadas ao vento, continuadoras de algum modo da missão dos conquistadores.

É rico em leituras esse trecho em que se associam sexo e civilização; não é possível ler o que ensina Gonzaga senão pelo reverso: a civilização que os intelectuais republicanos tanto esperavam era resultado de uma invasão; como o avesso dos estupros de negras escravas pelos seus senhores brancos, as prostitutas estrangeiras, na cama, ensinam seu requinte importado aos brasileiros.

De uma cena cotidiana, que pareceria reforçar as ideias feitas sobre a vida na metrópole, Lima consegue jogar-nos novamente na questão racial, das origens suas e do país.

Quando cessa o devaneio de Augusto Machado e ele já se encontra com seus amigos do "Esplendor dos Amanuenses", chega de súbito Gonzaga de Sá, com os olhos vermelhos, a comunicar-lhe que seu compadre tinha morrido e ele precisava de Machado para carregar o caixão (BARRETO, 2017e, p. 130-2).

Viajam juntos até o subúrbio de Engenho Novo, onde vivia o compadre. Vão os dois no bonde, Augusto Machado muito perturbado pela ideia da morte, assolado por pensamentos soturnos a respeito de quão vã é a vida, quando entreouve uma conversa sobre "a grande tese das raças". Um homem diz ao outro, "com um grande anel simbólico" no indicador: "Tem a capacidade mental, intelectual, limitada; a ciência já mostrou isso" (BARRETO, 2017e, p. 134).

Acontece que Raimundo deixa o filho Aleixo Manuel, o afilhado de Gonzaga de Sá; um menino filho de pai branco e mãe negra, que já havia morrido, mestiço portanto como Augusto Machado, sobre o qual o jovem conjectura: "Coitado! Nem o estudo lhe valeria, nem os livros nem o valor, porque, quando o olhassem diriam lá para os infalíveis: aquilo lá pode saber nada! [...]” (BARRETO, 2017e, p. 147). 
Não será certamente fortuito que o capítulo se inicie com a descrição de uma agitada rua no centro da cidade e termine num subúrbio onde vive e morre gente mestiça; gente como Lima Barreto e como Clara dos Anjos. 


\section{Capítulo 3: uma vida à margem}

Em sua prática literária, Lima Barreto repetidas vezes abordou a vida suburbana, presente em contos, crônicas e romances; mas nunca em sua obra o subúrbio foi, tanto quanto em Clara dos Anjos, mais do que cenário, o tema central.

Esse romance de publicação póstuma talvez tenha sido a maior obstinação literária do escritor. Foi um projeto acalentado por Lima Barreto desde 1904, quando aparecem em seu diário as primeiras anotações dando conta da personagem Clara e de outros que, com ela, comporiam a trama.

A obra que ele manteve na gaveta durante tantos anos terminou sendo um folhetim, publicado entre 1923 e 1924, de crítica social e racial, no qual se conta a história da mulata Clara, moça de dezessete para dezoito anos, seduzida por Cassi Jones, um malandro branco, com um largo histórico de conquistas semelhantes. Ambos são moradores do subúrbio, mas em diferentes bairros.

O romance também demonstra a heterogeneidade dos bairros ao longo da Estrada de Ferro Central do Brasil, uma diferença que o genérico termo "subúrbios" não denota. No livro, vemos que há os que abrigam sua pretensa aristocracia, composta daqueles remediados, e mais claros, que reinam sobre os menos.

“É uma aristocracia curiosa”, escreve Lima Barreto em 1911, “em cuja composição entrou uma grande parte dos elementos médios da cidade inteira: funcionários de pequena categoria, chefes de oficinas, pequenos militares, médicos de fracos rendimentos, advogados sem causa, etc.” (BARRETO, 2004, p. 92, vol. 1) ${ }^{40}$.

A história de Clara dos Anjos teve três diferentes versões escritas e publicadas. A primeira, do diário, é incompleta e só foi conhecida com a edição das Obras de Lima Barreto; a terceira, em folhetim, é póstuma e foi reunida em livro também por Francisco de Assis Barbosa. Entre uma e outra, houve um conto publicado por Lima

${ }^{40} \mathrm{O}$ trecho está em "Esta minha letra...", uma crônica muito citada porque dá conta de um aspecto notório na biografia do escritor - sua terrível caligrafia. No texto, publicado pela Gazeta da Tarde a 28 de junho de 1911, está Lima no trem e observa pela janela "o aspecto desordenado dos nossos subúrbios se desenrolando" sob seus olhos, enquanto "o trem se enchia da mais fina flor da aristocracia dos subúrbios” (BARRETO, 2004, p. 92, vol. 1). 
Barreto no volume Histórias e sonhos, em 1920, que constitui praticamente um esboço para a terceira versão, que seria publicada em dez capítulos pela revista Mundo Literário, entre janeiro de 1923 e maio de 1924.

Da comparação entre a primeira e a terceira versões é possível traçar uma análise sobre como se modificou a percepção de Lima Barreto do ambiente urbano ao longo dos anos que compõem o arco de sua carreira literária.

A versão de Clara dos Anjos publicada como apêndice à edição do Diário íntimo constava, como explica a nota prévia ao diário, entre os papéis do acervo de Lima Barreto, num amarrado feito pelo próprio escritor e por ele mesmo datado como sendo de 1904, "inédito e incompleto" (BARRETO, 1961, p. 20).

Em 1904, quando pela primeira vez Lima Barreto rascunha Clara dos Anjos, o centro do Rio enfrentava aquele que já chamamos, com Giovanna Rosso Del Brenna, o "ano das demolições", com logradouros inteiros da região desaparecendo, como a sinuosa rua da Prainha, que teve um lado todo derrubado (BRENNA, 1985, pp. 136140) e que daria espaço à criação da rua do Acre. A 8 de março daquele ano, registrase nos jornais a inauguração das obras da avenida Central (BRENNA, 1985, p. 152). Em agosto, foi adquirida a última casa que fazia falta demolir para que passasse o novo eixo do centro da cidade (BRENNA, 1985, p. 210).

A questão sanitária não se dissociava da questão das obras e esta, por sua vez, implicava a da moradia dos mais pobres. Como sintetiza o cronista Carlos Laet (Jornal do Brasil, 24.ago.1904, p. 1).

$\mathrm{E}$, depois, não vale negar que o problema do saneamento foi invertido pelos poderes públicos. Nós estamos na situação de alguém que requeresse tratamento, ar puro, água à farta, e a quem se prometesse um objeto de luxo. Os primeiros cuidados deveriam ser para o útil: e que depois viesse o bonito.

Acresce que, pelas muitas demolições, já é considerável o número de pessoas que ficaram sem ter onde morar - número este que ainda se aumenta com o dos habitantes de prédios condenados e por ora não reconstruídos. Para onde vai toda essa gente? Para os subúrbios, onde se estão aglomerando, e para onde transportam os organismos saturados de germes de moléstias; para os subúrbios de onde vêm e aonde voltam nos comboios da Central, destituídos de condições higiênicas, e antes apropriados para favorecer o contágio em toda aquela gente, que ali viaja, apinhada, mormente nos trens de operários e nos de $2^{\mathrm{a}}$ classe. Ora, exatamente nos subúrbios é que mais se desenvolve a epidemia. 
Napoleão III, cujas magnificências o sr. Rodrigues Alves procura macaquear - Napoleão, rasgando boulevards, paliava a questão socialista, dando que fazer ao proletariado; e, por outra parte, mandava construir habitações baratas e salubres para os operários. Porque não se trata já disto? Uma estalagem que se fecha, não é um foco de infecção extingo, é um viveiro de epidemias que se transfere para outro ponto [...]. Não é na Grande Avenida que irão residir os expulsos dos prédios demolidos...

Lembremos que este é também o ano da Revolta da Vacina, da qual já falamos - e na qual os sublevados contra a imunização obrigatória armaram-se inclusive com materiais das obras viárias (SEVCENKO, 2013).

A situação de moradia se fazia a cada dia mais complexa após as desapropriações - mais cruéis ainda para os que não eram proprietários e se viam simplesmente no olho da rua de um dia para o outro, sem ter para onde ir, como coloca Jaime Larry Benchimol (1992, p. 249).

As desapropriações constituíram um dos mecanismos básicos acionados pelo Estado para executar os melhoramentos urbanos em proveito do grande capital comercial e financeiro e de seus "sócios menores". Atingira de maneira desigual o conjunto da população das áreas visadas.

Para os não proprietários, ou seja, para o proletariado e uma parcela das classes médias que habitavam as casas de cômodos, cortiços, estalagens e prédios deteriorados existentes no centro, elas significaram a expulsão pura e simples de seus locais de moradia.

As demolições agudizaram enormemente a escassez de alojamentos para os trabalhadores que, em sua maioria, não puderam se transferir para os bairros emergentes na Zona Norte e os subúrbios, distantes de seus locais de trabalho.

Tal era a situação da falta de moradia para os pobres que, em outubro de 1905, foi instaurada por J.J. Seabra, ministro do Interior e da Justiça, uma comissão para tratar do problema da habitação popular. Era formada por sete membros de áreas diferentes, e seu secretário era Everardo Backheuser, ex-colega de Lima Barreto na Politécnica, que se tornara engenheiro civil e era inspetor da Diretoria Municipal de Obras. A comissão constatou que o número de desalojados ficara muito além da expectativa, fosse pelas demolições, fosse pela especulação que as obras geraram. Os documentos firmados por Backheuser dão conta do problema, inclusive falando da desumanidade que era impor aos operários, que já tinham um turno pesado, longos 
deslocamentos para virem dos subúrbios para seus trabalhos, no centro - mas não serviram para resolvê-lo, como se sabe (BENCHIMOL, 1992, pp. 286-8). Quem pôde sair do centro saiu. Quem não pôde se acomodou novamente de forma precária.

Os que conseguiram ficar nos arredores da região central, de modo geral a população remanescente dos cortiços e outras habitações precárias desmanteladas, originariam a população dos favelados; destituídos de recursos, não podiam migrar para áreas mais salubres e distantes, conectadas ao centro por bondes e trens, cuja passagem não podiam pagar. É o que registra, por exemplo, Benchimol, em outro texto (1985, p. 608).

\begin{abstract}
$\mathrm{Na}$ época, os subúrbios constituíam uma alternativa de moradia prioritariamente aos que possuíam uma remuneração estável e suficiente para as despesas de transporte, aquisição de um terreno, construção ou mesmo aluguel de uma casa. A princípio, o subúrbio foi acessível a segmentos das "camadas médias", como funcionários públicos, militares, empregados ou mesmo trabalhadores especializados, ao passo que era inviável para aquela multidão que vivia do ganho e da viração, assim como para os operários, que, em sua grande maioria, recebiam "diárias" irrisórias, sem nenhuma garantia de trabalho.
\end{abstract}

Os dados disponíveis a respeito do transporte de passageiros em trens apontam uma explosão no decênio que vai de 1896 a 1906: o número de pessoas que viajam nos trilhos da Estrada de Ferro Central do Brasil quase quadruplica, passando de 5.257.683 passageiros para 19.239.236 ao ano (FERNANDES, 2015, p. 127).

É esse, pois, o cenário já da primeira versão, aquela que consta no diário, incompleta, de Clara dos Anjos. Nela, o pai de Clara era contínuo da Secretaria da Agricultura; a família era composta de pai, mãe, filha e de "uma velha preta, a Babá, que já escrava já livre, rolara até aos cinquenta e tantos anos, quando viera parar às mãos deles" (BARRETO, 1961, p. 223). Constituem um grupo exemplar dessa classe média descrita por Benchimol, que se satisfaz com a vida cotidiana. O pai, que nesta versão chama-se Manuel Antônio, vai todos os dias para o trabalho, no centro da cidade, em bonde; lê jornais, guardando para Clara o folhetim, nome dado à seção de amenidades onde também se publicavam histórias em capítulos; e passeia pelas ruas da região, conversando aqui e ali, antes de regressar ao lar por volta das quatro da tarde. A isso se resume sua rotina, e a da mulher, aqui chamada Florência, pouco variava, limitando-se à missa de vez em quando longe de casa. 
Clara, contudo, tinha uma vida menos "monótona e encarrilhada” que a dos pais. Havia estudado enquanto o pai tivera energia para prover-lhe uma boa educação num externato para moças, incluídos aí os estudos de piano, mas, à altura em que se desenrola a ação, tinha nas festas em casa do padrinho "sua forte preocupação”, sempre requerendo novos trajes para comparecer às comemorações. Esse padrinho, o senhor Carlos Alves da Silva, é importante dizer, é um funcionário mais graduado que Manuel Antônio, com o qual este travara conhecimento em 1869, "ainda amanuense" na volta da Guerra do Paraguai (BARRETO, 1961, pp. 224-5).

A casa do padrinho é, nessa primeira versão do romance, o centro da vida social de Clara. A família Alves da Silva tem mais posses e vive num subúrbio melhor que o dos Anjos, contraposição esta que representará a heterogeneidade dos subúrbios que, na terceira versão, exposta na família do vilão, Cassi Jones.

A essa primeira variante da história, que cobre escassas 62 páginas, faltam vários trechos, impossibilitando a perfeita compreensão da trama, que, no entanto, desenha-se de modo bastante diferente da versão definitiva publicada em folhetim e sugere uma obra que poderia ter dado um romance literariamente superior ao que efetivamente se publicou, com mais complexidades e menos maniqueísta.

Mais importante para nosso estudo, na comparação entre as duas versões, Clara é uma personagem dotada de muito mais agência do que a ingênua mocinha privada do contato com o mundo exterior pela mãe do folhetim - que aliás se chamará Engrácia, como o pai passará de ser o contínuo Manuel para se tornar o carteiro Joaquim.

Na variante do amarrado, recolhida ao final do Diário íntimo, o pai de Clara morre do coração aos 45 anos, o que obriga mãe e filha a trabalharem. A primeira tentativa da mãe é lavar roupa para fora, poupar a filha de expor-se ao mundo, aos desvios do bom caminho. Mas a primeira família que lhe encarrega os préstimos vive no Catete, e a passagem do Cachambi, local de sua residência, até lá consumiria o lucro. Ao procurar ajuda do compadre, recebe do doutor Gomensoro, médico que lá se encontrava de visita, o conselho de mudar-se para Laranjeiras ou Botafogo, onde havia muitas famílias ricas - note-se que esses bairros eram ainda considerados arrabaldes, à época, e não zona sul, mas já começava a estratificação social que legava aos mais pobres os territórios servidos pela linha do trem (BARRETO, 1961, pp. 257-264). 
Essa mudança de residência não se dá - embora isso, pela falta de trechos, não se explicite no esboço. A solução encontrada para a penúria familiar é empregar Clara, que vai trabalhar num ateliê de costura. Assim, muito diferentemente do que acontece com sua versão dos anos 1920, a mocinha ganha o centro da cidade. Será vigiada por um empreiteiro, figura que surge, no esboço, sem explicações, mas cuja missão, adivinha-se, é cuidar que não aconteça a Clara o que, fatalmente, irá acontecer: ser seduzida.

Seu sedutor é um adolescente que não tem nome, mas é filho de um capitão de mar e guerra - militares e o positivismo, ainda muito presentes no ambiente local quando Lima escrevia essa primeira versão, têm um grande papel nesse tratamento da trama, papel esse descartado nas versões subsequentes da obra.

Clara e o adolescente conhecem-se nos subúrbios, mas passam a encontrar-se no centro da cidade. O lugar escolhido por Lima Barreto para esses encontros é a região do largo de São Francisco, muito conhecida dele, sendo o endereço da Escola Politécnica. Clara arma artifícios para encontrar-se com o rapaz; mente à chefe do ateliê, mente à mãe. Nas versões posteriores, apenas deixará a janela aberta para que entre Cassi Jones ou Júlio Costa, na versão em conto (BARRETO, 2010, pp. 246-55). Somente sua fraqueza final, a de deixar-se acompanhar pelo rapaz ao quarto onde será deflorada e onde se encontrará com ele ainda outras vezes, é atribuída não à determinação, mas ao álcool: Clara toma com ele um copo de cerveja. "Alcoolizada, com as promessas do rapaz e sobretudo aquele seu temperamento de torrão de açúcar”, cede e se deixa levar ao ambiente vil, deteriorado, onde apenas figuras eróticas nas paredes e uma "reles cama de ferro" compõem o cenário de sua desgraça final (BARRETO, 1961, p. 275).

Nos encontros seguintes, aos quais acede por seu "temperamento ardente" (BARRETO, 1961, p. 276), Clara vai dando jeito nos aposentos, ironicamente referidos como "o chateau", tirando-lhes a mácula, por assim dizer, na esperança de um casamento com o rapaz, que, no entanto, cada vez se torna mais abrupto no trato e menos interessado nos devaneios da mocinha. Para cúmulo, facilita a entrada de outro, que tenta violar a moça, à qual chama de "sua negra" (BARRETO, 1961, p. 281), numa frase sintética das relações sociais no alvo de Lima Barreto. 
Clara se salva clamando por socorro; o invasor é preso. A notícia sai nos jornais - note-se que trazendo "o nome da rapariga por extenso e o dos rapazes pelas iniciais". Também aparecem publicadas as iniciais do militar, pai do sedutor inicial, “denunciando a filiação” (BARRETO, 1961, p. 282). Na cena final, inconclusa contudo, o pai nega peremptoriamente resolver a culpa do filho, a essa altura evidente, pela via do casamento, solução proposta pela lei da época (BARRETO, 1961, p. 283).

- Oh! Isso absolutamente não, disse ele com um imperceptível "isso". Não se compreende que a lei obrigue a se casar gentes de situações diferentes, de cores, de educação, só porque se encontraram...

- Vossa Excelência...

A literatura realista é pródiga em romances batizados com o nome de seus protagonistas. Clara dos Anjos talvez seguisse os rumos de uma Emma Bovary ou de uma Anna Kariênina na versão que Lima Barreto primeiro encetou para sua história. A heroína que ali se esboça é um pouco mais próxima daquelas mulheres, cujas decisões ativas as levam à desgraça que, de antemão, sabemos que as espera.

A versão comentada acima é a que se encontrava no amarrado encontrado por Francisco de Assis Barbosa na Limana. No entanto há diferenças mesmo entre essa versão incompleta, editada como apêndice do Diário íntimo, e as notas do diário propriamente dito, no ano de 1904.

Nas anotações, Lilia Schwarcz identifica essa proximidade com o realismo (SCHWARCZ, 2017, p. 154). No esquema nas entradas do diário, acompanha-se a vida de Clara após a defloração, prolongando-se em desventuras - tem uma filha, é abandonada, se casa, enviúva, se amiga com um pedreiro - bem ao estilo das tramas realistas com suas infelizes heroínas. Além do mais, como observa Schwarcz, sua filha lhe segue os passos da desventura, fugindo com um cabo de polícia, sendo essa repetição determinista outro tópico dos romances da corrente realista.

No esquema feito no diário, observa ainda Lilia Schwarcz, há mais comprometimento com o “"negrismo’, com a denúncia das estruturas de opressão” e também há mais esperanças quanto às "possibilidades de reação por parte dessas 
populações". "Basta notar a metáfora fácil de a defloração da protagonista acontecer bem no dia 13 de maio de 1888”, aponta a historiadora (SCHWARCZ, 2017, p. 155).

A personagem do romance publicado entre 1923 e 1924, no entanto, é bem diferente. Sua inocência, e mais que isso, sua ignorância geral das coisas do mundo a tornam um objeto da trama, mais do que em um agente a propeli-la.

Embora Clara dos Anjos seja o primeiro livro que Lima Barreto anuncia para si mesmo estar escrevendo, foi o último que consignou à publicação. Quando o faz, na versão já bastante modificada que saiu em folhetim postumamente, vinha de cinco anos de intensa tentativa de finalizar sua obra, como conta seu biógrafo, "na presciência da morte que se aproximava” (BARBOSA, 2017, p. 304).

Até 1917, publicara em livro somente Recordações do escrivão Isaías Caminha, em 1909, e Triste fim de Policarpo Quaresma, em 1915. Vendo a saúde fraquejar sob os efeitos do álcool, passa, a partir de 1917, a ordenar feericamente os papéis de sua biblioteca, organizando tanto o catálogo da Limana quanto seus inéditos.

Aposentado e vivendo em Todos os Santos, conclui, no período que vai de 1920 a 1922, cinco volumes: Histórias e sonhos, Marginália, Feiras e mafuás, Bagatelas e Clara dos Anjos. Francisco de Assis Barbosa atribui à "ânsia incontida de concluir a obra que mal havia começado” os descuidos comumente notados pela crítica nos últimos livros do escritor (BARBOSA, 2017, p. 307).

Como registra Francisco de Assis Barbosa, Lima acabaria por se afeiçoar à vida do subúrbio, passeando por suas ruas, lendo o jornal na venda do seu Ventura e conversando com seus vizinhos no botequim (BARBOSA, 2017, 268).

Esse cotidiano fornecerá a matéria prima para a versão final de Clara dos Anjos. O dia a dia suburbano é tema também de várias crônicas, muitas escritas em paralelo à redação final do romance, comprovando quão atento estava Lima Barreto à observação do mundo ao seu redor. Esses textos na imprensa oferecem oportunos complementos ou contrapontos ao que o escritor apresenta em Clara dos Anjos.

Em carta a Almáquio Cirne, em 5 de janeiro de 1921, conta ter terminado o romance, para ser publicado em capítulos, por encomenda feita no ano anterior pela 
diretoria da Revista Souza Cruz (apud BARBOSA, 2017, p. 312n) ${ }^{41}$. Assim, pode-se deduzir que, premido tanto pela necessidade de deixar concluídas suas obras quanto pela necessidade de renda, resolve estender aquele conto, que saíra em Histórias e sonhos (1920), último livro publicado com o escritor em vida.

Não sabemos quando, no lapso entre a encomenda e a edição de Histórias $e$ sonhos - cuja nota prévia é assinada pelo autor a 8 de dezembro de 1920 - Lima Barreto optou por Clara dos Anjos para atender à revista42. Talvez tenha sido uma opção tomada desde um primeiro momento, para preencher assim sua ambição de ver o antigo projeto editado. Pela datação ao final do livro, sabemos que a transformação daquela narrativa breve, já muito diferente do esboço de 1904, em folhetim, ocorreu entre dezembro de 1921 e janeiro de 1922.

A pressa, contudo, não significa improviso. Lima Barreto não simplesmente fatiou sua ideia original, mas a reescreveu pensando no formato capitulado, o que fica patente pelos fechos que dá a cada episódio, como bem observa Beatriz Resende (2012, p. 15). A forma resultante nesta versão final é também ela um elemento de análise para nós. Em que medida a capitulação reflete o isolamento dos subúrbios?

Ao fazer a adaptação do conto para série capitulada, Lima escreve já não a história de uma jovem seduzida e abandonada, tópico caro ao gênero folhetinesco, em especial naquela que Marlyse Meyer identifica como sua terceira fase, a de origem naturalista, que aborda os "dramas da vida" e os "faits divers" (MEYER, 2005, p. 233), mas um romance que tem como verdadeiro protagonista os subúrbios.

Assim, a trama que seria principal dentro das convenções do gênero em que se insere - a da mocinha seduzida e abandonada - é, em certa medida, um estratagema, uma forma de manter o leitor preso, na espera do que acontecerá, enquanto o que de fato acontece é o retrato, em quadros quase independentes, de aspectos vários da vida suburbana, tal como o autor a via.

\footnotetext{
${ }^{41}$ BARRETO, Lima. Correspondência ativa e passiva. São Paulo: Brasiliense, 1956, p. 203, vol. II.

42 Tampouco sabemos por que a narrativa acaba publicada, sempre em capítulos, pela revista Mundo Literário, menos sofisticada do que a publicação patrocinada pela fábrica de cigarros, mas importante no meio da literatura, como aponta Beatriz Resende (2012, pp. 10-1).
} 
Em Clara dos Anjos, pouco tempo é empregado na efetiva sedução da personagem-título - que, como observamos mais acima, já não é tanto sujeito da ação, mas objeto da trama. O livro se dedica a uma detalhada descrição do modo de vida, valores e locais suburbanos e aos malfeitos de Cassi Jones, o vilão que ludibria Clara, e seu bando, ficando quase que somente o ato final para a sedução.

Clara, cumprindo o corolário do gênero (MEYER, 2005, p. 245), de fato engravida. Porém ela não é nem mesmo a única mãe forjada pela sedução desse Don Juan do Méier. Há, antes a que caiu na vida e vive na Misericórdia, não por acaso região degradada do centro da cidade após as remodelações propostas por Pereira Passos e continuadas por Carlos Sampaio. Esta aparece no único momento, ao fim do nono e penúltimo capítulo, em que a região central é pano de fundo da ação, quando Cassi Jones, numa excursão desastrada, tenta viabilizar sua fuga após ter comandado o assassinato do padrinho de Clara.

É importante dizer que, nesta versão, o padrinho, Marramaque, é um funcionário rebaixado por invalidez a contínuo, portanto bem menos graduado que o Alves da Silva do esboço de 1904. Trata-se de um homem que se ilustrara pelo convívio do poder, com inclinações para a política e que tenta, desde o início, manter a afilhada afastada do violeiro que terminaria por seduzi-la.

Se o centro é retratado de esguelha no livro, somente como um cenário associado à sordidez no capítulo IX, o subúrbio aparece ao longo de todo ele.

O local de residência da família Dos Anjos - Joaquim, Engrácia e Clara - não é especificado. Sabemos, no entanto, pela descrição inicial do espaço no capítulo primeiro do livro, que a rua onde vivem é caminho para a freguesia de Inhaúma, como era o Cachambi, morada da personagem-título na versão de 1904 (BARRETO, 2012, p. 65).

A rua em que estava situada a sua casa desenvolvia-se no plano e, quando chovia, encharcava e ficava que nem um pântano; entretanto, era povoada e se fazia caminho obrigado das margens da Central para a longínqua e habitada freguesia de Inhaúma. Carroções, carros, autocaminhões que, quase diariamente, andam por aquelas bandas a suprir os retalhistas de gêneros que os atacadistas lhes fornecem, percorriam-na do começo ao fim, indicando que tal via pública devia merecer mais atenção da edilidade. 
A transformação dos subúrbios de arrabaldes aprazíveis em locais aos quais a edilidade destina pouca atenção é uma realidade que se torna flagrante após a modernização do centro do Rio de Janeiro; o privilégio do progresso passa a ser dado aos bairros que se desenvolviam distantes da ferrovia e que, na origem tão suburbanos quanto aqueles mais ao norte, passam a ser chamados de zona sul. O próprio Lima Barreto apontaria isso em crônicas - por exemplo, "O prefeito e o povo”, publicada na revista Careta a 15 de janeiro de 1921. O escritor não poupa Carlos Sampaio: começa desancando o político, dizendo que "é um grande prefeito, não há dúvida alguma; mas de uma cidade da Zambézia ou da Cochinchina”. Na visão do autor, “a principal preocupação" de Sampaio é dividir o Rio "em duas cidades: uma será a europeia e a outra, a indígena” (BARRETO, 2004, p. 294, vol. 2).

Todo o dia, pela manhã, quando vou dar o meu passeio filosófico e higiênico, pelos arredores da minha casa suburbana, tropeço nos caldeirões 43 da rua principal da localidade de minha residência, rua essa que foi calçada há bem cinquenta anos, a pedregulhos respeitáveis.

Lembro-me dos silhares dos caminhos romanos e do asfalto com que a Prefeitura Municipal está cobrindo os areais desertos de Copacabana.

Mas Lima sabe que essa cidade partida à força é uma só; enquanto o prefeito concentra esforços para que o povo se eduque "nas coisas de luxo e gozo", querendo "catitas" a cidade e seus habitantes, o escritor adverte: "a polícia é que vai ter mais trabalho" (BARRETO, 2004, p. 295, vol. 2).

\footnotetext{
Não havendo dinheiro em todas as algibeiras, os furtos, os roubos, as fraudes de toda a natureza hão de se multiplica; e, só assim, uma grande parte dos cariocas terá 'gimbo' para custear os esmartismos sampaínos.
}

Havia também, nas colocações de Lima Barreto sobre a preferência do prefeito por olhar para os lados ao sul da cidade a compreensão de uma discriminação que se

43 “Caldeirão", neste contexto, segundo o dicionário Aulete, pode designar um buraco; uma cova aberta para enxugar caminhos alagados; ou uma escavação feita por águas pluviais ou pela passagem de animais. Qualquer das acepções denota a falta de manutenção que Lima denuncia. 
plasmaria também no léxico. Ao sul, eram arrabaldes; ao norte, ao longo da Estrada de Ferro Central do Brasil, ficavam os subúrbios.

Sobre a relação entre a modernização da região central e a consequente deformação pela qual passa o conceito de subúrbio, Nelson da Nóbrega Fernandes escreveu sua dissertação de mestrado em geografia, depois convertida em livro. $\mathrm{Na}$ obra, O rapto ideológico da categoria subúrbio, o geógrafo situa Lima Barreto como um dos primeiros a acusarem "o deslocamento do significado tradicional da palavra subúrbio entre nós”, citando uma crônica publicada pelo escritor na Revista Suburbana, em 3 de setembro de 1922. Neste que é, portanto, um de seus últimos escritos, Lima Barreto fará uma descrição do triste estado da região na qual viveu toda a vida.

"Morando nos subúrbios, e até num único há cerca de vinte anos, tenho notado que a maioria dos seus moradores está sempre a esperar da municipalidade e do governo federal os melhoramentos de que essa parte da cidade carece", escreve o cronista na abertura do texto, que se chama "Meditem a respeito". (BARRETO, 2016, p. 338). Nele, Lima Barreto propõe que a iniciativa privada se encarregue de embelezar os subúrbios, já que o governo não o faz, como uma espécie de compensação pelo que da região os particulares tiraram. De quebra, com algum cinismo, o escritor aponta que, vindo os ricos, viria o dinheiro público.

Embora longo, vale a pena citar quase integralmente o trecho final, no qual o escritor descreve as mazelas da região que tão bem conhece, após décadas de falta de ordenamento público para seu desenvolvimento. Nesse fragmento, o autor faz uma espécie de contraposição entre o que a seu ver deveria ser o subúrbio, uma espécie de cidade-jardim bem-cuidada, e o que de fato ele se torna, pelo abandono, um rebotalho urbano, com as mazelas da cidade e sem suas benesses (BARRETO, 2016, pp. 339340).

A construção nos subúrbios se ressente de uma lamentável fealdade e de uma total incongruência com o local. As casas não são construídas com o aspecto de graciosas casas de subúrbios, garridas e louçãs. São hediondos, soturnos e pesadíssimos monstrengos, sem caráter próprio e relação com o local; verdadeiros paralelepípedos de alvenaria, com um puxadito ao fundo e uma varanda ao lado, compoteiras na cimalha e um horrendo porão com mezaninos, tendo grades de cadeia. Quando não são desse tipo, são os velhos chalés, que 
hoje estão fora de moda, e foram substituídos pelos tais paralelepípedos de alvenaria de tijolo, em cuja fachada se ostenta uma baie de vila europeia.

Ora, a iniciativa particular já podia, sem consultar nem pedir auxílio aos governos, procurar um tipo de construção que fosse adequado aos nossos subúrbios; isto dar-lhes ia mais graça, mais atrativo, e havia de torná-los lugar de passeios atraentes de gente poderosa e vagabunda, o que obrigaria a municipalidade a cuidar mais dele. A Estrada Real, hoje avenida Suburbana44, está quase toda por edificar e era bom que, por toda a extensão dela, os ricaços semeassem, de um lado e de outro, cottages graciosas, engrinaldadas em jasmineiros.

Os particulares que dispõem de posses deviam ter jardins floridos e amplos, o que modificaria o insólito aspecto urbano que atualmente têm os nossos subúrbios - coisa que não se espera topar em paragens de tal nome.

De resto, os particulares, não lhes dando nada em troca, contribuem fortemente para tirar $\mathrm{o}$ aspecto gracioso de bosque, a atmosfera de natureza, $\mathrm{o}$ verdor de selva que os subúrbios deviam possuir e lembrar. Não plantam, mas devastam as velhas chácaras que lá existiam. Anosas mangueiras são derrubadas, não se sabe por que razão [...].

Se não me falha a memória, era Dom Casmurro, de Machado de Assis, que estava escrevendo a História dos subúrbios. Creio mesmo que ele morava no Engenho Novo, numa chácara. No tempo dele, esse subúrbio devia estar crivado delas, trescalantes do aroma próprio ao arredor, e cheias de sombra e doçura amiga. Hoje... passem lá e vejam o que há. Meditem a respeito...

Eis o subúrbio abandonado de Clara dos Anjos, bastante diferente daquele, de lares respeitáveis, em que o Ricardo Coração dos Outros de Triste fim de Policarpo Quaresma ia tocar seu violão, a animar as festas das "melhores famílias do Méier, Piedade e Riachuelo" (BARRETO, 2011, p. 89). Um território feito de retalhos malajambrados, juntados uns com os outros pela conveniência e pelas possibilidades do acaso, entremeados de pedaços de natureza e tecidos rurais ainda restantes.

A casa de Clara, como já vimos, se dá numa via mal cuidada, mas que ainda assim tem importância. Já no capítulo VII do livro, o escritor fará uma descrição muito vívida do subúrbio em seus rincões mais desolados. Como tantas outras descrições das coisas construídas pelo homem que povoam a obra de Lima Barreto, esta provê páginas das mais belas deste livro. De novo, vale citar extensamente o início desse capítulo (BARRETO, 2012, pp. 182-5), no qual o subúrbio será apresentado não como o local onde seus habitantes levam uma vida pequena, mas satisfatória, qual a família de Clara

44 Atualmente av. Dom Hélder Câmara, era antes da av. Brasil o principal acesso rodoviário ao Rio. 
retratada no diário em 1904 - e sim como o "refúgio dos infelizes" (BARRETO, 2012, p. 188).

O subúrbio propriamente dito é uma longa faixa de terra que se alonga, desde o Rocha ou São Francisco Xavier, até Sapopemba, tendo para eixo a linha férrea da Central.

Para os lados, não se aprofunda muito, sobretudo quando encontra colinas e montanhas que tenham a sua expansão; mas, assim mesmo, o subúrbio continua invadindo, com as suas azinhagas e trilhos, charnecas e morrotes. Passa-se por um lugar que supomos deserto, e olhamos, por acaso, o fundo de uma grota, donde brotam ainda árvores de capoeira, lá damos com um casebre tosco, que, para ser alcançado, torna-se preciso descer uma ladeirota quase a prumo; andamos mais e levantamos o olhar para um canto do horizonte e lá vemos, em cima de uma elevação, um ou mais barracões, para os quais não topamos logo da primeira vista com a ladeira de acesso.

Há casas, casinhas, casebres, barracões, choças, por toda a parte onde se possa fincar quatro estacas de pau e uni-las por paredes duvidosas. Todo o material para essas construções serve: são latas de fósforos distendidas, telhas velhas, folhas de zinco, e, para as nervuras das paredes de taipa, o bambu, que não é barato.

Há verdadeiros aldeamentos dessas barracas, nas coroas dos morros, que as árvores e os bambuais escondem aos olhos dos transeuntes. Nelas, há quase sempre uma bica para todos os habitantes e nenhuma espécie de esgoto. Toda essa população, pobríssima, vive sob a ameaça constante da varíola e, quando ela dá para aquelas bandas, é um verdadeiro flagelo.

Afastando-nos do eixo da zona suburbana, logo o aspecto das ruas muda. Não há mais gradis de ferros, nem casas com tendências: há o barracão, a choça e uma ou outra casa que tal. Tudo isto muito espaçado e separado; entretanto, encontram-se, por vezes, "correntes" de pequenas casas, de duas janelas e porta ao centro, formando o que chamamos "avenida".

As ruas distantes da linha da Central vivem cheias de tabuleiros de grama e de capim, que são aproveitados pelas famílias para coradouro. De manhã até à noite, ficam povoadas de toda a espécie de pequenos animais domésticos: galinhas, patos, marrecos, cabritos, carneiros e porcos, sem esquecer os cães, que, com todos aqueles fraternizam. [...]

Por esse intrincado labirinto de ruas e bibocas é que vive uma grande parte da população da cidade, a cuja existência o governo fecha os olhos, embora lhe cobre atrozes impostos, empregados em obras inúteis e suntuárias noutros pontos do Rio de Janeiro.

A descrição, que abre o capítulo, ainda prossegue por algumas páginas, quase como se se tratasse de um ensaio, antes que sejamos lembrados da trama do romance em si. Passando ainda pelas agruras sofridas pelo povo do subúrbio até na morte - a dificuldade para chegar até o cemitério de Inhaúma, como já vimos, é um tema recorrente em vários escritos do autor -, chega, como não podia deixar de ser, a uma 
estação de trem. É a do Méier, onde deparamos com Cassi Jones. Ele, com sua família supostamente ligada a um aristocrata inglês, de onde tirou o falso sobrenome, habita esse bairro que é, dos suburbanos, o mais desenvolvido, com comércio e com cinemas, aos quais de vez em quando até Clara ia para algum lazer.

Lilia Schwarcz descreve algumas diferenças entre os subúrbios, nome dado às áreas residenciais e industriais fora do centro, de um modo geral, "entre a serra do Engenho Novo, o morro do Telégrafo (na Mangueira) e o morro do Retiro (em Realengo)”, um “território longilíneo" que segue os trilhos da Central (2017, p. 167).

Paralelamente, foi se instituindo uma clara hierarquia interna, na qual alguns bairros eram considerados menos providos de infraestrutura - como Cascadura - e outros definidos localmente como mais chiques e elegantes. Esse foi o caso de Boca do Mato - conhecido em virtude de seu clima serrano como Suíça Suburbana ou Europa dos Pobres -, Jacarepaguá, Tijuca e, em certo sentido, do amplo distrito do Méier. Os bairros menos equipados eram, não por acaso, os mais distantes do centro e aqueles ocupados basicamente por uma população pobre e imigrante, que sai do Rio com a Reforma Passos e com o fim da escravidão. Já as vizinhanças mais "aristocráticas" - segundo os termos da época - foram habitadas pelas elites que optaram por viver mais afastadas da "cidade grande" - em chácaras e propriedades ajardinadas - e por um vasto funcionalismo público, resultado da grande oferta de empregos administrativos providos pela capital do país.

Todos os Santos, onde vivia Lima Barreto, é hoje atendido pela estação de trem do Engenho de Dentro ou pela do Méier - naquela época, contudo, tinha sua própria parada. "Os habitantes de Todos os Santos julgam a sua estação excelente por ser pacata e sossegada, mas os do Méier acusam os de Todos os Santos de irem para o seu bairro tirar-lhe o sossego", escreveu Lima na Careta de 11 de dezembro de 1915, numa crônica intitulada "Os outros" (BARRETO, 2004, p. 253, vol. 1). Isso porque - como também registrou o escritor, na crônica "A estação”, publicada na Gazeta de Notícias, a 6 de outubro de 1921- o Méier era o "orgulho dos subúrbios e dos suburbanos" (BARRETO, 2004, p. 439, vol. 2).

Tem confeitarias decentes, botequins frequentados; tem padarias que fabricam pães, estimados e procurados; tem dois cinemas, um dos quais funciona em casa edificada adrede; tem um circo-teatro, tosco, mas tem; tem casas de jogo patenteadas e garantidas pela virtude, nunca posta em dúvida, do Estado, e tem boêmios, um tanto de segunda mão; e outras perfeições urbanas, quer honestas, quer desonestas. 
Cassi Jones, pois, habitava o Méier, “o orgulho dos subúrbios”. Ali na estação, pensando que nunca na vida havia trabalhado, em seus quase 30 anos, considera como vai voltar a se aproximar da filha do carteiro.

Está imerso em seus devaneios quando providencialmente encontra a figura de Praxedes, um rábula negro, um pouco corcunda, descrito no capítulo IV, o da festa dos anos de Clara, à qual Cassi tinha comparecido, acertando o coração da mocinha com seus dotes musicais. Frequentadores ocasionais da casa do carteiro, sem outro tema que os una, põem-se então a falar da família e, mais providencialmente ainda, surge no diálogo a figura do pobre Meneses, um dentista autônomo que, por estar encarregado de cuidar de dores dos dentes de Clara, torna-se o emissário perfeito para a artimanha que Cassi tem em mente.

A figura de José Castanho de Meneses merece atenção pelo papel que terá na trama. Ele é, de todos os personagens de Clara dos Anjos, o mais infeliz dos infelizes refugiados no subúrbio, aqueles que "perderam o emprego, as fortunas; os que faliram nos negócios, enfim, todos os que perderam a sua situação normal” (BARRETO, 2012, p. 188).

Nessa enumeração se encaixa o filho de portugueses que se faz chamar, como o rábula Praxedes, de doutor - mas que não teve sucesso em suas tentativas de merecer o título, as quais, entre outras, incluíram um período trabalhando nas obras "da construção da avenida” (BARRETO, 2012, p. 199), propiciando-lhe uma formação autodidata em engenharia mecânica. Desencantado com seus maus sucessos, cai no álcool. Sobrevive de seus ferros dentais, num dos ofícios aprendidos vida afora, compartilhando uma casa mínima e miserável com a irmã e um sobrinho apalermado. Não parece casual que um personagem tão representativo da decadência suburbana contribua, fazendo por dinheiro o papel de leva-e-traz, para o ato torpe do vilão contra a mocinha.

Na definição de R. J. Oakley, "Meneses é trágico porque nele se materializam uma série de peripécias trágicas”. Cassi Jones encontrou no tira-dentes "um pequeno elo frouxo na cadeia de solidariedade humana" dos que se haviam unido para proteger Clara, percebendo as intenções do antagonista. Cassi não é capaz de modificar “a hostilidade do pai de Clara, a integridade artística do poeta Leonardo Flores, a coragem moral de Marramaque”, mas dobra Meneses por seu bovarismo, argumenta Oakley. “A 
ambição de Meneses em ser engenheiro é um sonho no qual não há lugar para a esperança; mas, no meio da sordidez em que vive, ele mantém, zelosamente, seu arquivo e sua biblioteca sobre o tema” (OAKLEY, 2011, p. 19). Seguindo a tese de Gaultier, que Lima, como vimos, estudara, Oakley argumenta que Meneses cai na teia de Cassi Jones porque, entre os sintomas do bovarismo estão "uma profunda insinceridade e uma falta de engajamento", e que, mesmo sendo Meneses "bom”, nunca terá realmente "sucesso no caminho que escolheu na vida e sempre lhe faltará a coragem suficiente para tomar consciência do fracasso e arcar com as consequências" (OAKLEY, 2011, pp. 19-20).

\subsection{A linha do folhetim}

O escritor nos fala também da cidade ao compor personagens como Meneses, apresentados de maneira individual conforme sua presença na trama seja requerida. Capítulo a capítulo, os subúrbios de Lima vão se desenhando, numa sucessão, quase como se fossem as estações do folhetim.

Entre as figuras da trama, há também a turma de Cassi, de malandros de todo tipo; ao vilão e seu grupo é dedicado o segundo capítulo. Já no terceiro, o foco é Marramaque, o funcionário que apadrinha Clara.

A compartimentação da narrativa introduz aos bocados, além dos personagens, os hábitos e costumes suburbanos. No quarto capítulo, tem lugar a já mencionada festa de aniversário da moça, que põe em marcha a trama central. Nesse episódio, Lima Barreto descreve o ambiente de uma comemoração suburbana, com direito a comentários sobre a indumentária da menina e de convidados. O escritor não economiza nas tintas, traçando um retrato dos habitantes do subúrbio presentes.

Havia, por exemplo, dona Margarida Weber Pestana, imigrante russa que se destacava "pelo seu ar varonil” e "temperamento de heroína doméstica”, cujo pai, alemão, trabalhara como "estucador, marmorista, um pouco escultor; enfim, um operário fino" nas obras da igreja da Candelária; e havia dona Laurentina Jácome, "uma velha, sempre metida com rezas e padres, pensionista do ex-Imperador" e 
empregada numa capelinha da vizinhança”, cuidando da limpeza e das toalhas do altar (BARRETO, 2012, pp. 127-9).

“Cavalheiro digno de nota” era Praxedes Maria dos Santos, o já mencionado pretenso doutor Praxedes, um "preto baixo um tanto corcunda, com o ombro direito levantado", com um "perfil monstruoso". Deste, o narrador diz que "a monstruosidade de sua cabeça o pusera a perder". "Por tê-la assim, julgou-se uma inteligência, um grande advogado, e pôs a frequentar cartórios, servindo de testemunha, quando preciso, indo comprar estampilhas, etc. etc.”, com o que, passado certo tempo, passou a atuar como rábula. Vestia sempre fraque, botinas e levava uma pasta do tipo que estivesse na moda. "Era este o cavalheiro mais notável que havia vindo ao baile de anos de Clara” - a frase não esconde a ironia com que o escritor descreve o público de uma festa suburbana. Da aniversariante, diz que "estava bem vestidinha"; sua amiga Etelvina, porém, "uma crioulinha espevitada"45, exibia no trajar "um mau gosto de aborrecer" (BARRETO, 2012, pp. 130-1).

As festas do subúrbio como essa são tema de uma crônica deliciosa de Lima Barreto, na qual ele é bastante mais benevolente. Extensa, "Bailes e divertimentos suburbanos”, publicada na Gazeta de Notícias de 7 de fevereiro de 1922, evidencia em seus detalhes o prazer e o cuidado com que o escritor observa o ambiente. Comenta os ritmos e as modas de dança com os irmãos no café da manhã após uma festa na vizinhança e dali passa a recordar como esses bailes eram "há vinte anos passados" (BARRETO, 2004, pp. 499-500, vol. 2).

O baile, não sei se é, era ou foi, uma instituição nacional, mas tenho certeza de que era profundamente carioca, especialmente suburbano.

Na escolha da casa, presidia sempre a capacidade da sala de visitas para a comemoração coreográfica das datas festivas da família. Os construtores das casas já sabiam disso e sacrificavam o resto da habitação à sala nobre. Houve quem dissesse que nós fazíamos casa, ou as tínhamos para os outros, porque a melhor peça dela era destinada a estranhos.

45 Os termos que Lima Barreto utiliza para designar os diferentes tons de pele em Clara dos Anjos são tema de um capítulo em Lima Barreto: triste visionário. Se parecem por vezes chocantes à nossa sensibilidade, caso desse "crioulinha", esses tons, como deixa evidente Schwarcz, conformam uma paleta de lugares sociais e não dizem respeito a uma discriminação oposta a seus semelhantes pelo escritor; antes, denotam sua atenção às gradações de preconceito vigentes na sociedade (SCHWARCZ, 2017, pp. 402-29). 
Hoje, porém, as casas minguam em geral, e especialmente, na capacidade dos seus aposentos e cômodos. Nas salas de visitas das atuais mal cabem o piano e uma meia mobília, adquirida a prestações. Meia dúzia de pessoas, numa delas, estão ameaçadas de morrer asfixiadas com as janelas abertas. [...] Isto acontece com as famílias remediadas; com as verdadeiramente pobres, a coisa piora. Ou moram em cômodos ou em casitas de avenidas ${ }^{46}$, que são um pouco mais amplas do que a gaiola dos passarinhos.

Não à toa, na frase que abre o capítulo IV, lê-se: "Veio o dia da festa; a pequena casa regurgitava” (BARRETO, 2012, p. 127).

O quinto capítulo fará a contraparte do anterior. Se naquele o tema fora a diversão, neste ficará descrita, em oposição, a rotina restrita de Clara, mais ainda após sua mãe, Engrácia, abrir os olhos para o perigo representado pelo violeiro Cassi, que aparecera para cantar na festa.

As parcas andanças de Clara pelo seu bairro servem de motivo para descrever o ambiente dos arredores, com destaque para a venda de seu Nascimento, ponto de encontro dos moradores da região e também local de debate de ideias - algo assim como a venda do seu Ventura que Lima frequentava em Todos os Santos.

Faz parte desse ambiente o poeta Leonardo Flores, personagem com frequência assimilado a Lima Barreto, por ser ele um artista de cuja fama os vizinhos têm notícia, mas que, como comentam, se perdeu na bebida. Ali comparece ainda Alípio, que também tinha "amor à cachaça" e que, "sem ser instruído, não era ignorante" (BARRETO, 2012, p. 153).

Em certa medida, Alípio introduz-se como um fragmento do que uma figura como Lima Barreto poderia representar nos ambientes que frequentava nas cercanias onde vivia. É sempre Alípio quem trará as notícias lidas nos jornais - na narrativa, aliás, são frequentes as alusões à imprensa como meio de romper o isolamento suburbano e a subsequente ignorância com relação à realidade fora desse mundo

\footnotetext{
46 "Avenidas", aqui, significam um tipo de vila destinada à população de baixa renda. Assim foi definida por Everardo Backheuser em artigo para a revista Renascença, em março de 1905: “A 'avenida' é afinal uma estalagem aperfeiçoada. Uma rua central, calçada e com passeios, fica ladeada por casinhas. Essas casinhas, porém, são perfeitamente separadas, com a sua instalação de cozinha, banheiros e latrinas independentes, bem ladrilhados esses equipamentos, como mandam os regulamentos para as mais ricas residências". O título, "Onde moram os pobres", dá uma ideia de quão separada era a realidade dos leitores da revista e dos abordados na reportagem, ilustrada com generosas fotografias das diversas categorias de moradia precária existentes na cidade.
} 
compartimentado. Nele, tudo girava em torno das gares de trem da Central compartimentação essa que o escritor, mais ou menos pela mesma época, assinalaria na já citada crônica “A estação” (BARRETO, 2004, pp. 439-46, vol. 2).

O sexto capítulo apresenta a situação familiar de Cassi, rejeitado por seu próprio pai devido a seus muitos malfeitos, vivendo num porão que pode bem ser aquele "horrendo porão com mezaninos, tendo grades de cadeia" que Lima descreve na crônica para a Revista Suburbana em 1922 (BARRETO, 2016, p. 339). O vilão vive no Méier, mas numa espécie de inframundo.

Ainda nesse episódio, também se delineiam os planos do violeiro para se reaproximar de Clara, já blindada pelos cuidados da mãe.

O sétimo, como já foi dito, é o ensaio de Lima Barreto sobre o ambiente do subúrbio, em sua geografia e descuido. Nele também se descrevem a situação de Meneses e sua relação com outro bêbado e desditado suburbano, Leonardo Flores, cuja casa se apresenta muito mais bem posta que a de Meneses, mas ainda assim diminuída pelos infortúnios.

O oitavo capítulo apresentará Joaquim dos Anjos. Partindo da visão que o carteiro tem da filha, fundem-se a esta as considerações do narrador sobre a moça, "uma natureza amorfa, pastosa, que precisava mãos fortes que modelassem e fixassem" (BARRETO, 2012, p. 219). Dessas considerações, passa às que tece Clara a respeito do pai, de Cassi e da vida de maneira geral. Por fim, nesse sobrevoo, a narrativa pousa nas preocupações de Engrácia sobre a filha. É o capítulo de maior construção psicológica do livro, e culmina com a morte de Marramaque, eliminando-se assim o entrave último à sedução de Clara por Cassi Jones.

O nono e penúltimo capítulo, como já também referido, leva o leitor para um breve passeio pelo centro da cidade, acompanhando Cassi Jones. O malandro vende seus galos de briga, de cujas rinhas tirava sustento, e vai à cidade para tentar colocar o dinheiro na Caixa Econômica Federal, para armar a fuga anunciada. O episódio é primoroso no retrato que faz do desajuste desse suburbano que, em seu ambiente, faz suspirar as mocinhas, mas, fora dele, se sente diminuído. É um resumo do jogo de espelhos que Lima Barreto via entre as modas importadas de fora pela gente do centro, por sua vez repetidas de forma tosca pelos habitantes do subúrbio. 
Mais uma vez, um texto para a imprensa ilumina como Lima via seu mundo e o transportava para a ficção, retrabalhando o material da realidade. $\mathrm{Em}$ "O trem de subúrbios”, publicada na Gazeta de Notícias a 21 de dezembro de 1921, o escritor fala do ambiente da segunda classe de um trem da Central. Recordando os desenhos de Honoré Daumier - famoso caricaturista do século XIX francês, que retratara, entre outras cenas da metrópole, os passageiros de trens pendulares -, compara a tristeza resignada dos miseráveis de lá ao ambiente que circundava os que viajavam à sua volta entre os subúrbios e o centro do Rio (BARRETO, 2004, p. 467, vol. 2).

\begin{abstract}
A segunda classe dos nossos vagões de trens de subúrbios não é assim tão homogênea. Falta-nos, para sentir a amargura do destino, profundeza de sentimentos. Um soldado de polícia que nela viaja não se sente diminuído na sua vida; ao contrário: julga-se grande coisa, por ser polícia; um guarda-civil é uma coisa importante; um servente de secretaria vê Sua Excelência todos os dias e, por isso, está satisfeito; e todos eles, embora humildes, encontram na sua estreiteza de inteligência e fraqueza de sentir motivos para não se julgarem de todo infelizes e sofredores. Só alguns e, em geral, operários é que esmaltam no rosto angústia e desânimo.
\end{abstract}

Cassi Jones se arruma, se enfatiota, mas, no caminho, para o centro, sente-se tenso. Em seus pensamentos vai se formando o desprezo por aqueles "elegantes que se postavam nas esquinas e nas calçadas” (BARRETO, 2012, p. 254), desprezo que deságua na real razão de seu mal-estar, como veremos (BARRETO, 2012, 256-7).

\begin{abstract}
$\mathrm{Na}$ "cidade", como se diz, ele percebia toda a sua inferioridade de inteligência, de educação; a sua rusticidade, diante daqueles rapazes a conversar sobre coisas que ele não entendia e a trocar pilhérias; em face da sofreguidão com que liam os placards dos jornais, tratando de assuntos cuja importância ele não avaliava, Cassi vexava-se de não suportar a leitura; comparando o desembaraço com que os fregueses pediam bebidas variadas e esquisitas, lembrava-se que nem mesmo o nome delas sabia pronunciar; olhando aquelas senhoras e moças que lhe pareciam rainhas e princesas, tal e qual o bárbaro que viu, no Senado de Roma, só reis, sentia-se humilde; enfim, todo aquele conjunto de coisas finas, de atitudes apuradas, de hábitos de polidez e urbanidade, de franqueza no gastar, reduziam-lhe a personalidade de medíocre suburbano, de vagabundo doméstico, a quase coisa alguma.
\end{abstract}

Na crônica, Lima Barreto relata que, no início de sua vida pendular, vinte anos antes, incomodava-se de ver que olhassem com arrogância e desdém suas roupas “desfiadas e verdoengas", mas que já não dava importância àqueles "burocratas 
faustosos, esses escrivães, esses doutores de secretaria”. Com o tempo aprendera que "é no trem que se observa melhor a importância dessa gente toda. Eles estão na sua atmosfera própria que os realça desmedidamente. Chegam na Rua do Ouvidor, e desaparecem" (BARRETO, 2004, p. 468, vol. 2). Exatamente como seu personagem.

O capítulo culmina no encontro de Cassi com as provas vivas de seu passado. Após constatar que não seria simples depositar o dinheiro e dele dispor quando lhe aprouvesse, meio aturdido, o malandro perambula pelo bairro da Misericórdia, um dos mais antigos da cidade, no entorno do morro do Castelo. Tentando alcançar o largo de São Francisco - lembrando que este era o cenário dos encontros de Clara com o adolescente na primeira versão do romance, a de 1904 -, Cassi Jones se perde por essa região que, no texto, se configura como um resto dos melhoramentos do centro da cidade, "uma estranha cidade à parte" (BARRETO, 2012, pp. 260-1).

\footnotetext{
Penetrou naquela vetusta parte da cidade, hoje povoada de lôbregas hospedarias, mas que já passou por sua época de relativo realce e brilho. Os botequins e tascas estavam povoados do que há de mais sórdido na nossa população. Aqueles becos escuros, guarnecidos, de um e outro lado, por altos sobrados, de cujas janelas pendiam peças de roupa a enxugar, mal varridos, pouco transitados, formavam uma estranha cidade à parte, onde se iam refugiar homens e mulheres que haviam caído na mais baixa degradação e jaziam no último degrau da sociedade.
}

Ali, onde homens e mulheres escondiam "sua infinita infelicidade de deserdados de tudo deste mundo" (BARRETO, 2012, p. 261), Cassi ouve chamarem seu nome. É Inês, sua primeira vítima, que se autodefine como "aquela crioulinha que sua mãe criou” (BARRETO, 2012, p. 262). Homens e mulheres se juntam em torno daquela mulher, que dele tivera um filho e que caíra na vida. Esse único momento em que o leitor pensa que verá algum tipo de punição para Cassi Jones serve, na verdade, para mostrar que também a zona urbana era refúgio de infelizes.

O décimo e último capítulo se inicia com uma elipse; Clara espera por Cassi, já desconfiando de que ele não virá. A ação retrocede para que compreendamos como a situação toda "foi num galope para a desgraça"; a sedução, os enganos, a janela aberta, as suspeitas. O que na primeira Clara era atribuído ao efeito da bebida, aqui decorre simplesmente da ignorância de menina sem conhecimento do mundo, presa aos confins de sua vida suburbana, que viria a ensejar, deixando que o violeiro se 
insinuasse quarto adentro. O que ela sente não é o torpor da cerveja da primeira Clara, mas “não sei que torpor de vontade” (BARRETO, 2012, p. 269),

de ânimo, como que ela deixou de ser ela mesma, para ser uma coisa, uma boneca nas mãos dele [...] e, insensivelmente, sem brutalidade, nem violência de espécie alguma, ele a tomou para si, tomou sua única riqueza, perdendo-a para toda a vida e vexando-a, daí em diante, perante todos, sem esperança de reabilitação.

Vem neste mesmo capítulo final a certeza de que Cassi partira para São Paulo. A compreensão de sua desventura lhe chega; sofrera o abuso por ser "pobre, e além de pobre, mulata"; "sentia-se só, isolada, única na vida” (BARRETO, 2012, p. 282). A sorte trágica de Clara, determinada por sua condição racial e social inescapável, ainda será exposta na cena vexatória em que, em busca de reparação, vai à casa da família de Cassi Jones.

O local outrora fora "um simples e modesto chalet" que o pai do meliante reformara, "aumentando o imóvel, dando um aspecto de boa burguesia remediada" (BARRETO, 2012, p. 290). Levada por dona Margarida, aquela "varonil” vizinha que por vezes passava a Clara pequenos serviços e que acompanhava a mocinha em alguns passeios, confronta dona Salustiana, a mãe do modinheiro. Ao ouvir a história e o pedido de Clara para que Cassi retifique o malfeito casando-se com ela, a aristocrata dos subúrbios retorque: “Que é que você diz, sua negra?” - o chamamento é o mesmo empregado pelo rapaz que, no fim da versão de 1904, tenta violar a moça e que, na análise de Lilia Schwarcz (2017, p. 413), dá o "exemplo das continuidades da escravidão que se reinventaram na República”.

As irmãs e o pai de Cassi se juntam à cena, que descamba em desalento. O pai é tomado de profundo amargor, e uma das filhas pede à dupla que se vá.

As duas tomam o bonde, que "vinha cheio" (BARRETO, 2012, p. 294).

Olhou todos aqueles homens e mulheres... Não haveria um talvez, entre toda aquela gente de ambos os sexos, que não fosse indiferente à sua desgraça... Ora, uma mulatinha, filha de um carteiro! O que era preciso, tanto a ela como às suas iguais, era educar o caráter, revestir-se de vontade, como possuía essa varonil dona Margarida, para defender-se de Cassis e semelhantes, e bater-se contra todos os que se opusessem, por este ou aquele modo, contra a elevação dela, 
social e moralmente. Nada a fazia inferior às outras, senão o conceito geral e a covardia com que elas o admitiam...

A realidade da pobre Clara, porém, não é tão simples. Ela compreende que, não, não está só, mas que sua gente, tanto como ela, é de pouco valor. Lima Barreto emprega, na comovente frase final de seu romance, uma formulação que ecoa o sentimento do vilão em sua visita ao centro no capítulo anterior. Tanto a personagemtítulo quanto seu antagonista se veem, por esse eco linguístico, irmanados na sua condição de desajustados.

Enquanto Cassi Jones, com sua "personalidade de medíocre suburbano, de vagabundo doméstico" (BARRETO, 2012, p. 257), ficava reduzido "a quase coisa alguma", Clara - ainda um degrau abaixo, não só suburbana mas mulher, pobre e negra - , abraçando a mãe, constata: "Nós não somos nada nesta vida" (BARRETO, 2012, p. 294). 


\section{Considerações finais: o Rio partido de Lima Barreto}

Transcorrida essa viagem no tempo e espaço pela pena de Lima Barreto, por sua letra torta como as ruas de um Rio que ele viu perecer, é o momento de, numa espécie de síntese, compreender como era o Rio partido de Lima Barreto.

No primeiro capítulo, levados pela mão dos biógrafos do escritor, tentamos definir como se entrelaçam o lugar social de Afonso Henriques de Lima Barreto e os lugares em que fisicamente ele circulou e que habitou no Rio de Janeiro.

Nascido de pais mestiços e ainda bem próximos da escravidão - primeiro filho sobrevivente dos quatro que teria o casal Amália Augusta, professora, e João Henriques, tipógrafo, nascido exatos sete anos antes da Abolição, a 13 de maio de 1881 -, o escritor viveu numa espécie de interregno espacial e temporal. Sua infância foi marcada por deslocamentos vários pela cidade, causados pela tuberculose da mãe e, depois, pela sua morte. Pouco mais tarde, com um tranco violento chamado República, Afonso e seus parentes foram mandados para muito longe, para a Ilha do Governador. A mudança para um lugar isolado supôs também enorme deslocamento social para a família de João Henriques, que passou de tipógrafo protegido e empregado por um homem forte do Império a, uma vez vinda a República, funcionário das Colônias de Alienados. 47

Os encantos da ilha que por um tempo acolheram a meninice de Afonso se viram solapados novamente pela violência republicana, desta vez sob o nome de Revolta da Armada. Abandonados à própria sorte, os Lima Barretos foram sitiados pela Marinha amotinada, acontecimento marcante para a vida do jovem escolar.

Mas a vida continuou, e com ela veio a obrigação de seguir o sonho que seu pai tinha para ele. Acostumados a uma sociedade na qual "conviviam padrões de

\footnotetext{
47 Devo à professora Lilia Schwarcz duas correções feitas neste parágrafo, decorrentes de apontamentos feitos durante sua arguição, na defesa. Ela reforçou a importância de lembrar que Afonso não foi o primogênito, mas o primeiro filho sobrevivente de Amália e João Henriques, lembrando-me que a morte de Nicomedes, primogênito de facto, representaria o início da derrocada dos sonhos e expectativas do casal, além de ter deixado em Amália sequelas importantes, já mencionadas no primeiro capítulo. A professora apontou também o fato de que, aqui, eu apressadamente definira João Henriques como "tipógrafo do Império", coisa que ele não era, querendo dizer apenas dizer que ele era ligado ao regime, por trabalhar para o visconde de Ouro Preto.
} 
sociabilidade mais aristocráticos com modelos burgueses e urbanos de inserção”, os pais de Lima Barreto combinaram talento ao "favor e proteção" de padrinhos importantes, como o visconde de Ouro Preto (SCHWARCZ, 2017, p. 49). Dentro desse quadro, acreditaram que era possível ascender socialmente de maneira que as origens mestiças não se provassem mais importantes. O diploma, o grau de doutor que João Henriques não alcançara, seria o passo natural para o Afonso.

Vivendo no centro do Rio sozinho, passando necessidade, mas descobrindo a urbe, o adolescente Afonso Henriques se prepara para ingressar na Escola Politécnica. O devaneio de usar o anel de engenheiro, que de resto sempre fora mais do seu pai do que seu próprio, se vê frustrado primeiro pelas dificuldades do aluno e, depois, ceifado radicalmente pela doença de João Henriques, que enlouquece em 1902. Afonso deixa a Politécnica, pois precisa trabalhar ao ter de se fazer responsável pela manutenção do pai, dos três irmãos mais novos, da concubina de João Henriques, Prisciliana, e seus três filhos, e de Manuel de Oliveira, ex-escravo que se tornara agregado do lar dos Lima Barretos. A família passa a habitar no subúrbio de Todos os Santos, e sua morada é conhecida como "a casa do louco".

O quadro de frustrações e múltiplos deslocamentos forjou em Lima uma personalidade que se pode qualificar como excêntrica - o termo guarda a dupla conotação, física e social, que abarca a posição do escritor quanto ao quadro da época. Lima Barreto se posiciona quanto às questões de seu tempo de maneira bastante fora da norma. Condena, por exemplo, o cosmopolitismo que vicejava naquele momento em que o Rio buscava estar à altura dos padrões europeus; censura também a postura individualista, que desde o Encilhamento, em 1890, com suas promessas de enriquecimento fácil, tomara a atmosfera do Rio, fazendo da cidade a "capital do arrivismo" (SEVCENKO, 2003, pp. 36-57). Combate o beletrismo, que ele e seus amigos veem representado na figura do escritor maranhense Coelho Neto. Posicionase claramente como autor negro, denunciando a questão racial em seus escritos. Adota o anarquismo e o maximalismo, ainda que de um ponto de vista particular. Acima de tudo, defende a ideia de uma "literatura militante", cuja função seja promover a união da humanidade, a solidariedade.

O conceito de "literatura militante" é debatido ao fim do primeiro capítulo, tomando por eixo o texto "O destino da literatura". Escrito como uma palestra que o 
escritor nunca proferiu, vencido pelo álcool, vício contra o qual lutou durante toda a vida, foi publicado e se tornou seu "testamento literário".

O alcoolismo o levaria a experimentar o deslocamento extremo do isolamento no hospício, ao qual foi recolhido após graves crises, em duas ocasiões. Seria, por fim, a causa de sua morte, aos 41 anos. Ao morrer, era um homem precocemente envelhecido, aposentado após menos de 15 anos de serviço público. Quase como ironia, tendo vivido por duas décadas no subúrbio, foi enterrado, conforme seu pedido, no cemitério São João Batista, no bairro de Botafogo que ele tanto deplorou em seus escritos, considerado por ele o lar por excelência dos tipos que desprezava.

O segundo e o terceiro capítulos se debruçaram respectivamente sobre centro e subúrbio na obra de Lima Barreto.

Em 1903, enquanto Lima começa sua vida pendular, morando no subúrbio de Todos os Santos e trabalhando como amanuense da Secretaria da Guerra, no centro da cidade, o Rio também passa por enormes transformações, com o conjunto de reformas urbanas comandado pelo governo federal sob Rodrigues Alves e pela administração municipal sob Pereira Passos.

No segundo capítulo, além de fazer um breve repasse que buscasse delinear a extensão das reformas operadas no centro do Rio de Janeiro, o principal foi entendêlas do ponto de vista ideológico. Para isso, nos apoiamos fundamentalmente nos conceitos de civilização e progresso, conforme estudados por André Nunes de Azevedo (2017). A ideia imperial de uma civilização de lenta evolução, que progredisse gradualmente até seu ápice, sem solavancos e golpes, se choca com a concepção republicana - defendida, por um lado, pelo Clube dos Engenheiros, e, por outro, pelos cafeicultores paulistas - de progresso material como um valor autônomo e superior aos da civilização. Segundo Azevedo, a reforma urbana promovida pela União, cujo objetivo principal eram as melhorias do defasado porto do Rio, se inclinou pelo viés do progresso material, enquanto a reforma planejada por Pereira Passos, um exfuncionário do Império, se pautou pela noção de civilização como um objetivo maior. As duas convicções se materializam no espaço físico da avenida Central - hoje avenida Rio Branco. A Avenida, como era simplesmente conhecida, foi pensada como um eixo de escoamento dos produtos que chegavam e saíam pelo porto, no âmbito da reforma 
federal, mas acabou absorvida pelo plano municipal como um espaço para o exercício civilizatório.

Enquanto tudo isso acontecia no centro, Lima Barreto produzia seus escritos. Nos primeiros anos, entre 1903 e 1905, a maior parte de sua produção é o Diário íntimo - as notas de toda a vida foram coligidas em livro por Francisco de Assis Barbosa, seu primeiro biógrafo, e são uma chave fundamental para compreender a visão de mundo de Lima e seguir o rastro de seus escritos, pois ali estão recolhidos também rascunhos de futuras obras, como Clara dos Anjos.

Sua estreia num jornal se dá de forma anônima; contratado para escrever uma reportagem seriada sobre os subterrâneos do morro do Castelo, que estavam sendo escavados como parte das obras de construção da avenida Central, Lima envereda por um folhetim fantasioso. A essa altura, escritores seus contemporâneos que já assinavam seu nome nos jornais, como Olavo Bilac, louvavam as "picaretas regeneradoras" (BILAC, O. "Kosmos”, mar.1904), que botavam abaixo o Rio Antigo, torto, colonial, que não se prestava à modernidade que a cidade queria alcançar.

Desde sempre em desajuste com o meio, funda em 1907 a revista Floreal. A aventura que empreende com um grupo de amigos não vai longe, fica em quatro números. Mas Lima entenderia que as revistas, sobretudo as pequenas, são o canal que prefere para sua expressão. Até porque sua estreia em livro, em 1909, com Recordações de Isaías Caminha, soterraria qualquer caminho na grande imprensa, que ele achincalha no romance sobre um jovem provinciano que quer ser doutor no Rio, acaba contínuo de um jornal e por fim consegue um emprego público.

Sobre as mudanças que seu Rio, seu "tolerante Rio, bom e relaxado, belo e sujo, esquisito e harmônico" (BARRETO, 1961, p. 92) enfrentaria, Lima escreveria um bocado no diário. Mas, principalmente, faria uma elegia à cidade em Vida e Morte de M. J. Gonzaga de Sá.

O romance, escrito no começo de sua trajetória - as primeiras anotações, segundo Francisco de Assis Barbosa, datariam de 1906 (BARRETO, 1961, p. 121) - foi o último que ele publicou em vida. Talvez porque nele faça uma crítica ao funcionalismo público, tenha preferido guardá-lo até depois de sua aposentadoria. 
Esse livro que entrelaça a biografia do personagem-título, um velho amanuense branco, e a história da cidade que se esvai é também a história do narrador, Augusto Machado - um jovem amanuense negro. Com Gonzaga de Sá, Machado aprende a se ver, em suas origens, como um legítimo habitante do Rio.

Como contraponto ao último romance da vida de Lima Barreto, lemos também o primeiro - Recordações do escrivão Isaías Caminha. R.J. Oakley defende que Isaías Caminha e Gonzaga de Sá são "heróis intelectuais" do tipo contemplativo - aquele que, "frequentemente inadaptado e às voltas com a sociedade circundante, sente a premente necessidade de agir, enquanto simultaneamente receia que agir seja um gesto fútil" (OAKLEY, 2011, pp. 86). No entanto o que constatamos é que as contemplações a que se dão sobre a cidade são de cunho totalmente diferente.

Lima Barreto inscreve seu Isaías, interiorano recém-chegado ao Rio, no rol daqueles personagens dos romances franceses que deixam a província tacanha para se perderem na metrópole dissoluta (AZEVEDO, 2006, pp. 21-2). É uma espécie de Lucien Chardon das Ilusões perdidas de Balzac, deixando-se levar e corromper pela vida da cidade grande.

Por outro lado, a atitude contemplativa de Gonzaga de Sá parte de uma relação completamente distinta com o meio. Ele está em seu elemento desde o berço e preza sua relação com a cidade de cujos fundadores descende - Estácio de Sá e Mem de Sá. Quando vai pelas ruas, Gonzaga de Sá não se deixa levar pela multidão como Isaías Caminha; ele vaga, observando as ruas e os prédios; contempla o presente através do passado, contrapondo um tempo a outro.

Seguindo alguns temas sugeridos pela leitura de Vida e Morte de M. J. Gonzaga de Sá, nos debruçamos também sobre a crítica que Lima Barreto faz, em crônicas, à relação das gentes da República com o meio natural da cidade. Os aterros, a busca por expandir-se "sob o açoite constante dos impiedosos ventos do sul”, tendo ali uma "baía abrigadíssima" (BARRETO, 2004, pp. 527-9, vol.1), a derrubada de árvores ancestrais ou o desleixo com as palmeiras do imperial Jardim Botânico comparecem nesses escritos para a imprensa.

Com as leituras, pudemos concluir que Lima Barreto era um homem mais pautado por um ideal civilizatório à moda do Império, vendo a civilização como uma 
finalidade comum que se alcançaria gradativamente - mas, e isso é muito, importante, de maneira adequada ao nosso país, sem concessões ao cosmopolitismo. O éthos republicano que valorizava o progresso material e individual se opõe à sua ideia de um mundo em harmonia solidária.

O terceiro e último capítulo traz as considerações de Lima Barreto sobre o subúrbio. Estas se fazem mais frequentes conforme sua vida fica mais restrita a Todos os Santos, a partir da aposentadoria. Um pouco antes, em 1917, sentindo a saúde declinar, ele se dispõe a organizar a sua biblioteca, que apelidara Limana, na Vila Quilombo, como chamava a última casa que a família habitou em Todos os Santos. Entre os escritos que organizou e deixou na biblioteca, estava Clara dos Anjos. A leitura desse romance dá o fio condutor para este capítulo.

Para falar dos subúrbios em Lima Barreto, porém, era preciso entender quanto eles sofreram as consequências da reformulação do centro da cidade. O ano de 1904, quando Lima começa a trabalhar nos primeiros esboços para Clara dos Anjos, é o "ano das demolições”, o verdadeiro "bota-abaixo” do Velho Rio.

A situação de moradia - que já era um problema de décadas, sendo o centro pontuado por habitações precárias dos que ali se acomodavam para estar perto das fontes de renda - se fazia a cada dia mais complexa após as desapropriações, particularmente cruéis com a imensa massa de não proprietários, que se viam de uma hora para a outra no olho da rua.

Os que puderam, mudaram-se para os subúrbios ao norte, construídos ao longo da Estrada de Ferro Central do Brasil. É nesses subúrbios que se passa Clara dos Anjos em sua versão final, publicada já depois da morte do autor, entre 1923 e 1924, como folhetim, na revista Mundo Literário.

Um cotejo com as versões anteriores - as notas no diário e uma versão em conto, publicada em Histórias e sonhos (1920) - nos permite ver como a trama e a visão das personagens se modifica quanto mais Lima passa a de fato viver o cotidiano do subúrbio. O enredo básico, acerca de uma jovem moça mulata deflorada e abandonada por um rapaz branco, não se modifica essencialmente entre as versões publicadas. Em nenhuma delas, há final feliz para quem está nos degraus mais baixos da escada, mesmo no subúrbio. 
Porque - e isso fica claro no romance publicado em folhetim - não há um só subúrbio, mas vários. As diferenças entre os suburbanos pretensamente aristocráticos, como o violador Cassi Jones, e os remediados, como Clara e sua família, reproduzem em microescala os contrastes sociais mais amplos.

Mas só até certo ponto. Com o auxílio novamente das crônicas, que complementam as ideias do romance e mostram o poder de observação de Lima Barreto sobre seus arredores, desnudamos o jogo de aparências no qual, ao final, a vantagem do suburbano branco é ser "quase coisa alguma", num meio em que os que são como a pobre Clara, afinal, "não são nada".

A literatura de Lima Barreto não nos fala de redenção.

Em sua vida e em sua obra, ele buscou defender seus ideais; buscou promover a necessidade de união entre os homens, entre os povos, a ideia de nação, de raça, de diferença social se dissolvendo na noção de solidariedade. Mas o real foi cruel, e não havia como ignorá-lo.

O que pôde um homem negro, habitante das bordas da cidade; funcionário público, mas não dos altos escalões; um intelectual forjado na quietude de um quarto no subúrbio; um homem crítico dos rumos do poder, morto aos 41 anos, vitimado pelo alcoolismo no qual buscou mitigar os efeitos da situação opressora que vivia? O que pôde Lima Barreto contra as opressões que ele viu e viveu em seu tempo?

Se pensarmos como os práticos e cínicos arrivistas da República, buscando o progresso material acima de qualquer coisa, diremos que nada. Diremos que nem o vimos passar por aqui.

Como, no entanto, mais à moda do próprio Lima, persistiremos sonhando com os pés e os olhos fixos na realidade, melancolicamente diremos que talvez não seja possível mudar nada, mas é necessário saber que há o que mudar.

Muito pouco mudou no Rio e no Brasil, nos quase cem anos que nos separam do tempo de Lima Barreto. Que possamos fazer do que ele enxergou um leme com o qual seguir adiante. 


\section{Referências ${ }^{48}$}

\section{Obras de Lima Barreto}

BARRETO, Lima. $\quad$ Clara dos Anjos. São Paulo: Penguin \& Companhia das Letras, 2012.

Contos completos (org. Lilia Moritz Schwarcz). São Paulo: Companhia das Letras, 2010.

Diário do hospício e O cemitério dos vivos. São Paulo: Companhia das Letras, 2017.

Diário íntimo. 2.ed. São Paulo: Brasiliense, 1961.

Impressões de leitura e outros textos críticos (org. Beatriz Resende). São Paulo: Penguin \& Companhia das Letras, 2017a.

O subterrâneo do morro do Castelo. 4.ed. Rio de Janeiro: Dantes, $2017 \mathrm{c}$.

Recordações do escrivão Isaías Caminha. São Paulo: Penguin \& Companhia das Letras, 2017d.

Sátiras e outras subversões: textos inéditos. Org. Felipe Botelho Corrêa. São Paulo: Penguin \& Companhia das Letras, 2016. 2004, 2 vol.

Toda crônica. Org. Beatriz Resende e Rachel Valença. Rio de Janeiro: Agir,

Triste fim de Policarpo Quaresma. São Paulo: Penguin \& Companhia das Letras, 2011.

Vida e obra de M. J. Gonzaga de Sá. Cotia: Ateliê Editorial, $2017 \mathrm{e}$.

\section{Obras de outros autores}

AZEVEDO, André Nunes de. A grande reforma urbana do Rio de Janeiro: Pereira

Passos, Rodrigues Alves e as ideias de civilização e progresso. Rio de Janeiro: Ed.

PUC-Rio e Mauad, 2017.

AZEVEDO, Ricardo Marques de. Metrópole: abstração. São Paulo: Perspectiva, 2006

BARBOSA, Francisco de Assis. A vida de Lima Barreto (1881-1922). Belo Horizonte:

Autêntica, 2017, 11. ed.

BENCHIMOL, Jaime Larry. Pereira Passos, um Haussmann tropical: a renovação

urbana da cidade do Rio de Janeiro. Rio de Janeiro: Secretaria Municipal de Cultura, 1992.

BOTELHO, Denilson. A pátria que quisera ter era um mito: o Rio de Janeiro e a militância literária de Lima Barreto. Rio de Janeiro: Prefeitura do Rio, 2002. Coleção Biblioteca Carioca, v. 44.

${ }^{48}$ De acordo com a Associação Brasileira de Normas Técnicas (ABNT NBR 6023). 
BRENNA, Giovanna Rosso Del. O Rio de Janeiro de Pereira Passos. Uma cidade em questão II. Rio de Janeiro: Index, 1985.

CASTRO, Ruy. Metrópole à beira-mar: O Rio moderno dos anos 20. São Paulo: Companhia das Letras, 2019.

FERNANDES, Nelson da Nóbrega. O rapto ideológico da categoria subúrbio: Rio de Janeiro 1858-1945. Rio de Janeiro: Apicuri, 2015.

FIGUEIREDO, Carmem Lúcia Negreiros de. Lima Barreto e o fim do sonho republicano. Rio de Janeiro: Tempo Brasileiro, 1995.

GORELIK, Adrián. Miradas sobre Buenos Aires: historia cultural y crítica urbana. Buenos Aires: Siglo XXI, 2004.

JOÃO, C.R.V; LENZ, M.I.; BEZERRA R.Z. Tão importante, tão esquecido: o bairro da Misericórdia. Rio de Janeiro: Museu Histórico Nacional, 2016.

MEYER, Marlyse. Folhetim: uma história. 2 ed. São Paulo: Companhia das Letras, 2005.

OAKLEY, R.J. Lima Barreto e o destino da literatura. São Paulo: Unesp, 2011. ed. eletrônica

PIMENTEL, Luz Aurora. Metaphoric Narration. Paranarrative Dimensions in A la recherche du temps perdu. Toronto/Buffalo/London: University of Toronto Press, 1990.

PRADO, Antonio Arnoni . Lima Barreto: o crítico e a crise. Rio de Janeiro: Cátedra; Brasília: INL, 1976.

RAMA, Ángel. A cidade das letras. Trad. Emir Sader. São Paulo: Brasiliense, 1985.

RESENDE, Beatriz. Lima Barreto e o Rio de Janeiro em fragmentos. Rio de Janeiro: Autêntica, 2016.

SCHWARCZ, Lilia Moritz. Lima Barreto: triste visionário. São Paulo: Companhia das Letras, 2017.

SEVCENKO, Nicolau. A Revolta da Vacina: mentes insanas em corpos rebeldes. São Paulo: Cosac Naify, 2013, 1.ed. eletrônica.

Literatura como missão: tensões sociais e criação cultural na Primeira República. 2 ed. São Paulo: Companhia das Letras, 2003.

SÜSSEKIND, Flora. Cinematógrafo de letras. Literatura, técnica e modernização no Brasil. São Paulo: Companhia das Letras, 1987.

VENTURA, Zuenir. Cidade partida. São Paulo: Companhia das Letras, 1994.

\section{Artigos e ensaios}

BENCHIMOL, Jaime Larry. A modernização do Rio de Janeiro. In: BRENNA, Giovanna Rosso Del. $O$ Rio de Janeiro de Pereira Passos. Uma cidade em questão II. Rio de Janeiro: Index, 1985, pp. 599-611.

CANDIDO, Antonio. Os olhos, a barca e o espelho. In: A educação pela noite e outros ensaios. São Paulo: Ática, 2000, 3. ed., pp 39-50.

CARVALHO, Maria Alice Rezende de. Crepúsculo da Ouvidor. In: GORELIK, A. e PEIXOTO, F.A. (org.). Cidades sul-americanas como arenas culturais. São Paulo: Edições Sesc, 2019, pp. 25-36.

CASTRO, Ana Claudia Veiga de. Figurações da cidade: um olhar para a literatura como fonte da história urbana. An. mus. paul.,. São Paulo, v. 24, n.3, pp. 99-120, dez. 2016, s.n. Disponível em http://www.scielo.br/scielo.php?script=sci_arttext\&pid=So10147142016000300099\&lng=en\&nrm=iso. Acesso em 12 fev.2020.

CHIAVARI, Maria Pace. As transformações urbanas do século XIX. In: BRENNA, Giovanna Rosso Del. 
O Rio de Janeiro de Pereira Passos. Uma cidade em questão II. Rio de Janeiro: Index, 1985, pp.569-93.

COELHO, Frederico. Introdução. Lima, poeira e sal grosso. In: BARRETO, Lima. O subterrâneo do morro do Castelo. 4.ed. Rio de Janeiro: Dantes, 2017c, pp. 9-15.

CORRÊA, Felipe Botelho. Introdução. In: BARRETO, Lima. Sátiras e outras subversões: textos inéditos. Org. Felipe Botelho Corrêa. São Paulo: Companhia das Letras, 2016, pp 11-75.

COSTA LIMA, Luiz. História. Ficção. Literatura. Uma breve apresentação. Eutomia: Revista Online de Literatura e Linguística. Recife, v. 1, n. 1, pp. 167-76. jul. 2008. Disponível em: https://periodicos.ufpe.br/revistas/EUTOMIA/article/view/1976/1542. Acesso em 8 fev. 2020

LEME, Maria Cristina da Silva (org.). A formação do pensamento urbanístico no Brasil, 1895-1965. In: . Urbanismo no Brasil 1895-1965. São Paulo: Fupam e Studio Nobel, 1999, pp. 20-38.

LOEWEN, Andrea Buchidid; AZEVEDO, Ricardo Marques de. Roma e as capitais: o mito e o plano. Oculum Ensaios: Revista de Arquitetura e Urbanismo. Campinas, n. ja/ju 2006, p. 22-33.

MARINS, Paulo César Garcez. Habitação e vizinhança: limites da privacidade no surgimento das metrópoles brasileiras. In: SEVCENKO, Nicolau (org.). História da vida privada no Brasil: República: da belle époque à era do rádio. São Paulo: Companhia das Letras, 1998, pp. 131-214.

RESENDE, Beatriz. Apresentação: em defesa de Clara dos Anjos. In: Barreto, Lima. Clara dos Anjos. São Paulo: Penguin \& Companhia das Letras, 2012, pp. 9-24.

Introdução. In: BARRETO, Lima. Impressões de leitura e outros textos críticos (org. Beatriz Resende). São Paulo: Penguin \& Companhia das Letras, 2017a, pp 29-42.

Sonhos e mágoas de um povo. In: Toda crônica. Org. Beatriz Resende e Rachel Valença. Rio de Janeiro: Agir, 2004, vol.1, pp 9-23.

REZENDE, Vera F. Evolução da produção urbanística na cidade do Rio de Janeiro, 1900-1950-1965. In: LEME, Maria Cristina da Silva (org.). Urbanismo no Brasil 1895-1965. São Paulo: Fupam e Studio Nobel, 1999, pp. 39-70.

SCHEFFEL, Marcos. Vida e Morte de M.J. Gonzaga de Sá - Possibilidades éticas e estéticas do romance moderno brasileiro. In: BARRETO, Lima, Vida e obra de M. J. Gonzaga de Sá. Cotia: Ateliê Editorial, 2017e, pp. 9-43.

SEVCENKO, Nicolau. A capital irradiante: técnica, ritmos e ritos do Rio. In: , Nicolau (org.). História da vida privada no Brasil: República: da Belle Époque à Era do Rádio. São Paulo: Companhia das Letras, 1998, pp. 513-619.

SILVA, Luara dos Santos. Negro, intelectual e professor: Hemetério José dos Santos e as questões raciais de seu tempo (1875 - 1920). In: Anais do XVI Encontro Regional de História da Anpuh-Rio: Saberes e práticas científicas Rio de Janeiro, 2014. Disponível em: http://www.encontro2014.rj.anpuh.org/resources/anais/28/1400476138_ARQUIVO_textoAnpuhfina l.pdf. Acesso em 27.fev.20.

\section{Artigos em periódicos}

BACKHEUSER, Everardo. Onde moram os pobres. Renascença, Rio de Janeiro, mar.1905, ano II, n.13, pp. 89-94. Disponível em http://memoria.bn.br/DocReader/138622/730. Acesso em 28.fev.2020.

BILAC, Olavo. Crônica. Kosmos, Rio de Janeiro, mar.1904, s.n. Disponível em http://memoria.bn.br/DocReader/146420/109. Acesso em 24.fev.2020.

BILAC, Olavo. Crônica. Kosmos, Rio de Janeiro, nov.1904, s.n.. Disponível em http://memoria.bn.br/DocReader/146420/542. Acesso em 23.fev.2020

LAET, Carlos de. Poeira e micróbios. Jornal do Brasil, Rio de Janeiro, 24 de agosto de 1904, Primeiro 
caderno, p. 1. Disponível em http://memoria.bn.br/DocReader/030015_02/14554. Acesso em 28.fev.20

MORALES DE LOS RIOS, A. Os novos cais. O País, Rio de Janeiro, 1.jun.1903. Primeiro caderno, pp 12. Disponível em http://memoria.bn.br/DocReader/178691_03/6065. Acesso em 23.fev.2020

VIDAL, Gil. O novo prefeito. Correio da Manhã, Rio de Janeiro, 30.dez.1902. Primeiro caderno, p.1. Disponível em http://memoria.bn.br/DocReader/089842_01/3031. Acesso em 22.fev.2020 